ESTUDOS DE CULTURA MATERIAL 


\title{
Ornato e despojamento no mundo fabril
}

\author{
Telma de Barros Correia ${ }^{1}$
}

RESUMO: $\bigcirc$ artigo investiga algumas das tendências da arquitetura gerada por fábricas galpões industriais, moradias, igrejas, escolas, clubes etc. -, erguida no Brasil entre as duas últimas décadas do século XIX e as primeiras do XX. Apoia-se em amplo inventário, como base para um esforço de análise que se propõe a identificar os temas e usos predominantes dos ornatos aplicados a construções geradas por fábricas, as referências historicistas mobilizadas e eventuais rupturas de signos arquitetônicos tipológicos, e, no limite, a abolição de ornatos e dos referidos signos. Assim, de um lado, trata da penetração da linguagem eclética nessas construções, investigando o repertório formal utilizado em diferentes tipologias. De outro, trata da simultânea difusão de uma estética tipicamente fabril, fundamentada em noções de economia, eficiência, utilidade e funcionalidade. Mostra como tais noções se expressam ora em uma simplificação ou ausência de ornatos, ora no uso de ornatos cujos temas remetem ao mundo das máquinas; às vezes, no distanciamento ou abandono de signos arquitetônicos tipológicos consagrados; ou, ainda, no emprego de materiais produzidos industrialmente e que se difundiram a partir, sobretudo, da arquitetura de fábricas.

PAlAVRAS-ChAVE: Arquitetura Fabril. Vilas Operárias. Ecletismo. Historicismo. Ornato. Despojamento.

ABSTRACT: The article examines some aspects of the architecture created for factories - warehouses, houses, churches, schools, clubs etc. -, built in Brazil between the two last decades of the nineteenth century and early of the twentieth century. The research relies on extensive inventory, the basis on which an analysis effort is realized that aims to identify the themes and predominant use of ornament applied to constructions produced by factories, the historicist references mobilized and eventual disruption of typological architectural signs, and, ultimately, the elimination of ornament and of those signs. Therefore, on one side, it deals with the penetration of the eclectic language in these buildings, by examining the formal repertoire used in different typologies. On the other side, it deals with simultaneous diffusion of a typical manufacturing aesthetic, based on notions of economy, efficiency, utility and functionality. It shows how such notions are expressed in either a simplification or the lack of ornament, sometimes in the use of ornament whose themes relate to the world of machines, sometimes in the detachment or abandonment of embodied architectural
1. Docente do Instituto de Arquitetura e Urbanismo da Universidade de São Paulo-São Carlos. E-mail: <tcorreia@sc.usp.br>. 
2. Cf. Carl Schorske (2000, p. 15).

3. Ibidem. typological signs, or even the use of industrially produced materials that have spread from mainly the architecture of factories.

KEYWORDS: Factory Architecture. Working-class Sections. Eclecticism. Historicism. Ornament. Bareness.

A arquitetura no mundo industrial

Entre as profundas alterações associadas à difusão da indústria moderna e à ascensão da burguesia industrial no Brasil, a partir do século XIX, situam-se mudanças radicais na forma de construir, com a introdução de novos materiais e técnicas construtivas, propagação de novos programas e tipologias, e difusão de novas linguagens arquitetônicas. Curiosamente, em um primeiro momento, essas novas linguagens se encaminham em duas direções opostas. De um lado, verificam-se tendências à apropriação de estilos do passado e à adoção de ornatos em profusão - duas das vertentes do que se convencionou chamar ecletismo. De outro, difunde-se uma tendência oposta, de inovação - em termos de materiais, de técnicas e também de linguagem -, em edificações que, além de desprovidas de referências historicistas, operam uma renovação ou abolição dos ornatos.

Na arquitetura, o historicismo reflete a dificuldade, da burguesia do século XIX, em conquistar a legitimidade do gosto. Conforme mostra Schorske, o historicismo, na cultura, constituiu um "modo de enfrentar a modernização invocando recursos do passado"2. Na arquitetura, conforme o autor, a apropriação dos estilos do passado em novos programas - estações ferroviárias, bancos etc. - visou "dar peso e linhagem às construções modernas [...]. As culturas do passado forneceram a roupagem decente para vestir a nudez da utilidade moderna" ${ }^{3}$. Em uma sociedade comandada por noções de economia e funcionalidade, trata-se de mascarar a extrema simplificação da linguagem e o empobrecimento da forma.

historicismo na arquitetura revela-se, ainda, como um aspecto da "nostalgia aristocrática" de uma burguesia em ascensão, bastante dividida entre os valores que a fundamentam e legitimam como classe e seu fascínio pela aristocracia. Expressões dessa ambiguidade se fazem presente em vários aspectos da cultura burguesa, desde o empenho em copiar modos da aristocracia amplamente criticados e ridicularizados por escritores como Balzac e Molière -, até a referência à casa aristocrática como modelo de moradia - desde que devidamente mediada por cálculos econômicos. Assim, Balzac interpretou a arquitetura promovida pela burguesia francesa na década de 1830 como expressão do espírito falseador que atribui à classe e como evidência do gosto pelo simulacro que preside o mundo burguês. Trata-se, para o autor, de mais uma expressão do empenho burguês em imitar a nobreza. Aparentando uma dimensão maior do que a real e ostentando um luxo extravagante, as casas burguesas reelaboram e interpretam, segundo os valores dessa classe, a moradia da antiga nobreza: 
Os estilos são empregados confusamente. Como não existe mais corte, nem nobreza para dar o tom, não se vê nenhuma harmonia nas produções da arte. Por sua vez, nunca a arquitetura descobriu tão numerosos recursos econômicos para macaquear o verdadeiro e o sólido, nem desenvolveu tanta ciência, tanto gênio nas distribuições. Oferecei a um artista a orla de um jardim de um velho palácio demolido, e ele vos construirá um pequeno Louvre, abarrotado de ornamentos; nele encontrareis um pátio, cocheiras e, se fizerdes questão, também um jardim; no interior ele acumulará tantas saletas e tantos corredores, saberá tão bem enganar a vista, que vos sentireis à vontade ${ }^{4}$.

Descrevendo os artifícios empregados em uma dessas casas para aparentar uma dimensão superior à real, Balzac refere-se a trepadeiras dispostas em pórticos (para ocultar muros) e a uma "infinidade de ninharias" que ornam o boudoir da proprietária.

Da mesma forma que os interiores, as fachadas de moradias, fábricas e prédios de usos diversos surgem, com frequência, repletas de ornatos. Uma das expressões do ecletismo, tal profusão de elementos decorativos tornou-se possível pela produção - correlata à difusão da grande indústria - de materiais de construção (grades, lambrequins, estátuas, compoteiras etc.) em larga escala e segundo técnicas modernas.

Entretanto, os imperativos do mundo burguês também encontrariam uma expressão arquitetônica que testemunhasse com maior fidelidade seus fundamentos. Inicialmente restrita a construções utilitárias e de menor destaque, mas que paulatinamente se tornaria hegemônica (sobretudo nas construções erguidas pela indústria), difundiu-se uma arquitetura despojada de ornatos, restrita aos seus elementos construtivos essenciais, e/ou erguida com materiais - como o tijolo aparente e o ferro - produzidos industrialmente e que se difundiram a partir, sobretudo, da arquitetura de fábricas. Com ela se propaga uma estética tipicamente fabril, fundamentada em noções de economia, eficiência, utilidade e funcionalidade. Tal linguagem, além de ter se expressado através de materiais industrializados e da simplificação ou ausência de ornatos, encontrou expressão também - embora de forma mais restrita - no uso de ornatos cujos temas remetem ao mundo das máquinas.

Aqui, tentamos mostrar parte de um esforço, mais amplo, de análise da arquitetura gerada por fábricas no Brasil, onde investigamos suas diferentes expressões arquitetônicas e urbanísticas: compromissos com a arquitetura do período colonial ou com a linguagem clássica; vínculos com a estética do pitoresco; filiação ao estilo neocolonial, ao Art Déco ou ao estilo internacional de arquitetura moderna, tendências que são tema de outros trabalhos já publicados 5 .

Em meio a esta variedade de expressões formais, aqui tratamos de duas das vertentes que, no Brasil, manifestam-se simultaneamente entre as duas últimas décadas do século XIX e as primeiras do XX, presentes na arquitetura gerada por fábricas - galpões industriais, moradias, igrejas, escolas, clubes etc. Uma delas é a de cunho historicista, pautada no uso profuso de ornatos, enquanto a outra inova em materiais, técnicas e linguagem, e caminha no sentido de reelaborar, restringir e, no limite, abolir o ornato.
4. Cf. Honoré de Balzac (1989, p. 443).

5. Ver Telma de Barros Correia $(2003 ; 2006 ; 2008 ; 2009$; 2010; 2011) 
Aqui, gostaríamos de ressaltar que a questão do ornato e das referências historicistas - em termos de ocorrências, formas e ausências - não é tratada como chave única de leitura da arquitetura industrial brasileira, mas como um viés possível, e útil, de análise desta arquitetura, no momento em questão. A opção de tratar as duas tendências em um mesmo artigo visa explorar o lugar complexo ocupado, pelo ornato e pelos signos arquitetônicos, na arquitetura industrial brasileira desse período.

Ao eleger esse tema como eixo de análise, o interesse é evidenciar como essa arquitetura deles se apropriou, e como seu lugar foi sendo paulatinamente restrito e tendendo a ser abolidos quando a lógica da eficiência e da economia se impôs na produção desta arquitetura.

Para tanto, foi feito um inventário amplo da arquitetura industrial brasileira, incluindo uma descrição dos exemplares tratados - etapas consideradas imprescindíveis para a análise, especialmente em se tratando de um tema pouco conhecido e estudado, como este. As descrições variam, podendo ser sucintas ou mais detalhadas, enquanto a análise realizada ora é mais panorâmica, ora se detém em um caso investigado com mais atenção. Os casos da Vila Maria Zélia e de Rio Tinto são exemplos que receberam descrições e análises mais aprofundadas. A opção por um ou outro procedimento está atrelada, sobretudo, a uma avaliação da especificidade e relevância arquitetônica do objeto tratado.

Interessa, aqui, indicar tendências gerais e especificidades presentes na arquitetura fabril. Com base no inventário e na descrição, o esforço de análise propõe-se a identificar os temas e usos predominantes dos ornatos aplicados a construções geradas por fábricas, as referências historicistas mobilizadas, e as eventuais rupturas de signos arquitetônicos tipológicos consagrados e, no limite, a abolição de ornatos e dos referidos signos.

Ecletismo e indústria

Em casas, igrejas, escolas e instalações industriais pertencentes a fábricas, vilas operárias e núcleos fabris erguidos entre as duas últimas décadas do século XIX e as primeiras do XX é possível localizar exemplares de arquitetura com fachadas recobertas por decoração de viés eclético. A noção de racionalidade que rege o mundo fabril não o impediu de se deixar contaminar pela profusão de ornatos, que constitui uma das expressões externas da arquitetura eclética. Embora geralmente despojados e econômicos - se comparados aos de construções vinculadas a outras atividades, como as de comércio e serviços, por exemplo - a indústria, em suas construções, não deixou de lançar mão de motivos do amplo repertório ornamental eclético que, além de recuperar princípios de composição (simetria, ênfase no acesso principal etc.) e elementos da linguagem clássica (pilastras, frontões, cornijas etc.), acrescentou às composições de fachadas uma ampla gama de motivos decorativos, que incluíam compoteiras, 
esculturas, volutas e apliques sobre alvenaria - fazendo referências à natureza (flores, conchas etc.) ou seguindo formas geométricas.

A inspiração em modelos do passado, outra característica da arquitetura eclética, foi amplamente adotada pela indústria. Nas vilas e núcleos fabris, coerente com as tendências do chamado "ecletismo tipológico", observa-se uma tendência, nas casas, de haver frequentes recorrências a motivos da linguagem clássica - enquanto as igrejas remetem, sobretudo, ao românico e ao gótico ${ }^{6}$.

Em Jundiaí, em casas da vila operária da Fábrica São Bento, o vocabulário clássico se expressa na composição da fachada - com cunhal e pilastra rusticados, entablamento e platibanda. Nela, a linguagem eclética se insinua na forma da cercadura das janelas e nos motivos inspirados em conchas introduzidos sobre a platibanda (Figura 1).

Em alguns casos, moradias geminadas semelhantes (dotadas de pilastras, entablamento, platibanda e cercaduras em torno dos vãos) têm, sobre as molduras e na platibanda, apliques decorativos cujos motivos são volutas ou arranjos florais. Exemplos nesse sentido são as vilas operárias da Fábrica São Brás (Salvador) e da Companhia Fluminense (Niterói) (Figura 2).

A platibanda é, frequentemente, o elemento de destaque na composição das fachadas das casas. É nela que - sobretudo nos modelos de casas mais simples, geminadas ou em renque - os ornatos, geralmente escassos, se concentram; ou é sobre ela que são dispostos os elementos decorativos mais expressivos da composição. Nesse sentido são exemplos as vilas operárias: da

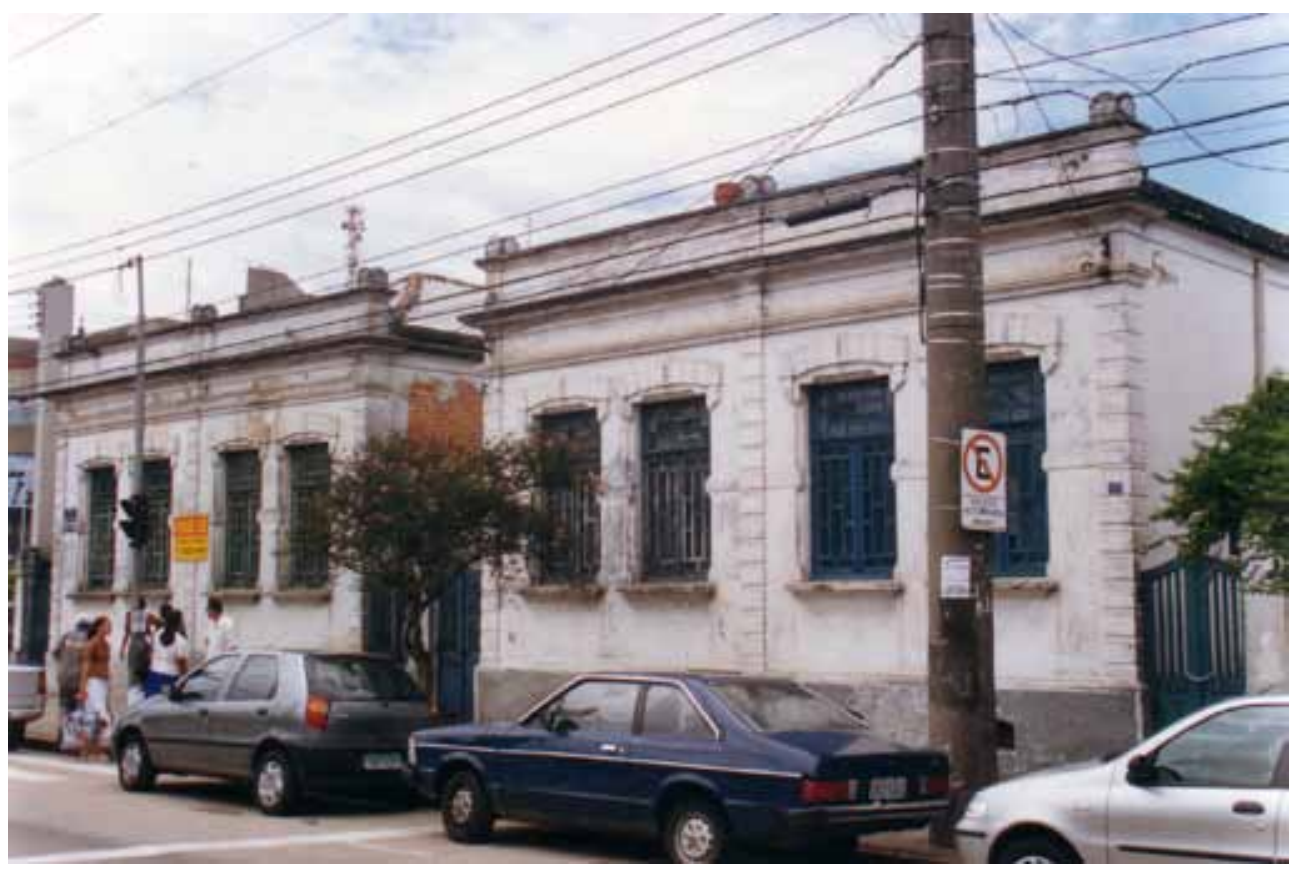

Figura 1 - Vila operária da Fábrica São Bento, em Jundiaí (SP). Fotografia de Philip Gunn, 2002.
6. Claude Mignot aponta duas vertentes no ecletismo. Em uma delas, identificada como "ecletismo sintético", a arquitetura recorre à experiência arquitetônica do passado, no sentido de combinar, de maneira nova, os princípios, soluções e motivos de diferentes períodos. Em outra, que denomina "ecletismo tipológico", dependendo do caráter que deseja imprimir à construção,o arquiteto busca um ou outro estilo ou modelo do passado, adaptando-o às necessidades do presente.Assim, estabeleceu-se uma vinculação entre usos e estilos: acreditava-se que a linguagem clássica era a mais adaptada para prédios públicos - repartições, museus, tribunais etc. -, enquanto os estilos gótico, românico ou bizantino cabiam a igrejas. Os prédios residenciais também recorriam, com frequência, à linguagem clássica. A arquitetura árabe era julgada particularmente apropriada para prédios voltados a atividades recreativas. Mercados, pavilhões de exposição e prédios fabris eram construídos adotando, de preferência, formas inovadoras, associadas ao uso de estruturas de ferro, combinado a amplos vãos envidraçados A ideia de que o tratamento formal de um prédio deveria depender de seu uso é algo presente na estética clássica e determinante na escolha da ordem a ser adotada. No ecletismo, o mesmo critério foi aplicado para escolha do estilo, para que pudesse expressar a forma julgada mais apropriada ao "caráter do prédio". Dependendo do uso, conferia-se ao prédio severidade e sobriedade, ou cor e alegria; ver Claude Mignot (1994). 


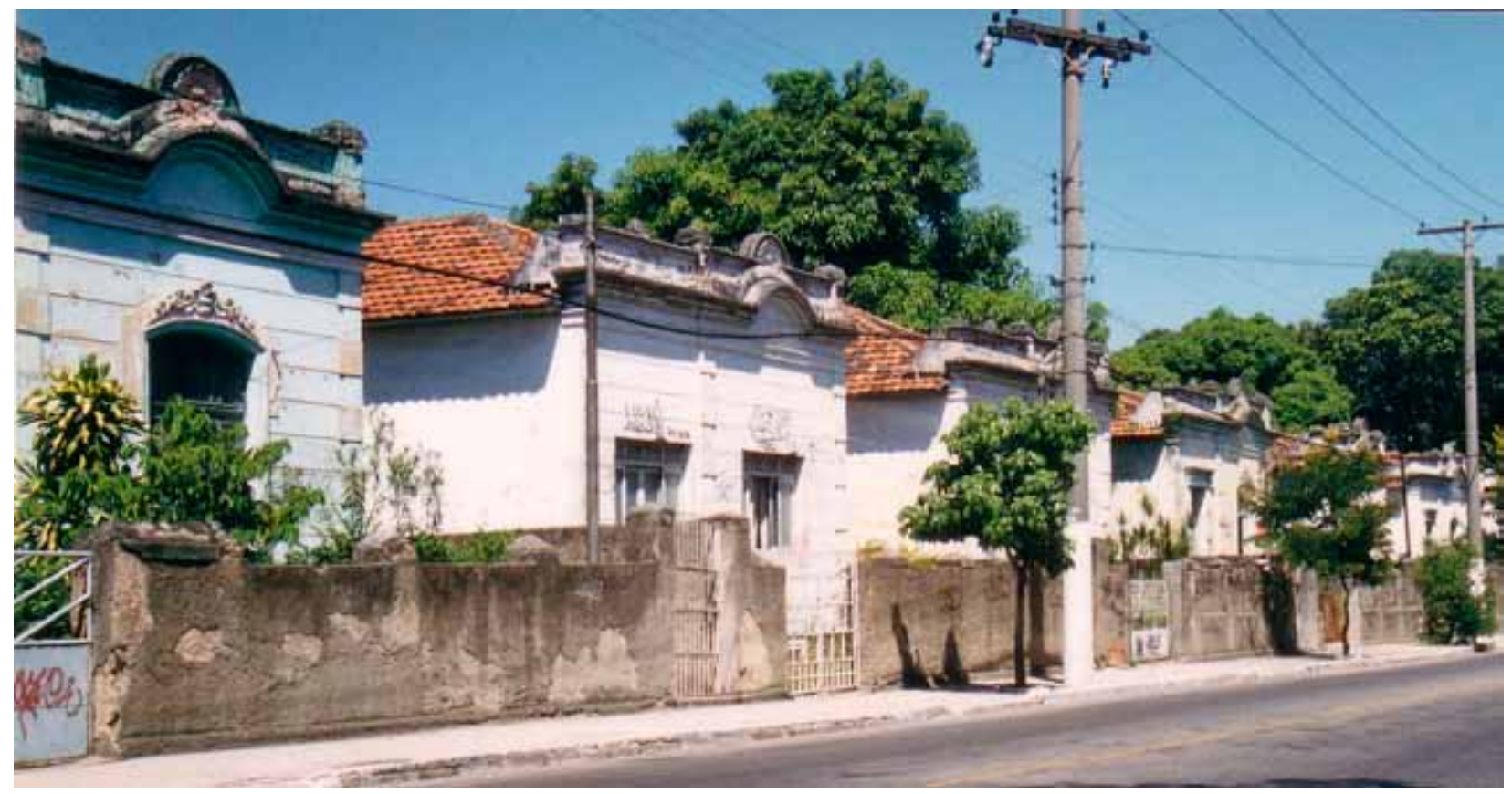

Figura 2 - Vilas operárias da Companhia Fluminense em Niterói (RJ). Fotografia de Philip Gunn, 1998.

Companhia Itabirito do Campo (Itabirito, MG); da América Fabril (Deodoro, RJ); da Fábrica Santa Cruz (Estância, SE); da Companhia Progresso (Salvador, BA). E também as casas de funcionário da Hidrelétrica Carioca, da Companhia de Tecidos Santanense (Pará de Minas, MG); a fachada do bloco de sobrados geminados erguido pela Fábrica Bonfim, da Companhia América Fabril, (praia do Caju, Rio de Janeiro, RJ) (Figura 3); e a vila operária da Fábrica Rosa (Pesqueira, PE).

Em casas destinadas a gerentes, a ornamentação pode tornar-se mais difusa, incorporando, inclusive, as iniciais da companhia em lugar de destaque na platibanda, que pode assumir formas mais movimentadas e adquirir uma certa monumentalidade. Exemplo disso são as moradias destinadas a chefes da Companhia Cachoeira de Macacos (MG) (Figuras 4a e 4b).

No cenário de vilas operárias e núcleos fabris erguidos no período em questão, o ecletismo encontrou expressão privilegiada na arquitetura de prédios de uso coletivo, como os das escolas, mas, sobretudo, os das igrejas e os das fábricas. Um exemplo disso é a escola da Vila Boa Viagem, em Salvador, com sua fachada amplamente ornamentada com pilastras, molduras, cornijas, frisos, apliques e compoteiras, tendo, como elemento central, um óculo com relógio enfatizando o papel essencial da escola na difusão de uma nova disciplina do tempo. A biblioteca da vila operária da Fábrica Santa Cruz, em Estância (SE) com sua platibanda decorada por escultura (águia), por conchas e por um delicado rendilhado vazado - também indica a prioridade conferida pela indústria aos prédios ligados à educação (Figura 5). 


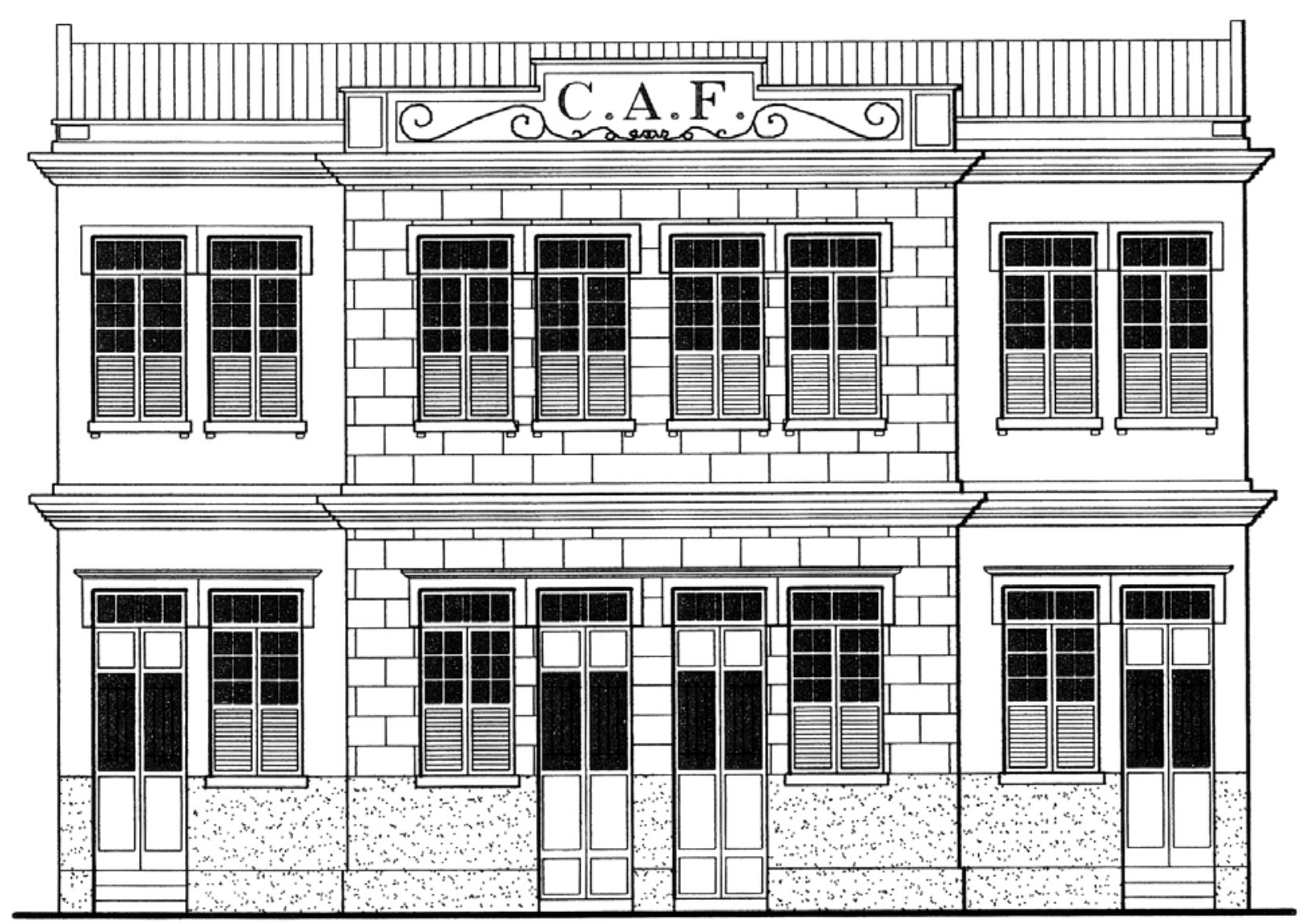

Figura 3 - Casas construídas no início do século XX pela Fábrica Bonfim, da Companhia América Fabril, na região portuária do Rio de Janeiro. Desenho (fachada) feito com base em projeto original publicado em Elizabeth von der Weid e Ana Maria Bastos (1986, p. 177). Fonte: acervo de Telma de Barros Correia.

Nesse mesmo período, as igrejas construídas por fábricas em suas vilas operárias e núcleos fabris adotaram como referência estilística, sobretudo, o românico e o gótico, estilos que costumavam ser julgados, na época, como apropriados para inspirar o projeto de igrejas católicas, na medida em que se difundiram quando do florescimento do cristianismo, ao contrário da arquitetura clássica com suas raízes "pagãs"7. Se comparado ao gótico, o românico era julgado particularmente apropriado para as igrejas despretensiosas e de pequenas dimensões, por sua maior simplicidade.

Um vocabulário românico - em versão muito simplificada - pode ser observado na capela da Charqueada São Domingos, no Rio Grande do Sul, onde o uso é claramente indicado pela fachada, apesar das dimensões modestas, da composição simples e da escassez de ornatos. Na maior parte das igrejas construídas por fábricas, as dimensões ampliam-se um pouco, enquanto são incorporados elementos típicos da arquitetura religiosa católica (torres, óculos e vitrais). $\bigcirc$ vocabulário românico se fez presente na igreja erguida em Caieiras - dotada de uma torre sineira lateral, portal e vitrais em arco pleno e contrafortes
7. Cf. Claude Mignot (1994, p. 48,101).Já na obra Contrasts, publicada em 1836, o gravador, designer e arquiteto inglês Pugin argumentava que o estilo clássico era pagão e que isso se refletia em sua orientação horizontal, enquanto o gótico seria o único estilo cristão, apontando para o céu, para Deus; apud Carl Schorske (2000, p. 996). 


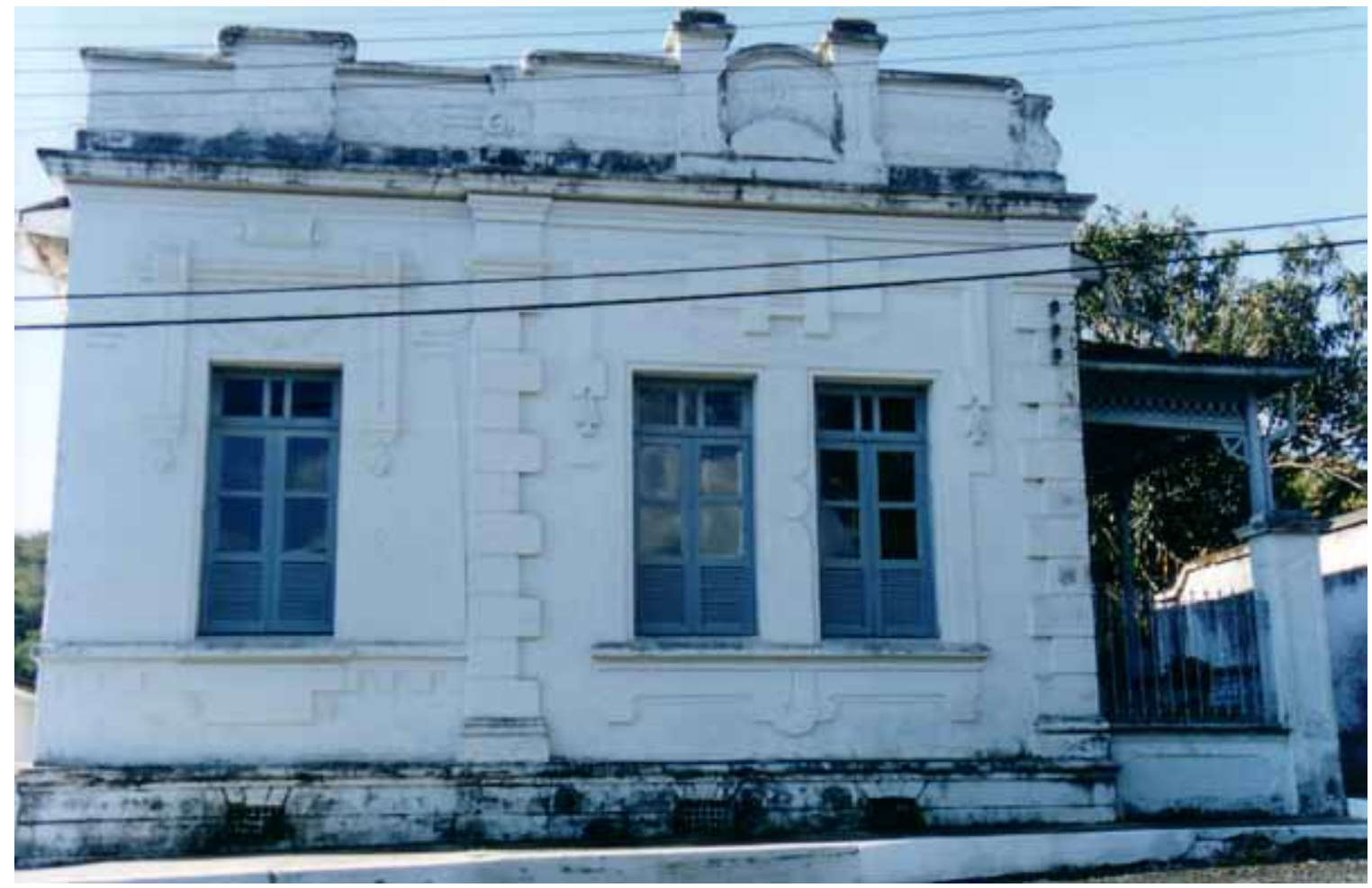

Figura 4a - Casa da Cia. Cachoeira de Macacos (MG). Fotografia de Philip Gunn, 1998.

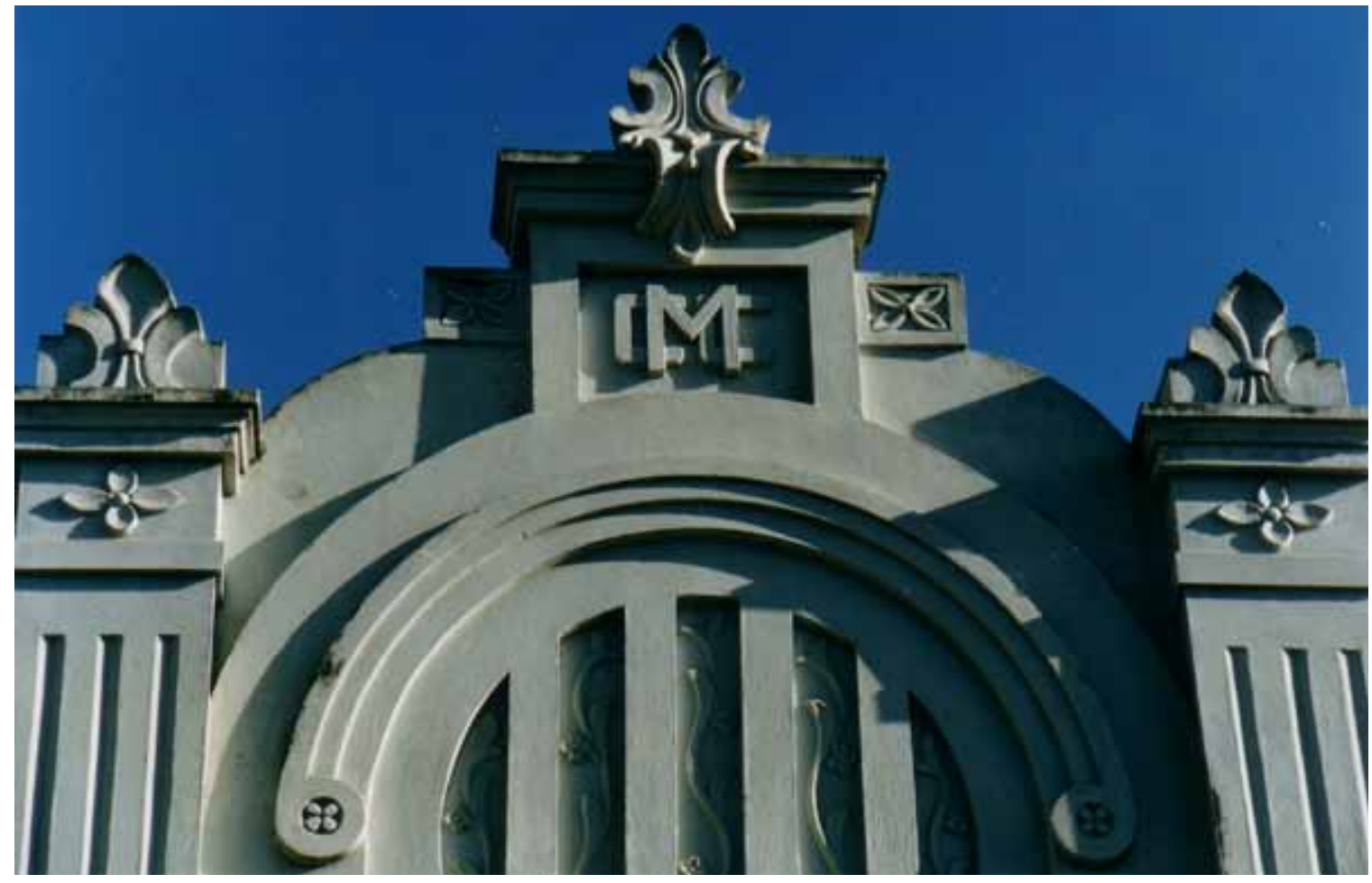

Figura 4b - Detalhe da fachada de uma casa da Cia. Cachoeira de Macacos (MG). Fotografia de Philip Gunn, 1998. 


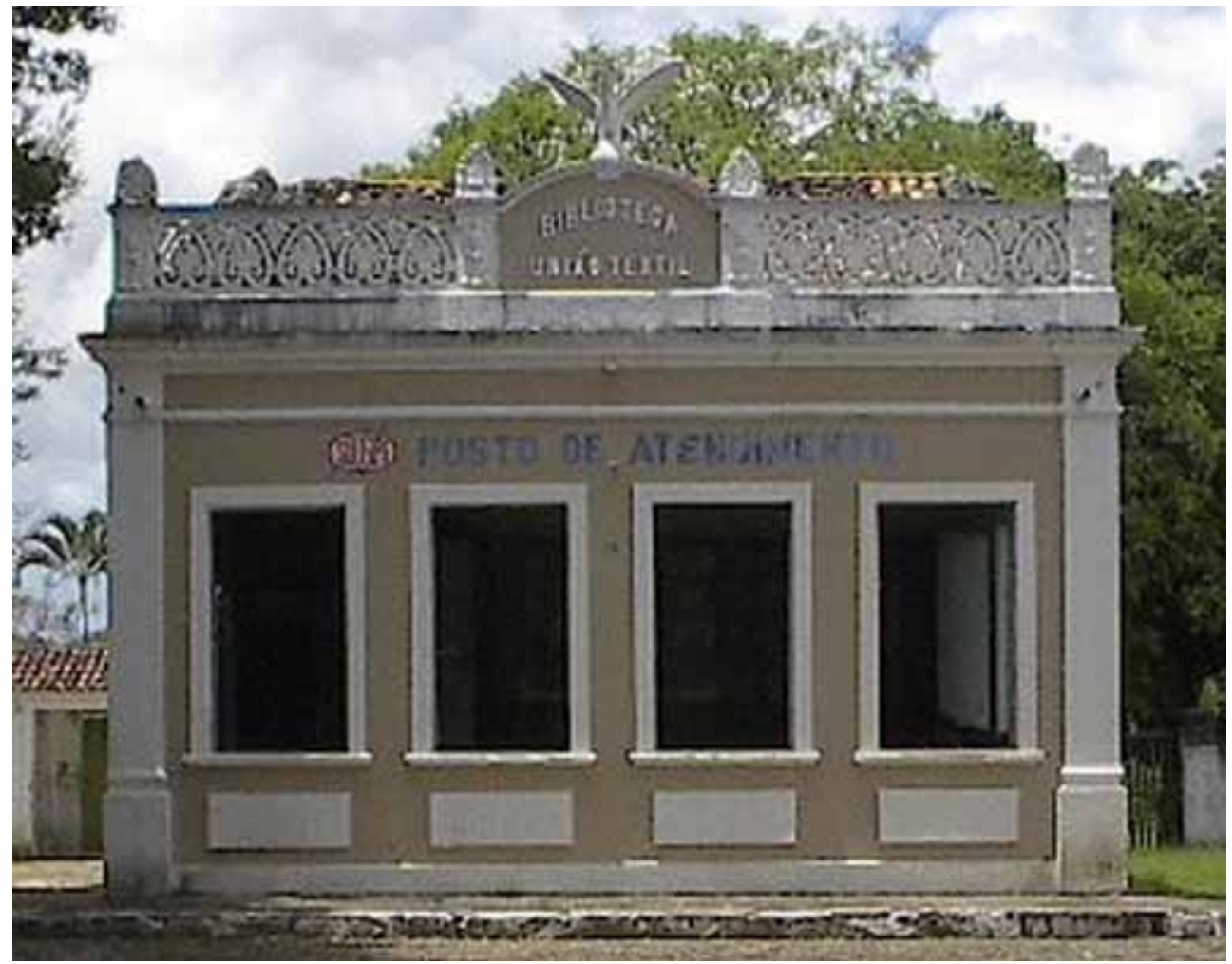

Figura 5 - Biblioteca da vila operária da Fábrica Santa Cruz, em Estância (SE). Fonte: BOMFIM, 2007, p. 183.

-, e na da Fábrica Santa Cruz, em Estância - onde também se observam portais e vitrais em arco pleno e contrafortes, além da presença, na torre, de friso com arcos de volta redonda. Com seus vãos e nichos em arco pleno, seu portal dotado de intradorso e seus vitrais geminados com arco cego, a igreja que a Fábrica Cometa ergueu em Meio da Serra, no município de Petrópolis (RJ), remete à linguagem românica (Figura 6).

$\bigcirc$ vocabulário do gótico também foi mobilizado em igrejas, em cujas fachadas principais simétricas predominou uma composição verticalizada, obtida através de: vitrais ogivais delgados; portal central dotado de frontão, intradorso e arco ogival; pilastras dotadas de pináculos em suas extremidades; e uma torre campanária central com coruchéu delgado ${ }^{8}$. Nelas, o local da usual janela em rosácea pode ser ocupado por um vitral ${ }^{9}$ ou um óculo, enquanto, eventualmente, - desenho de pilastras laterais pode sugerir contrafortes. Exemplos dessa composição são as igrejas da vila operária da Fábrica Progresso Industrial, no bairro de Bangu, Rio de Janeiro (RJ), e as erguidas nos núcleos fabris de

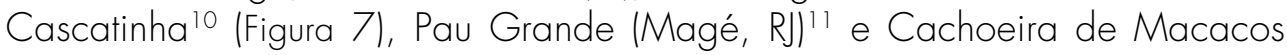
(Cachoeira do Prata, MG) ${ }^{12}$.

No núcleo fabril de Pedra, em Alagoas ${ }^{13}$, a igreja da década de 1920, cuja expressão externa é eclética, estabelece contrastes com a arquitetura
8. Dispor a torre no centro da fachada de igrejas góticas ocorre na Catedral de Ulm erguida no século XIV, naAlemanha; cf. Banister Fletcher (1987, p. 460-462).

9. Procedimento adotado em catedrais góticas, como a de Colônia, na Alemanha, construída a partir de 1284; cf. Banister Fletcher (1987, p. 466).

10. Núcleo erguido pela Companhia Petropolitana, nos arredores de Petrópolis (RJ), a partir de 1874 .

11. Criado pela Fábrica de Fiação e Tecidos Pau Grande a partir de 1878 .

12. Fundado pela Companhia Têxtil Cachoeira de Macacos, a partir de 1886, em Cachoeira do Prata (MG).

13. Núcleo construído por Delmiro Gouveia em Pedra, no sertão de Alagoas, a partir de 1912 . 


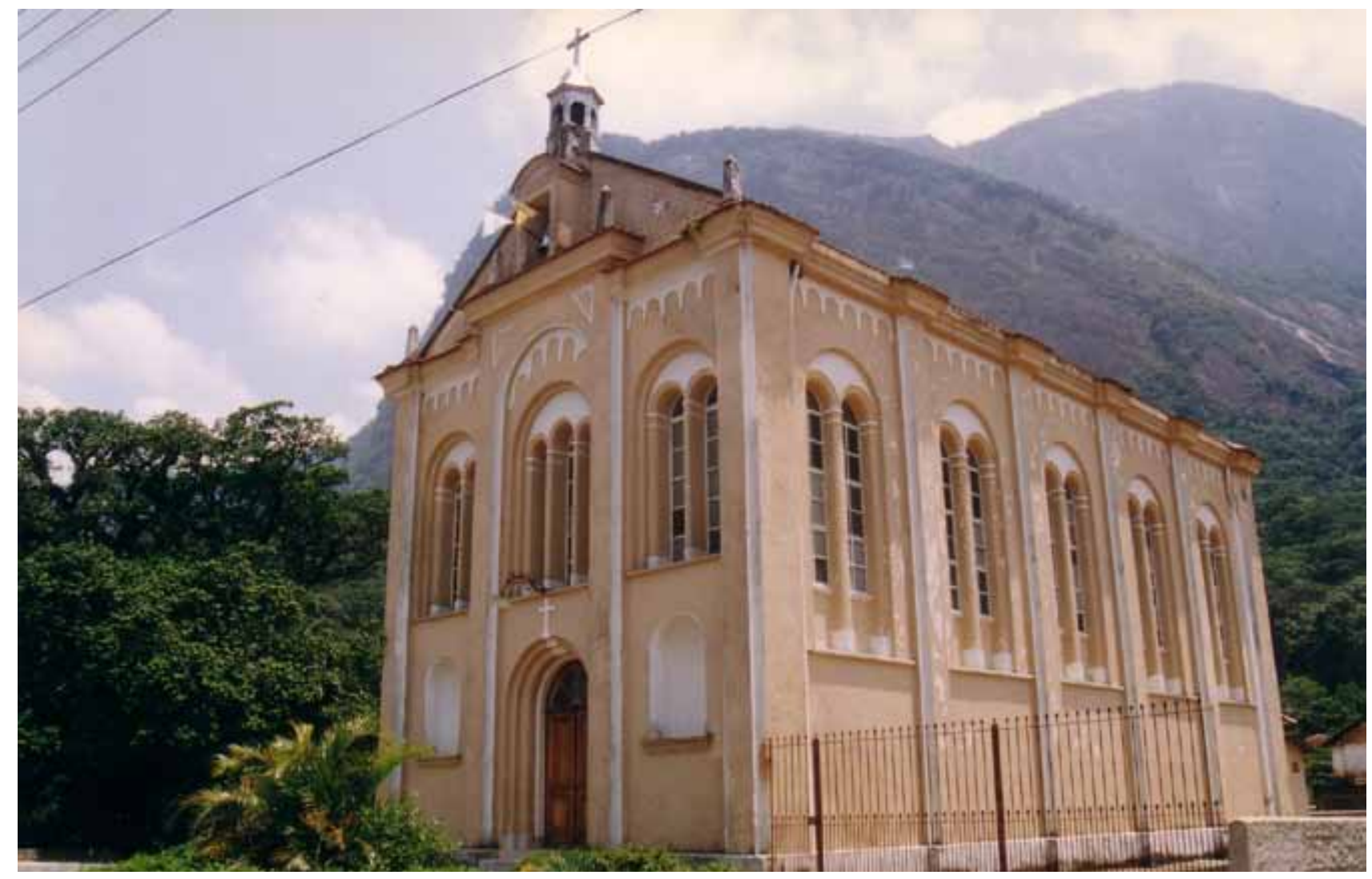

Figura 6 - Igreja da Fábrica Cometa, Meio da Serra, no município de Petrópolis (RJ). Fotografia de Philip Gunn, 1998.

14. Ver Banister Fletcher (1987).

15. Núcleo fabril erguido pela Companhia Industrial São Roberto, em Gouveia (MG), a partir de 1886 de forte filiação clássica das moradias dispostas em seu entorno, erguidas na década de 1910. Se as casas de Pedra causam admiração pela uniformidade da linguagem clássica que assinala o conjunto, sua igreja não deixa de surpreender pelo singelo e inusitado uso de elementos do gótico. Sua fachada remete a um portal triplo gótico, cuja ornamentação é promovida por desenho vazado, enfatizado por contorno em alto-relevo. Os três frontões, estilizados, remetem à forma do frontão ornamental gótico, embora desprovidos dos demais elementos que compõem a fachada de uma igreja gótica, entre eles as eventuais torres. Entretanto, em cada um dos frontões foram dispostos sinos que, face a esse uso e às suas formas verticalizadas, sugerem também torres sineiras (Figura 8).

Em várias igrejas erguidas, sobretudo na década de 1940, a composição se torna ainda mais despojada, com sua expressão externa fazendo referências bem mais distantes aos estilos do passado. Em algumas dessas igrejas, vãos, vitrais e pórticos em ogiva remetem - com grande imprecisão - ao vocabulário gótico. Em Bagé (RS), a igreja construída pela Cooperativa Industrial de Carnes e Derivados (depois Cicade Industrial de Carnes S.A.), na Vila Industrial (Figura 9), lembra formas do gótico inglês, tais como alguns exemplos de casas e castelos citados por Banister Fletcher ${ }^{14}$. A igreja de Gouveia ${ }^{15}$ lembra, de modo 


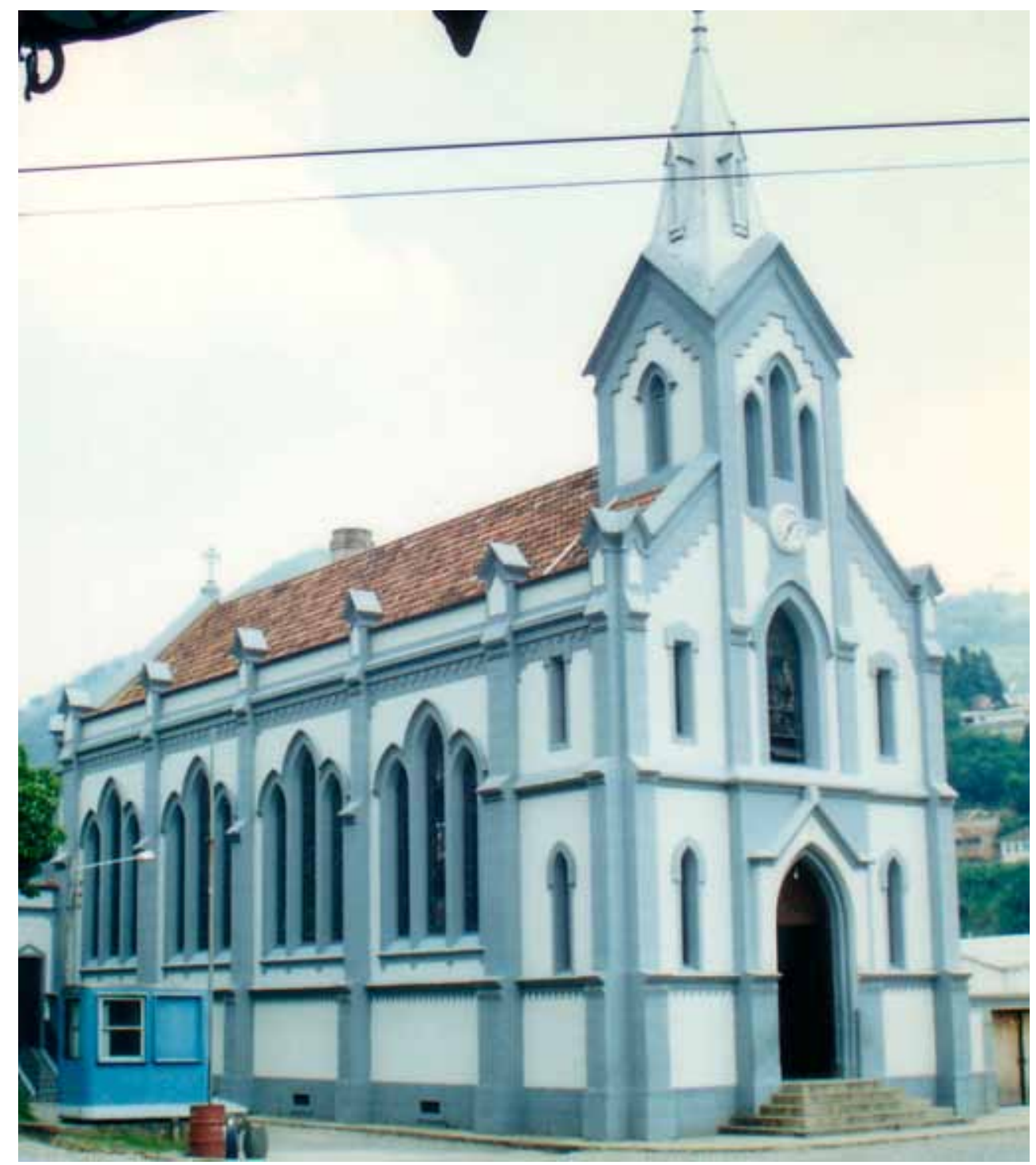

16. Construída pela Fábrica de Cimento Votorantim, Votoran, em Votorantim (SP).

Figura 7 - Igreja Cascatinha, no município de Petrópolis (RJ). Fotografia de Philip Gunn, 1998.

muito singelo, formas adotadas pelo movimento inglês Ecclesiological, do século XIX - como a igreja de Saint Mary, em Par, e a de Saint Wilfrid, em Hulme -, inspiradas na simplicidade de antigas casas rurais e em motivos do gótico.

Na capela erguida pela Fábrica Prada, em Limeira, notam-se referências ao românico, em uma fachada principal que chama a atenção pela desconcertante desproporção entre seus elementos componentes. Na igreja da Vila Santa Helena ${ }^{16}$, os vãos em arco pleno também lembram muito vagamente o românico, chamando atenção, neste caso (entre outras soluções de projeto), a quantidade inusitada de óculos (mais de vinte) distribuídos nas diversas fachadas. Essa quantidade despropositada de óculos iguais - assim como a repetição do 


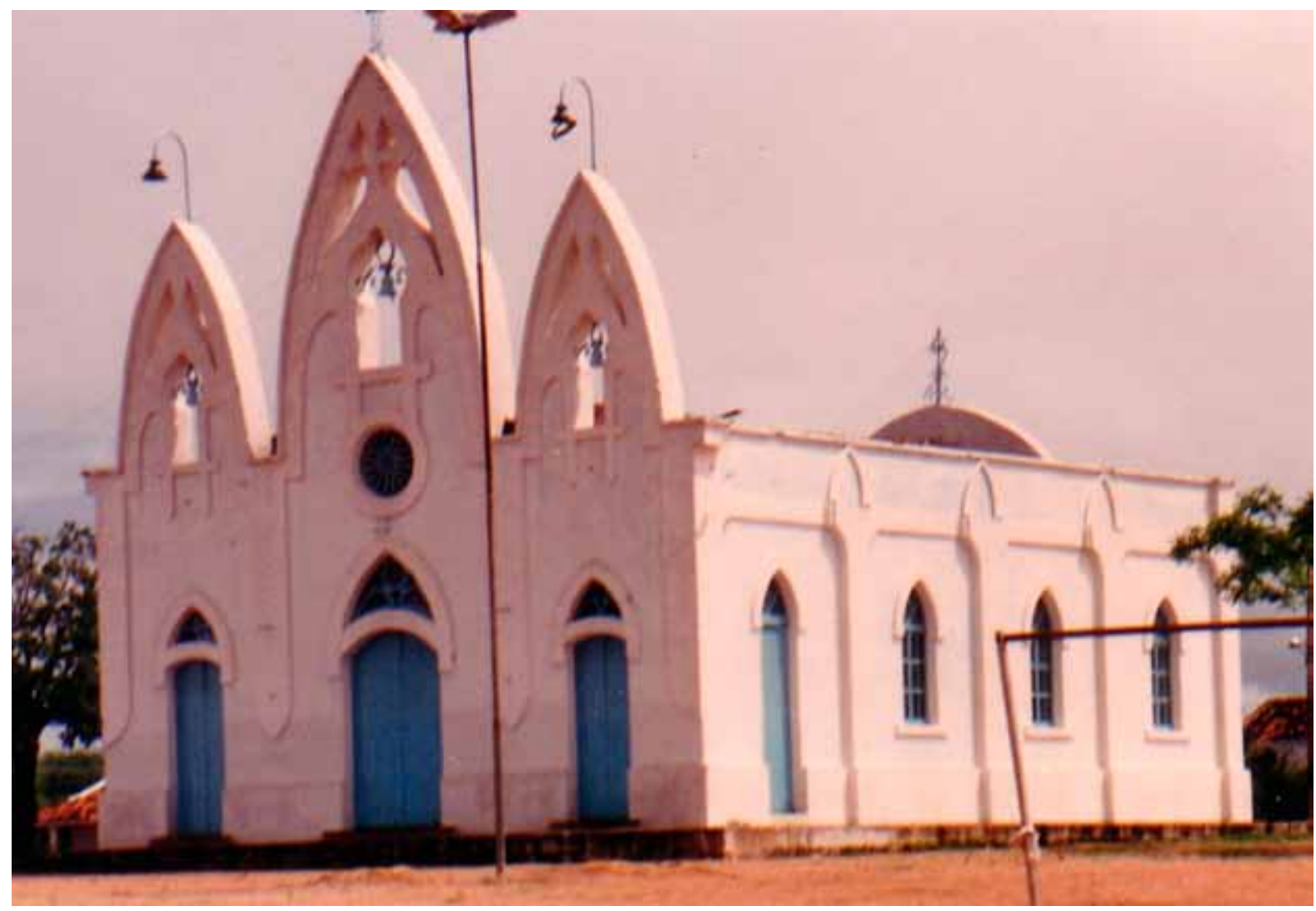

Figura 8 - Capela do Rosário, Pedra (AL). Fotografia de Philip Gunn, 1994.

desenho e da forma dos quinze vitrais - parece encontrar sentido na lógica de repetição seriada de elementos da produção industrial, além de evidenciar a falta de domínio, por parte do projetista, da linguagem, também manifestada em outros aspectos do projeto (Figura 10).

Em prédios de fábricas, o ecletismo encontrou diversas expressões. No prédio da São Joanense, em São João Del-Rei (MG), são recuperados elementos da linguagem clássica em uma composição onde os frontões triangulares surgem modificados pela introdução de um elemento de coroamento, além de compoteiras e desenhos em relevo (Figura 11 ). Em Juiz de Fora (MG), o prédio da Companhia Têxtil Bernardo Mascarenhas, construído em 1888, preserva algumas características da linguagem clássica - simetria, frontão, entablamento, óculo etc. -, numa composição fortemente carregada de elementos ornamentais de gosto eclético. Já na fachada principal do prédio da Fábrica Santa Cruz, em Estância (SE), os elementos decorativos se concentram, sobretudo, sobre a platibanda, enfatizando o acesso principal. Tal acesso é assinalado por porta larga, balaustrada, nome da fábrica em relevo, além de ornatos e volutas sobre a platibanda, enquanto o resto da fachada recebe uma ornamentação sóbria, 


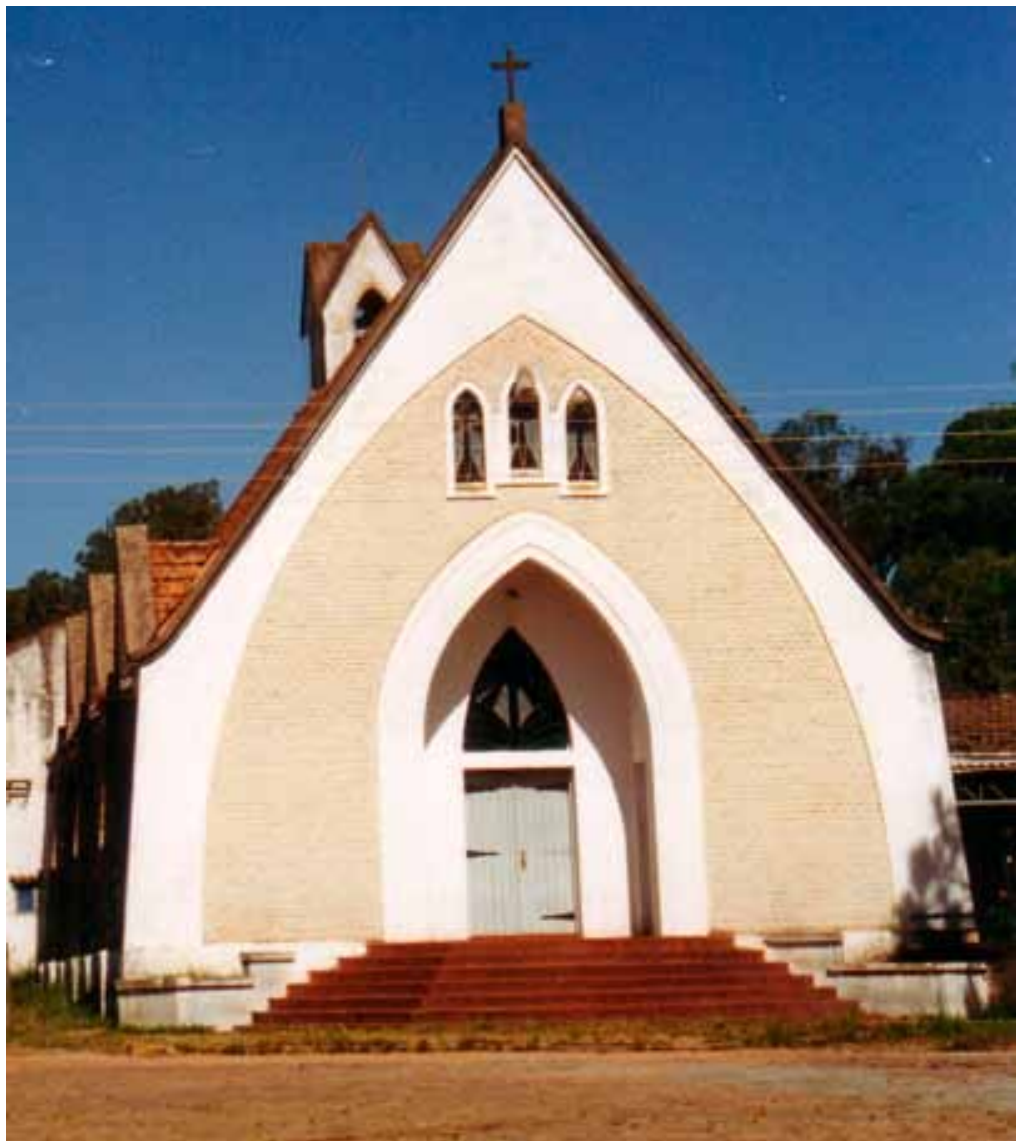

Figura 9 - -Igreja construída pela Cooperativa Industrial de Carnes e Derivados (Cicade), em Bagé (RS). Fotografia de Philip Gunn, 1997.

composta por pilastras, entablamento, cercaduras e desenhos geométricos em relevo (Figura 12).

Outras expressões de ecletismo em prédios fabris podem ser identificadas, numa versão muito despojada, no prédio da Fábrica da Pedra (AL), erguido na década de 1910; e no prédio da Companhia de Fiação e Tecidos Confiança Industrial, construído na década de 1880, em Vila Isabel, no Rio de Janeiro (RJ), onde se manifesta, sobretudo, na decoração rebuscada da torre central, que contrasta com a sobriedade das fachadas em alvenaria de pedra, ainda muito atreladas à forma da arquitetura do período colonial. Em versões mais claramente filiadas a modelos europeus, o gosto eclético revela-se nos prédios da Rheingantz, na cidade de Rio Grande (RS) (Figura 13) e da Fábrica Bangu (RJ). Nesses dois locais, telhados em escamas são utilizados nas partes de maior destaque da construção. Aí, nos prédios principais, em frontões no centro da fachada ou em torre, foram dispostos relógios, ocupando posições relevantes na composição. A presença desses relógios (substituindo óculos ou elementos decorativos), além do tratamento sóbrio das superfícies - em tijolo aparente ou com reboco ornamentado com linhas paralelas em baixo-relevo - também traduz a linguagem eclética segundo o utilitarismo inerente ao mundo industrial. 
Figura 10 - Igreja da Vila Santa Helena, construída pelo Grupo Votorantim, Votorantim (SP). Fotografia de Philip Gunn, 2002.
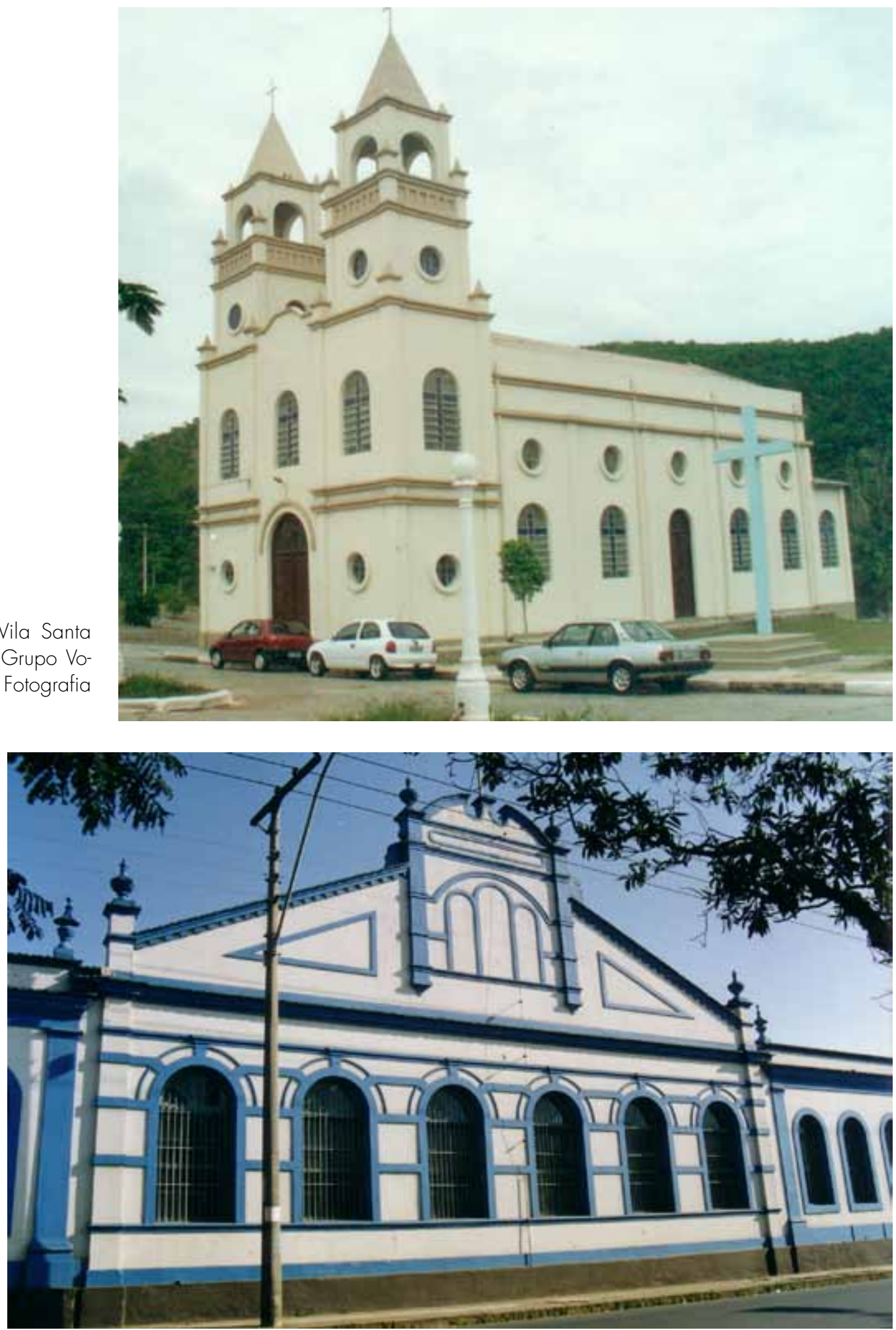

Figura 11 - Fábrica São Joanense, em São João Del-Rei (MG). Fotografia de Philip Gunn, 1998. 


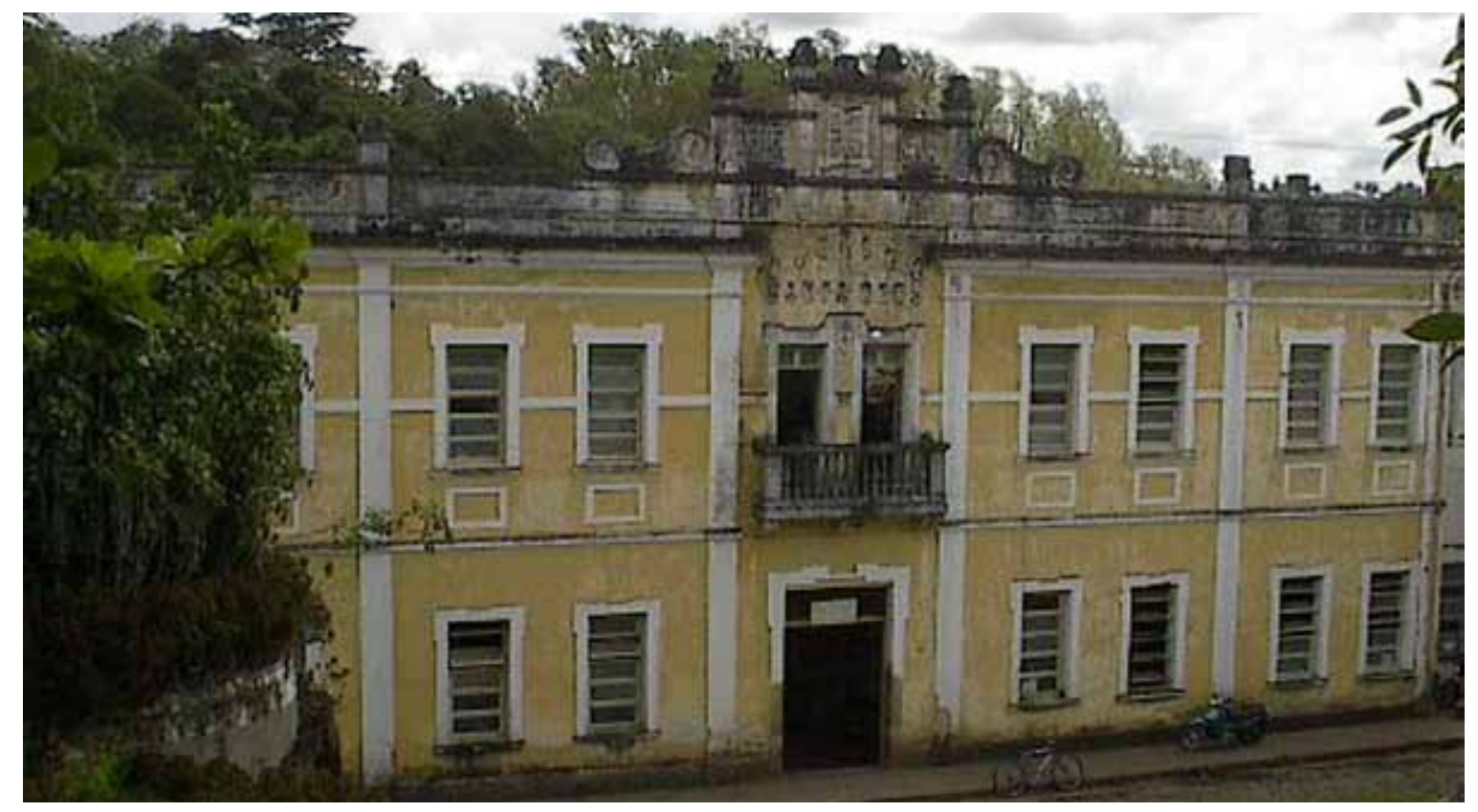

Figura 12 - Fábrica Santa Cruz, em Estância (SE). Fotografia de Suzete Bomfim, 2007.

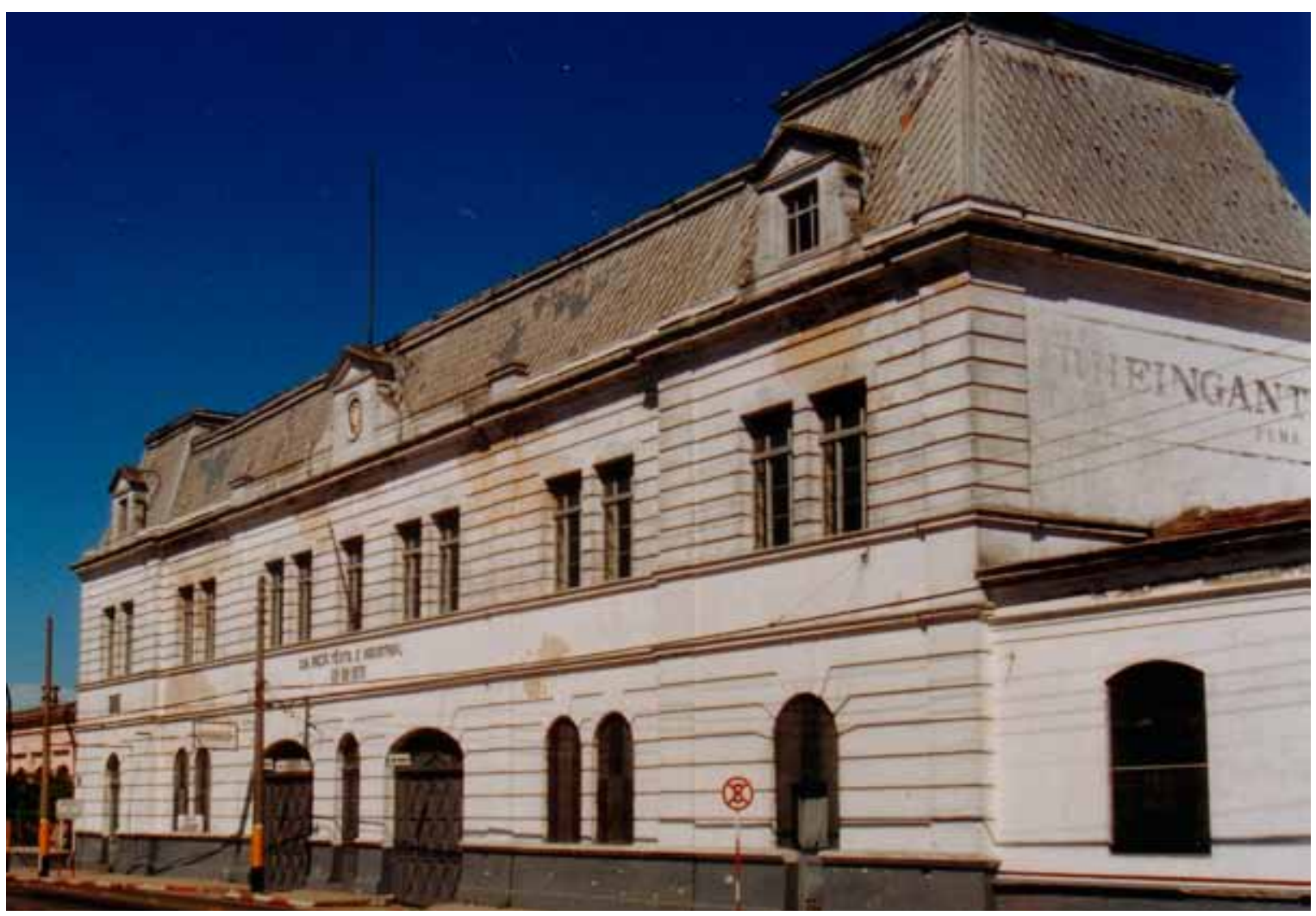

Figura 13 - Fábrica Rheingantz, em Rio Grande (RS). Fotografia de Philip Gunn, 1997. 
17. Cf. Gracilda A. de A. Silva (1989,p. 21-23)

18. Cf. Claude Mignot (1994, p. 100).
Na Fábrica Bangu, projetada e construída (entre 1889 e 1892) pela firma de engenharia De Morgan Snell, com sede em Londres ${ }^{17}$, a presença do tijolo aparente denuncia a difusão de uma linguagem nova que, a partir da década de 1880, vai caracterizar as áreas industriais no Brasil.

Nota-se, nos exemplos até aqui tratados, que o apelo a motivos ornamentais dá-se de forma seletiva e econômica, ao privilegiar as construções mais significativas do conjunto e restringir os ornatos, geralmente, a simples apliques, concentrados, muitas vezes, nas platibandas dos prédios. Assim, a lógica da profusão ornamental está presente, mas mediada pela noção de economia, central à organização fabril. Compoteiras, esculturas e composições baseadas em volutas surgem apenas eventualmente e, em geral, restritas aos prédios de uso coletivo e às fábricas, enquanto apliques à alvenaria se estendem a todos os prédios, embora dosados conforme o uso e a posição hierárquica de cada prédio no conjunto. Nessa hierarquia, as casas de gerentes costumam ser mais ornamentadas do que as de operários, enquanto, no âmbito de todo o conjunto, são privilegiados os prédios das igrejas e as fachadas principais das fábricas.

Como mostra Claude Mignot, ao referir-se ao historicismo na arquitetura europeia, não se trata de imitar com fidelidade a arquitetura do passado, mas de buscar nela elementos - um motivo, um princípio estrutural, uma forma arquetípica ou um layout - e adaptá-los às necessidades e recursos da época ${ }^{18}$. Se, nos exemplos já mencionados, tal adaptação é feita recorrendo a motivos e formas externos ao mundo fabril, inspirados na natureza ou na arquitetura do passado, em outros exemplos (como veremos a seguir), avança-se no sentido da busca de motivos no próprio mundo industrial - em suas máquinas, ferramentas e materiais produzidos em série.

\section{A emergência de uma estética fabril}

No Brasil, a partir de 1880, na arquitetura produzida por fábricas, é possivel identificar a constituição de um cenário que remete claramente ao mundo industrial, cujo aspecto essencial diz respeito às alterações ocorridas nos espaços de produção, que aumentam suas dimensões, adotam tipologias específicas e empregam nova linguagem e novos materiais de construção. Com seus amplos galpões e suas altas chaminés, tais construções desenham um novo cenário fabril, que reflete influências de modelos europeus e americanos, bem como mudanças na estrutura, no programa e no tamanho das unidades de produção.

Outro aspecto da difusão de uma estética tipicamente industrial manifesta-se nas construções anexas integrantes das vilas operárias e núcleos fabris: casas, escolas, igrejas, clubes etc. Tais lugares são importantes expressões da conversão do Brasil em uma sociedade industrial não apenas por suas origens, usos, funções e conflitos sociais, mas também pelas suas características formais, que usualmente remetem a valores, materiais e símbolos do mundo fabril. $\mathrm{Na}$ 
arquitetura de algumas dessas vilas e núcleos fabris, emergiu uma estética tipicamente industrial, fundamentada em noções de economia, eficiência, utilidade e funcionalidade. Tais noções se expressam ora em uma simplificação ou ausência de ornatos, ora no uso de ornatos cujos temas remetem ao mundo das máquinas, ou mesmo, às vezes, no distanciamento ou abandono de signos arquitetônicos tipológicos consagrados, enquanto, em outros exemplos, expressam-se no emprego de materiais - como o tijolo aparente e o ferro - produzidos industrialmente e que se difundiram, sobretudo, a partir da arquitetura de fábricas.

Materiais referentes ao mundo fabril

No Brasil, na época considerada, em conjuntos constituídos por fábricas e habitações para seus operários, uma das tendências da arquitetura foi adotar uma linguagem despojada, onde o tijolo aparente é ostentado em fachadas, e o ferro, em elementos estruturais e em componentes do sistema hidráulico (tubulações e calhas), muitas vezes também deixados à vista em fachadas e interiores. Nesses lugares, o tijolo aparente - usado em fábricas, moradias, igrejas etc. - torna-se um dos elementos característicos do conceito de funcionalidade que baliza esta nova paisagem industrial e sua forte expressão arquitetônica própria.

Nos países onde a indústria moderna avançou, o uso do tijolo aparente difundiu-se amplamente ao longo do século XIX, quando foi empregado, de início, em fábricas, pavilhões, galpões, estações de trem e em outros prédios associados às novas formas de produção, comércio e transporte. Das fábricas, o material foi rapidamente empregado em grupos de moradias operárias construídas em suas imediações. $\bigcirc$ uso do tijolo aparente em outras construções - inclusive moradias de alto padrão, igrejas etc. - difundiu-se na segunda metade do século XIX, a partir, sobretudo, da Inglaterra.

Tal difusão encontrou apoio na noção de "verdade na construção", defendida por Pugin e por outros arquitetos ingleses ligados ao revival gótico vitoriano, bem como por teóricos como John Ruskin e por integrantes do Movimento Arts and Crafts, como William Morris e Philip Webb. Em moradias burguesas, o material surgia vinculado a formas inspiradas em estilos do passado ou na arquitetura vernacular. Assim, no estilo Queen Anne, o tijolo vermelho era usado numa arquitetura que recorria a motivos clássicos. A Red House, projetada no final da década de 1850 por Philip Webb para William Morris, empregava tijolo aparente de forma refinada, em um vocabulário simples com alguns motivos medievais. $\bigcirc$ ideal de emprego de materiais e de elementos da tradição arquitetônica local nas construções, postulado pela maioria dos integrantes do Arts and Crafts, orientou construções erguidas com tijolo aparente. Na década de 1880, juntar-se-iam a essas noções as de unidade com a natureza e de simplicidade, criando as bases do revival da arquitetura doméstica inglesa do final do século XIX, com amplo emprego do tijolo aparente ${ }^{19}$.
19. Cf.Alastair Service (1977, p. 14-23). 
Em exemplos de cunho mais utilitário, como fábricas, o tijolo podia surgir em construções com estrutura metálica, que assinalavam o caráter do prédio e a tecnologia inovadora empregada em sua edificação. Em exemplos mais ornamentais - como prédios públicos e moradias burguesas - podia ser amplamente utilizado o brickwork, onde o material era fixado de modo a formar desenhos abstratos, em composições que usavam tijolos de diferentes cores ou dispostos de modo a criar formas em relevo. No caso de pavilhões, mercados e galerias, o ferro surgia muitas vezes associado ao vidro e, com menor frequência, também ao tijolo aparente, onde podia ser empregado o brickwork, sublinhando o requinte que se buscava conferir a tais instalações.

No cenário fabril brasileiro, o uso do tijolo aparente inicia-se nos galpões industriais, para depois ser, eventualmente, estendido a outras construções, como casas, igrejas, cinemas, escolas etc.

Em alguns conjuntos fabris, o tijolo aparente ficou restrito aos galpões da fábrica, como no prédio principal da Companhia Industrial Pernambucana, erguido por volta de 1890, em Camaragibe (PE), que articula o uso do tijolo aparente com motivos da arquitetura clássica, expressos em composição simétrica dotada de platibanda, pilastras, cornijas e galeria com arcadas. Tais motivos, entretanto, surgem simplificados e adaptados ao tijolo aparente, como evidencia o desenho simples das arquivoltas e dos pilares de seção quadrada da galeria monumental que percorre a fachada. Com suas arcadas (que lembram claustros de conventos religiosos do período colonial), o prédio sinaliza uma convergência do vocabulário clássico com o catolicismo militante do industrial Carlos Alberto de Menezes - engenheiro e provável autor do projeto da fábrica -, que mobilizou a religião católica como base e respaldo da ordem social que implantou nesse núcleo fabril, cuja igreja foi situada dentro da fábrica (Figura 14).

No prédio da Fábrica São Pedro de Alcântara, erguido em 1888, em Petrópolis (RJ), o tijolo aparente é empregado com parcimônia, através de frisos em brickwork, que decoram fachadas, onde as superfícies de alvenaria surgem revestidas com reboco, enquanto nos cunhais usam-se pedras (Figura 15).

No estado de São Paulo, utilizou-se, de modo amplo, o tijolo aparente em prédios fabris. Em suas fachadas extensas, surgem com frequência elementos da linguagem clássica - como frontões, pilastras, colunas, cimalhas etc. - embora modificados por alterações na forma e aplicações ornamentais próprias do gosto eclético (volutas, por exemplo, ou brickwork), que, em prédios dessa natureza, costumavam ser empregadas com parcimônia.

Exemplos, nesse sentido, são prédios de fábricas têxteis paulistas São Bento (fundada em Judiai em 1874), Nossa Senhora da Ponte (fundada em Sorocaba em 1881), Santa Rosália (fundada em Sorocaba em 1890); Santa Maria (fundada em Sorocaba em 1896), Mariângela (fundada em São Paulo pelas Indústrias Reunidas Francisco Matarazzo em 1907), Santa Adélia (fundada em Tatuí em 1908), e Fábrica de Tecidos Labor (construída na Mooca, em São Paulo) (Figuras 16 a 20). Algumas características da São Bento (Jundiaí, SP) como uso de tijolo aparente, iluminação zenital e tratamento padronizado da caixilharia - fazem Helena Saia supor que esta fábrica ou foi reformada nas 


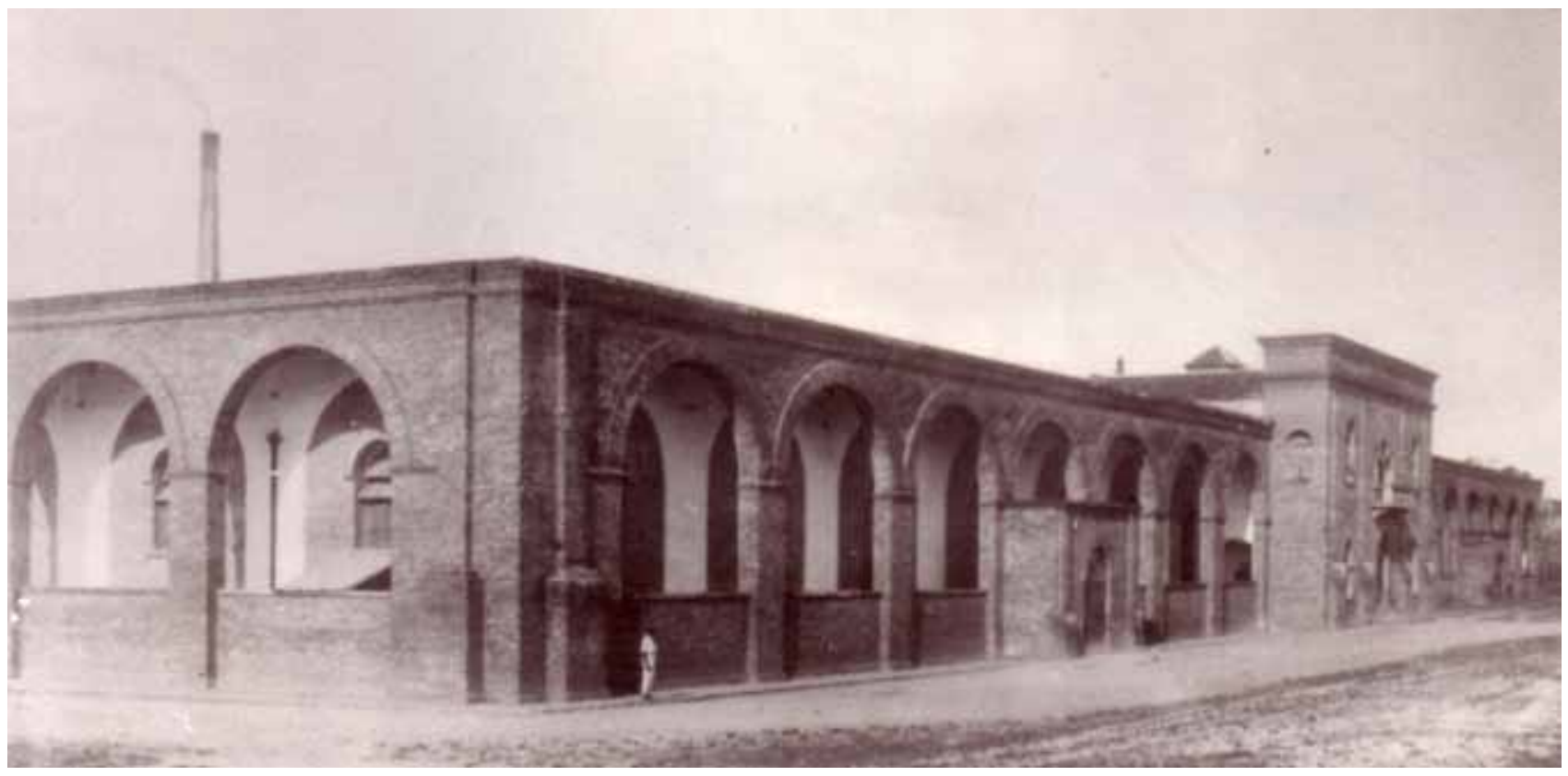

Figura 14 - Fábrica de Camaragibe (PE), criada em 1891. Fonte: FUNDAJ.

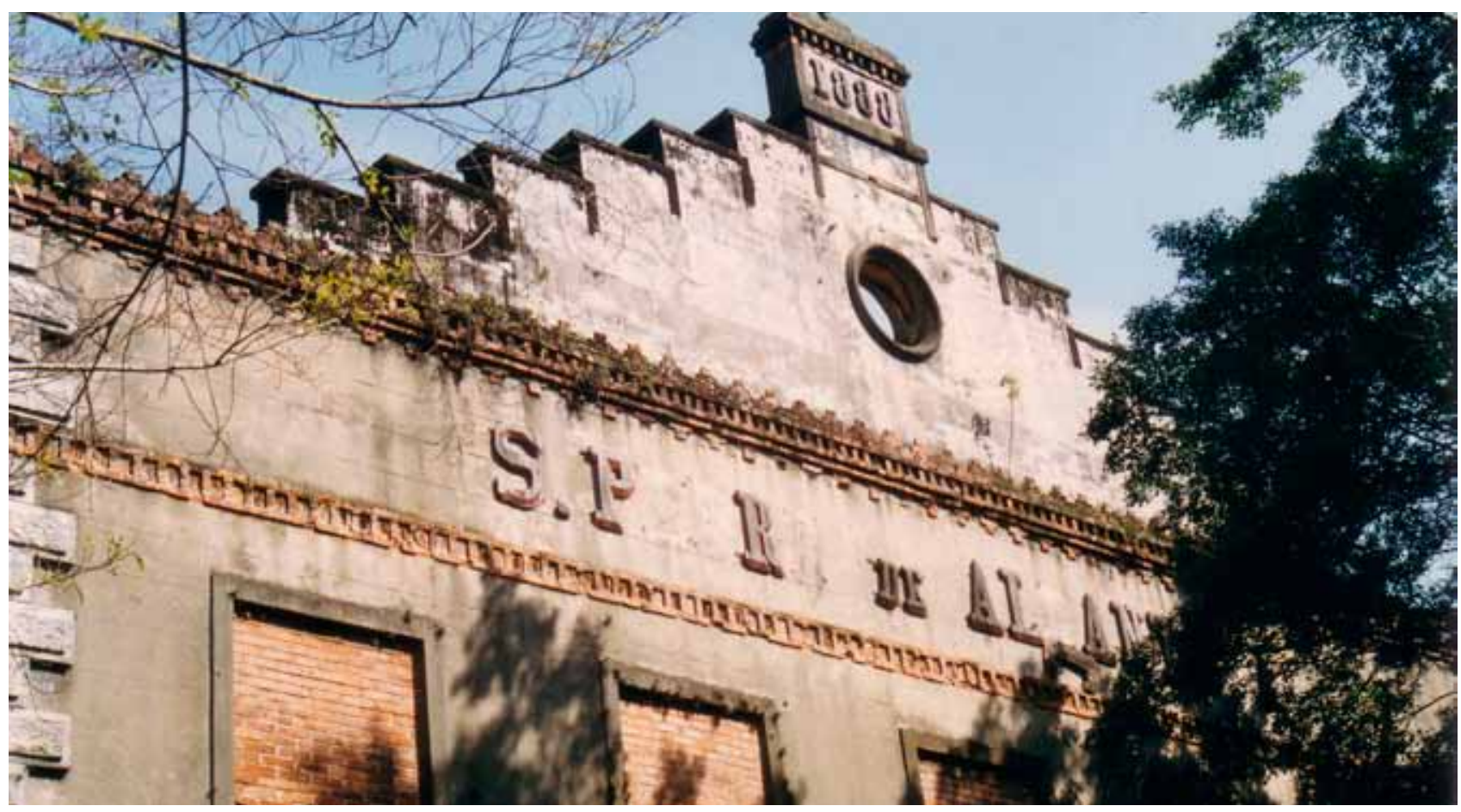

Figura 15 - Fábrica São Pedro de Alcântara, erguida em 1888 em Petrópolis (RJ). Fotografia de Philip Gunn, 1998. 


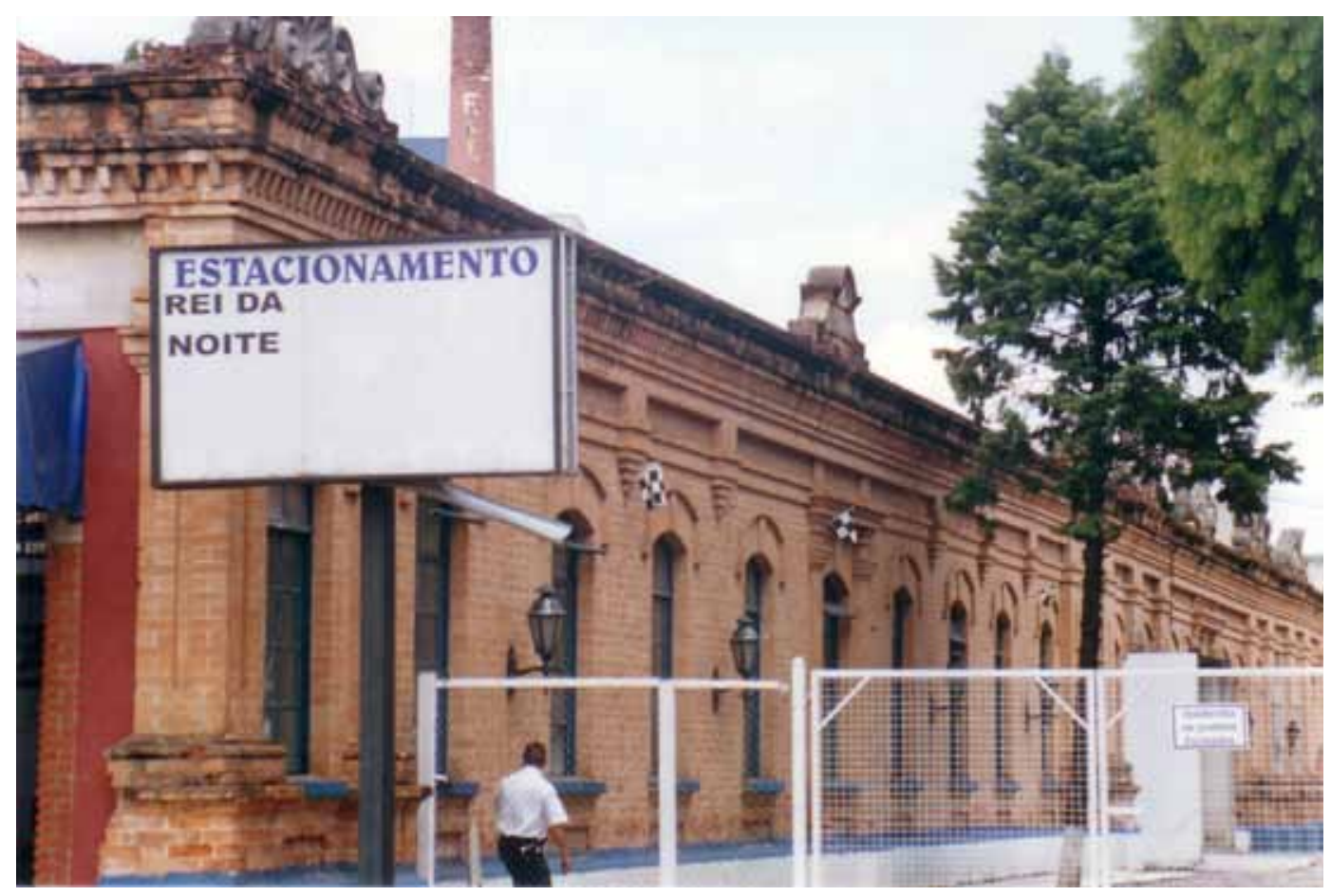

Figura 16 - Fábrica São Bento, fundada em 1874, em Jundiaí (SP). Fotografia de Philip Gunn, 2002.

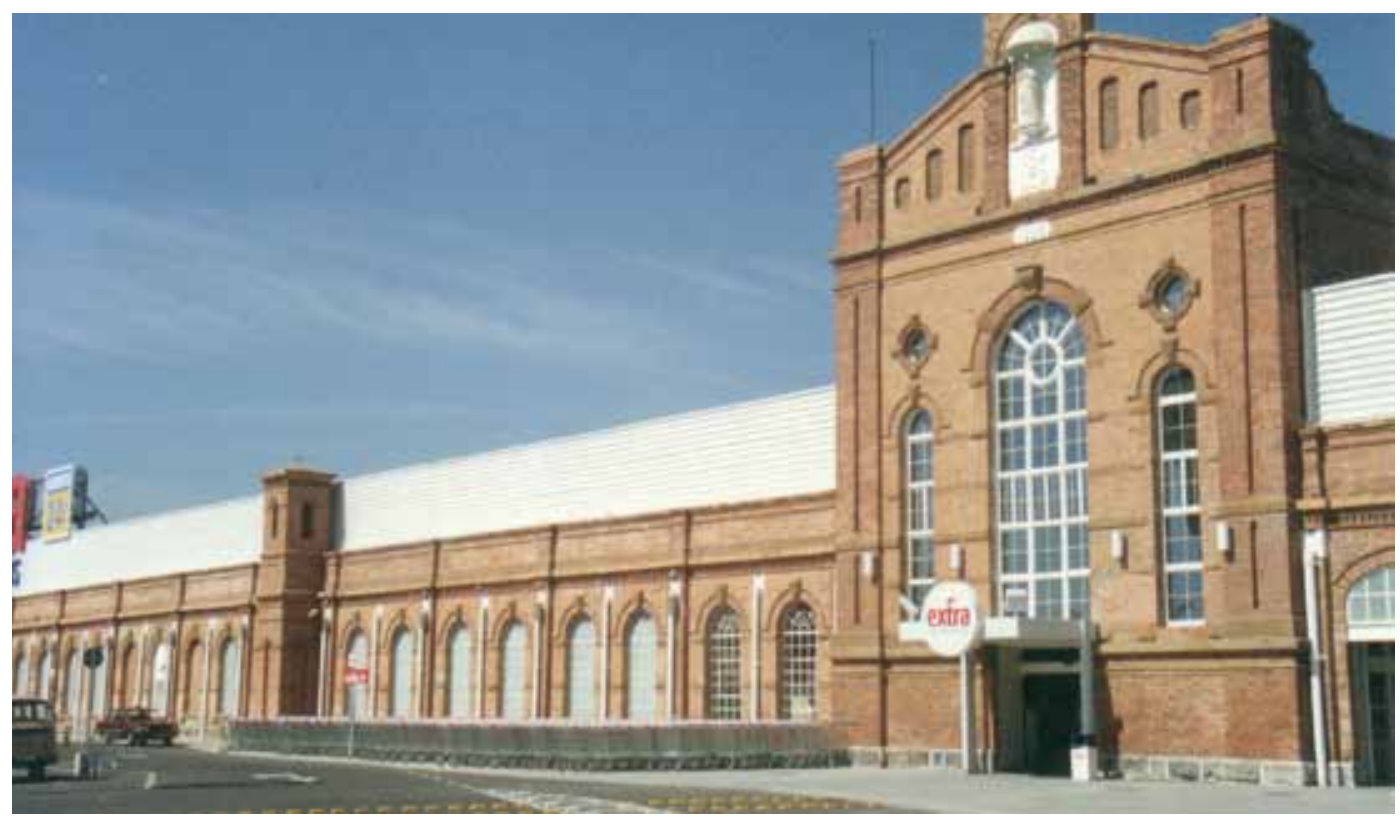

Figura 17 - Fábrica de Fiação e Tecidos Santa Rosália, construída em 1890, em Sorocaba (SP). Fotografia de Philip Gunn, 2001. 


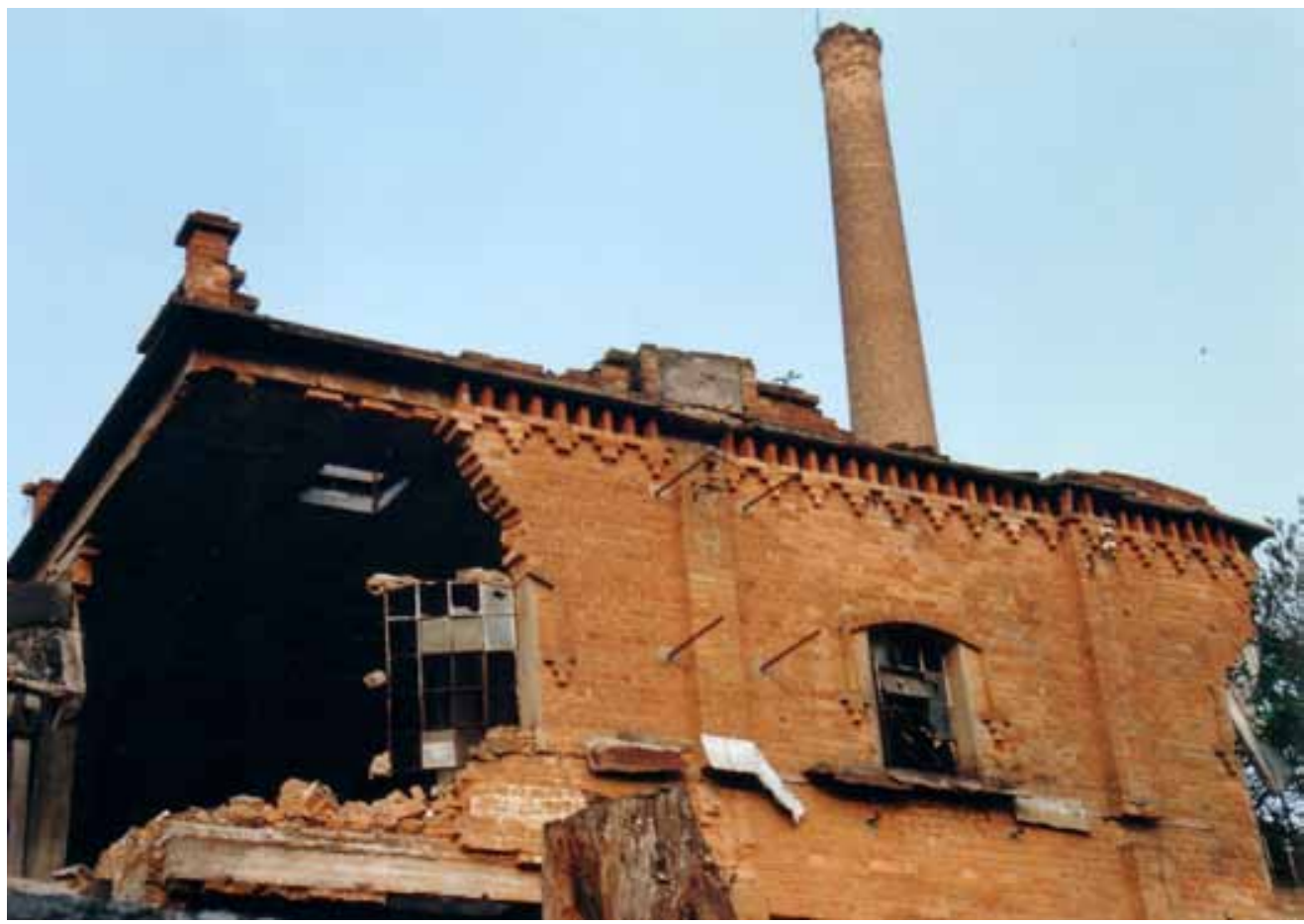

Figura 18 - Companhia de Fiação e Tecidos Santa Maria, fundada em 1896, em Sorocaba (SP). Fotografia de Philip Gunn, 2001.

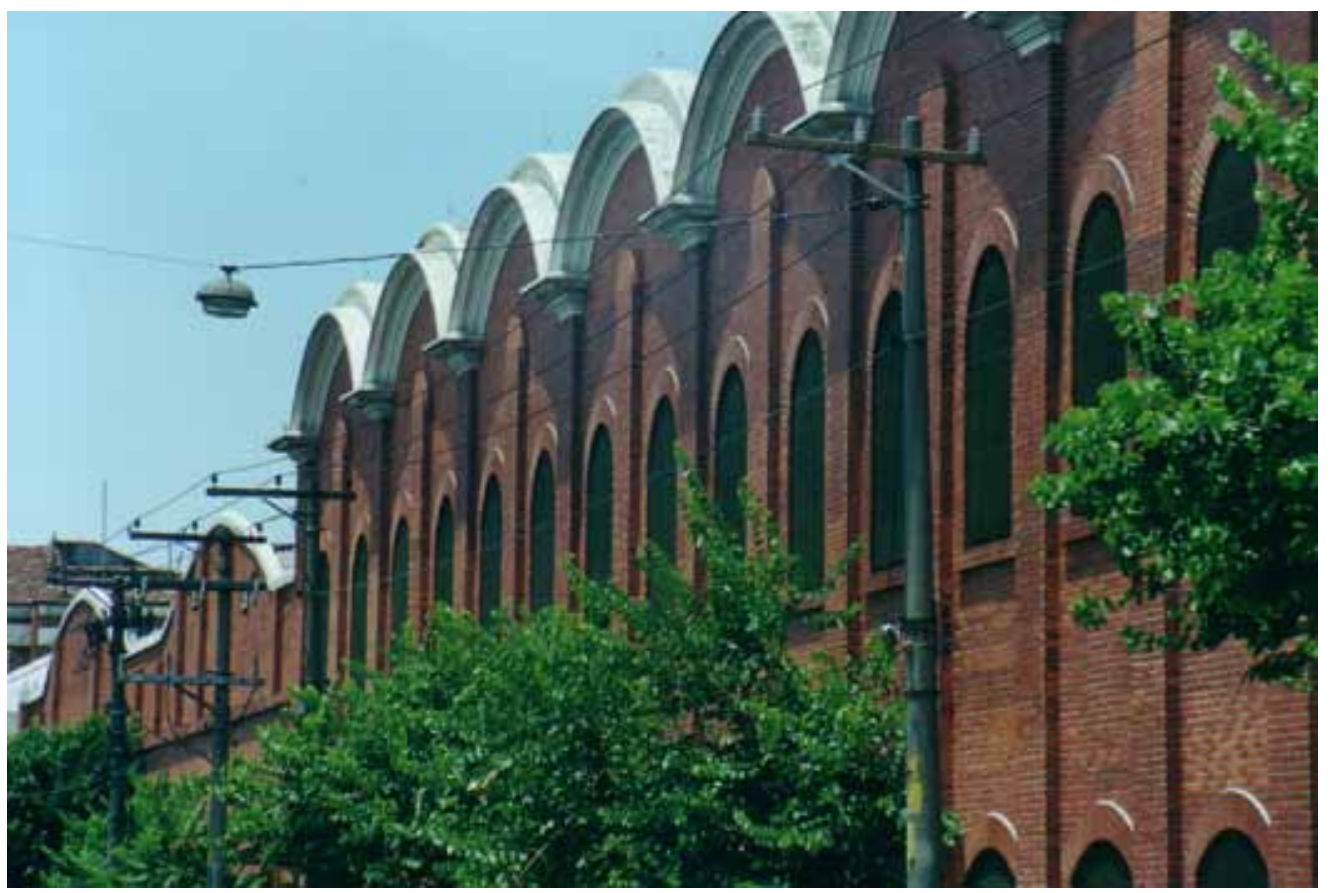

Figura 19 - Fábrica Mariângela, São Paulo, erguida pelas Indústrias Reunidas Francisco Matarazzo em 1907, em São Paulo (SP). Fotografia de Philip Gunn, 2001. 


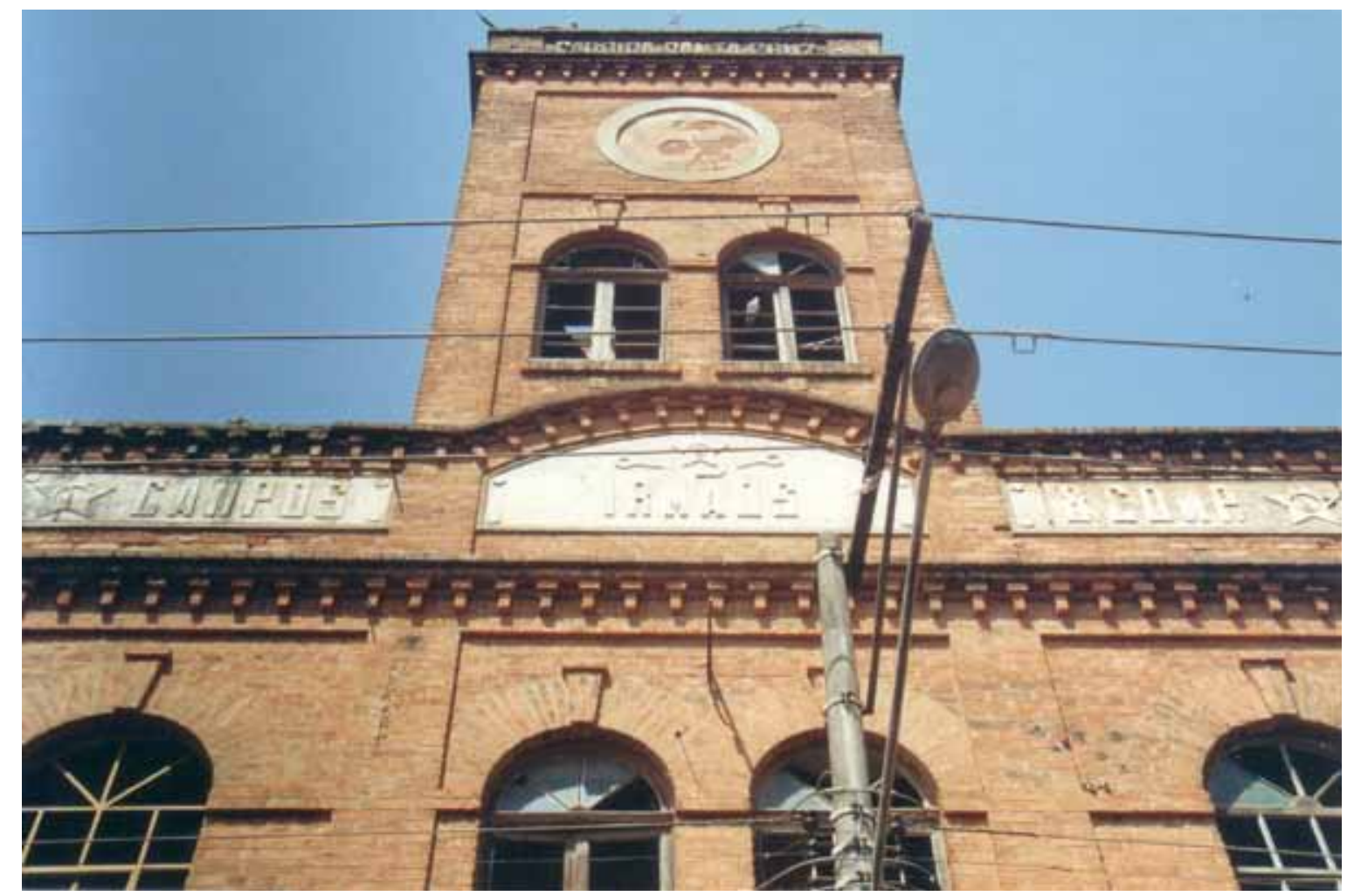

Figura 20 - Fábrica Santa Adélia, fundada em 1908, em Tatuí (SP). Fotografia de Philip Gunn, 2001.

20. Cf. Helena Saia (1989, p. 168).

21. Idem, p. 178. décadas finais do século XIX, ou trata-se da primeira a adotar soluções que só viriam a tornar-se usuais no estado de São Paulo no final daquele século ${ }^{20}$. A autora mostra que, entre as construídas nas décadas finais do século XIX no estado de São Paulo, as três fábricas de Sorocaba (já citadas) são as que mais se aproximam da tipologia gerada pelo modelo inglês de fábricas do século XIX, caracterizado pelas grandes fachadas em tijolo aparente, imensas chaminés e uso do ferro nas estruturas de pisos e cobertas. Ao contrário dos modelos ingleses, geralmente com vários andares, estas, entretanto, limitavam-se a um ou dois pavimentos $^{21}$. Já o prédio do Cotonifício Rodolfo Crespi, erguido no início do século XX no bairro da Mooca, em São Paulo (SP), é uma versão mais verticalizada e despojada do uso de tijolo aparente. O tijolo aparente também foi empregado na primeira fábrica de Francisco Matarazzo em São Paulo - o Moinho Matarazzo -, inaugurado no bairro do Brás em 1900 (Figura 21).

Em fábricas, em equipamentos de uso coletivo e em moradias destinadas a industriais e a funcionários graduados, nota-se a frequência com que surge o tijolo aparente, em composições ainda fortemente atreladas à linguagem clássica, dotadas de elementos como frontões, cornijas, pilastras, platibandas, frisos, cercaduras etc. Já nas fachadas de moradias destinadas a operários, a tendência é no sentido da simplificar ou eliminar os elementos decorativos. Nessas últimas moradias, os ornatos, como elementos essenciais da composição, tendem 


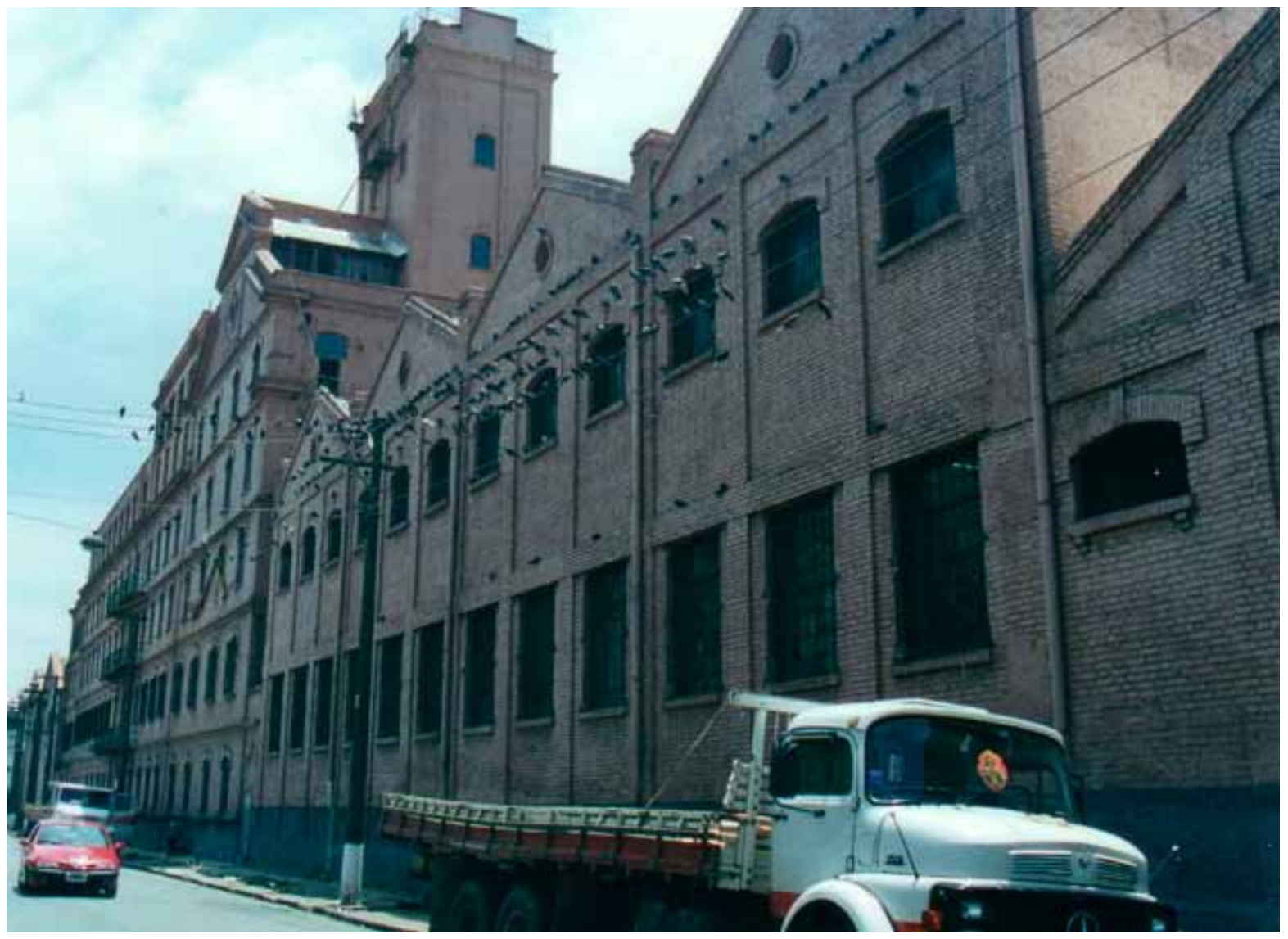

Figura 21 - Moinho Matarazzo, erguido em 1900, no bairro do Brás, São Paulo (SP). Fotografia de Philip Gunn, 2001.

a dar lugar a recursos como a variação de planos de fachada, o jogo de volumes e/ou o movimento do telhado. Tais recursos, além de conferirem qualidades formais à arquitetura sem encarecer muito a construção, compatibilizam-se com a lógica industrial de combate ao supérfluo no campo da produção ${ }^{22}$. Tal estratégia era recomendada, em 1906, pelo engenheiro Everardo Backheuser, ao sugerir a supressão dos elementos desnecessários da casa operária, inclusive os adornos, e substituí-los por uma variação de planos que, segundo defendia, iria movimentar as fachadas e conferir "um certo encanto" à habitação ${ }^{23}$.

Um exemplo de emprego amplo de tijolos aparentes são as casas erguidas pela Fábrica de Estamparia e Alvejaria Votorantim. Fundada em 1892, já em 1895 a fábrica estava instalada em amplos galpões de tijolo aparente. A eles se somariam outros prédios que, sucessivamente, foram sendo construídos, sobretudo, nas primeiras décadas do século XX. Entre o final do século XIX e a década de 1940, a fábrica criou e ampliou um núcleo fabril junto às suas instalações, em área rural no então distrito de Votorantim, do município de Sorocaba. Em 1914, a empresa contava com mais de 1200 operários e seu núcleo fabril criado incluía
22. Na lógica fabril, o combate ao supérfluo no campo da produção é concomitante ao empenho, no campo do consumo, em converter o supérfluo em necessidade.

23. Cf. Everardo Backheuser (1906, p. 47). 
24. Cf. Bráulio Werneck (1914,p. 48).

25. Cf. Carlos Lemos (1993, p.43). casas para operarios, em numero de 420, servidas por agua encanada e exgottos; 4 prédios nos quaes funccionam escolas publicas mixtas; um theatro, pequeno e elegante edificio, de gosto moderno; um coreto; casa de residencia do gerente; 3 grandes edificios tendo varias galerias e salas, nas quaes estão installadas as machinas e dynamos; escriptorio da administração, almoxarifado, depositos de tintas, sáes, drogas; dois grandes armazens particulares, destinados ao abastecimento da população operaria; agencia do correio; posto policial; matadouro, estação da via ferrea etc ${ }^{24}$.

Erguido pela fábrica, desde o final do século XIX até a década de 1920, o conjunto de construções tem, como elemento unificador, o uso do tijolo aparente. Recobrindo a quase totalidade das construções aí edificadas durante este período - exceto, entre outras, a igreja de São João -, o material integra e demarca os domínios da empresa. As instalações industriais ocupavam imensos galpões térreos, dotados de platibanda e amplas vidraças, decorados com ornatos em brickwork, junto aos quais se elevavam altas chaminés e uma torre. $\bigcirc$ engenheiro-arquiteto Ramos de Azevedo, entre 1890 e 1895, fez alguns projetos para a fábrica Votorantim, entre eles o de um forno de cal (1894) e prédios industriais, segundo Carlos Lemos ${ }^{25}$.

Nas casas em Votorantim, a presença de ornatos assinala a posição do morador na hierarquia fabril. A casa do industrial é um prédio de dois pavimentos, cercado de jardins, que, mantendo o tijolo aparente que na época recobria as construções do conjunto, tem forma e tratamento decorativo assinalando sutilmente sua primazia sobre as demais moradias. Na fachada, sóbria, elementos da linguagem clássica podem ser identificados em sua composição simétrica, com ênfase no acesso principal e em elementos como frontão, platibanda, entablamento e pilastras. Os motivos da linguagem clássica, entretanto, surgem mediados pelo tijolo aparente que recobre as superfícies e que, através de brickwork, desenha o frontão, define frisos, decora o entablamento e ornamenta as cercaduras. As casas destinadas aos chefes - térreas e cercadas por jardim - também são dotadas de pilastras e adornadas com frisos em brickwork, embora nelas a decoração apareça em menor profusão do que na moradia do industrial (Figura 22).

A disposição das casas dos operários assume diferentes configurações: às vezes, um renque de moradias térreas; outras, isoladas; podem também surgir geminadas, duas as duas, formando pequenos chalés; ov em blocos de sobrados. Algumas construções do século XIX são sobrados edificados com "tijolões" destituídos de reboco e de ornatos. Tais sobrados têm o mesmo partido dos que foram edificados em Marzagão e na Vila Boa Viagem - tratados a seguir - mas de forma ainda mais despojada, face à ausência de reboco e de pilastras nas fachadas. Em Votorantim, voltam a aparecer, iá no século XX, algumas tipologias em tijolo aparente, sem ornatos. (Figura 23).

No Rio de Janeiro, no núcleo fabril criado pela Companhia Progresso Industrial do Brasil, no bairro de Bangu, o tijolo aparente foi utilizado no prédio da fábrica (já citado), em casas geminadas e no prédio do teatro e cassino. $O$ último é um exemplo de equipamento coletivo erguido por indústria, conciliando o uso de tijolo aparente com motivos da linguagem clássica - pilastras, 


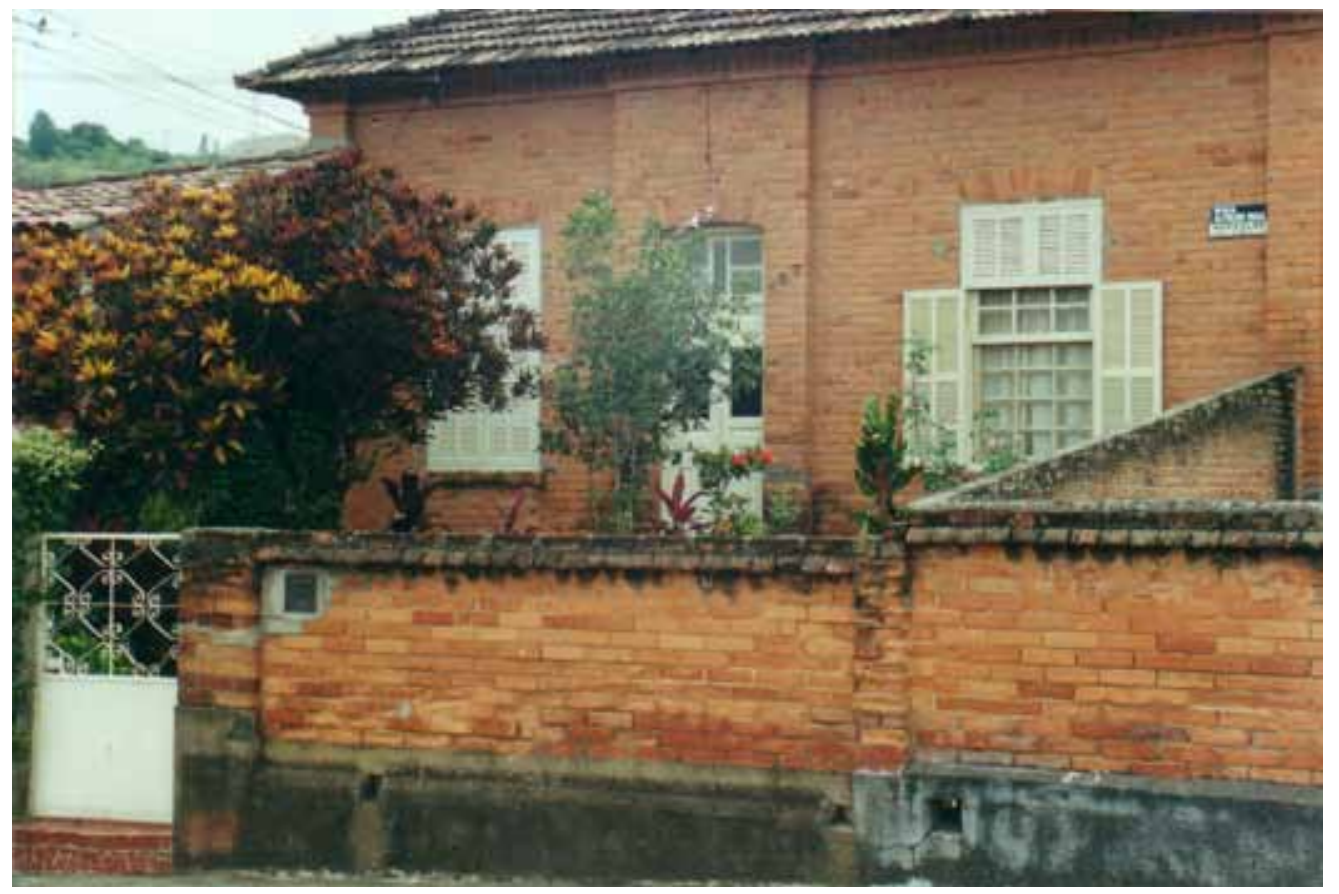

Figura 22 - Casas para técnicos especializados erguidas pela Fábrica de Estamparia e Alvejaria Votorantim, em Votorantim (SP). Fotografia de Philip Gunn, 2002.

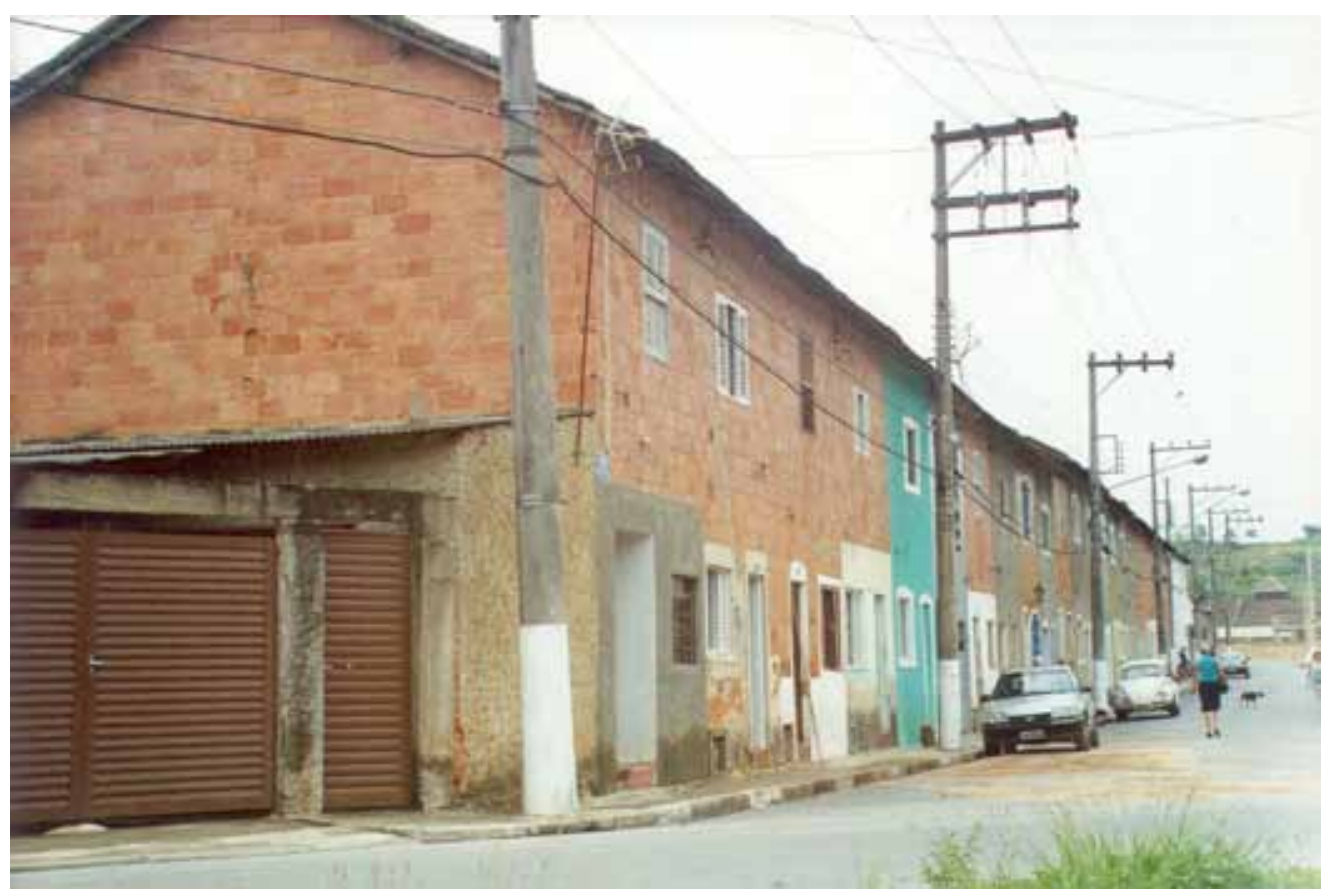

Figura 23 - Casas para operários erguidas pela Fábrica de Estamparia e Alvejaria Votorantim, em Votorantim (SP). Fotografia de Philip Gunn, 2002. 
entablamento, óculos etc. - utilizados com grande liberdade em relação às normas de composição próprias dessa arquitetura.

No início do século XX, o uso de tijolo aparente com escassos ornatos pode ser observado nos chalés geminados de duas vilas operárias. Nos da Companhia de Fiação Cometa, em Petrópolis (RJ), os ornatos surgem reduzidos a óculos e a uma estreita cercadura e guarnição de alvenaria sobre as janelas; nos da Companhia de Fiação e Tecidos Santa Maria, em Sorocaba (SP), a decoração da fachada é limitada a elemento em brickwork, sobre as janelas e delimitando a base do frontão (Figura 24). Na década de 1910, alguns chalés constituídos de sobrados geminados em tijolo aparente foram edificados em Galópolis núcleo fabril criado pelo Lanifício São Pedro, em um vale em área rural distante 11 quilômetros da cidade de Caxias do Sul (RS) - operando total abolição de ornatos (Figura 25).

Na maioria das construções - fábrica, vilas operárias e equipamentos coletivos - erguidas pela Brasital S.A. (antes Societá per L'Exportazione e per L'Industria Italo-Americana), em Salto de ltu (SP), foi utilizado tijolo aparente. Com exceção dos chalés da praça da Matriz, utilizam esse material as casas de todas as suas vilas operárias - Vila da Barra do Jundiaí, Vila Brasital, Vila da Barra do Tietê e Vila Porto Góes - construídas na cidade entre 1912 e 1946.

Nas instalações fabris, o material recobre e confere unidade a um conjunto de prédios dotados de motivos da linguagem clássica - frontão, cornija,

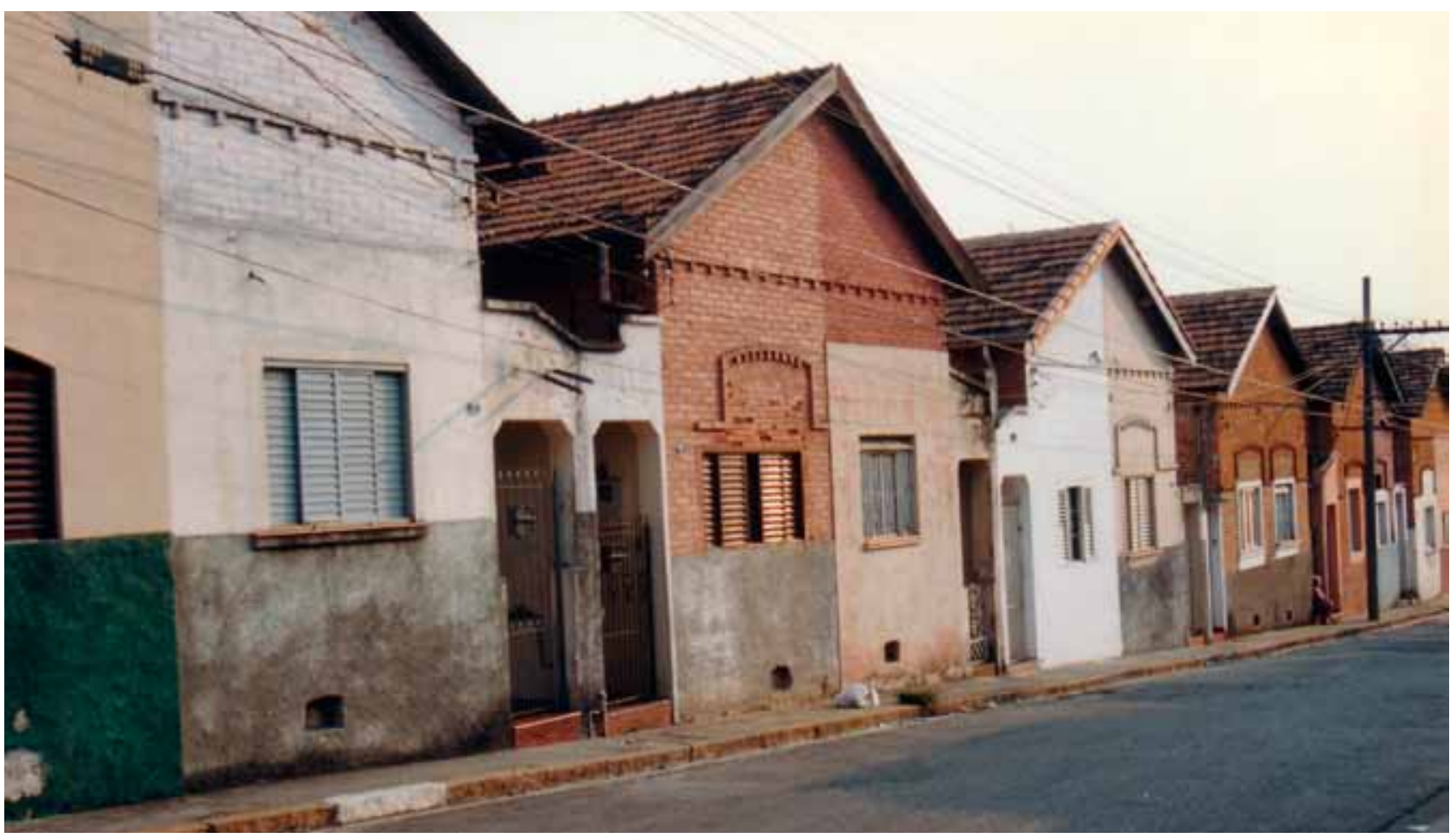

Figura 24 - Casas da vila da Companhia de Fiação e Tecidos Santa Maria, em Sorocaba (SP). Fotografia de Philip Gunn, 2002. 


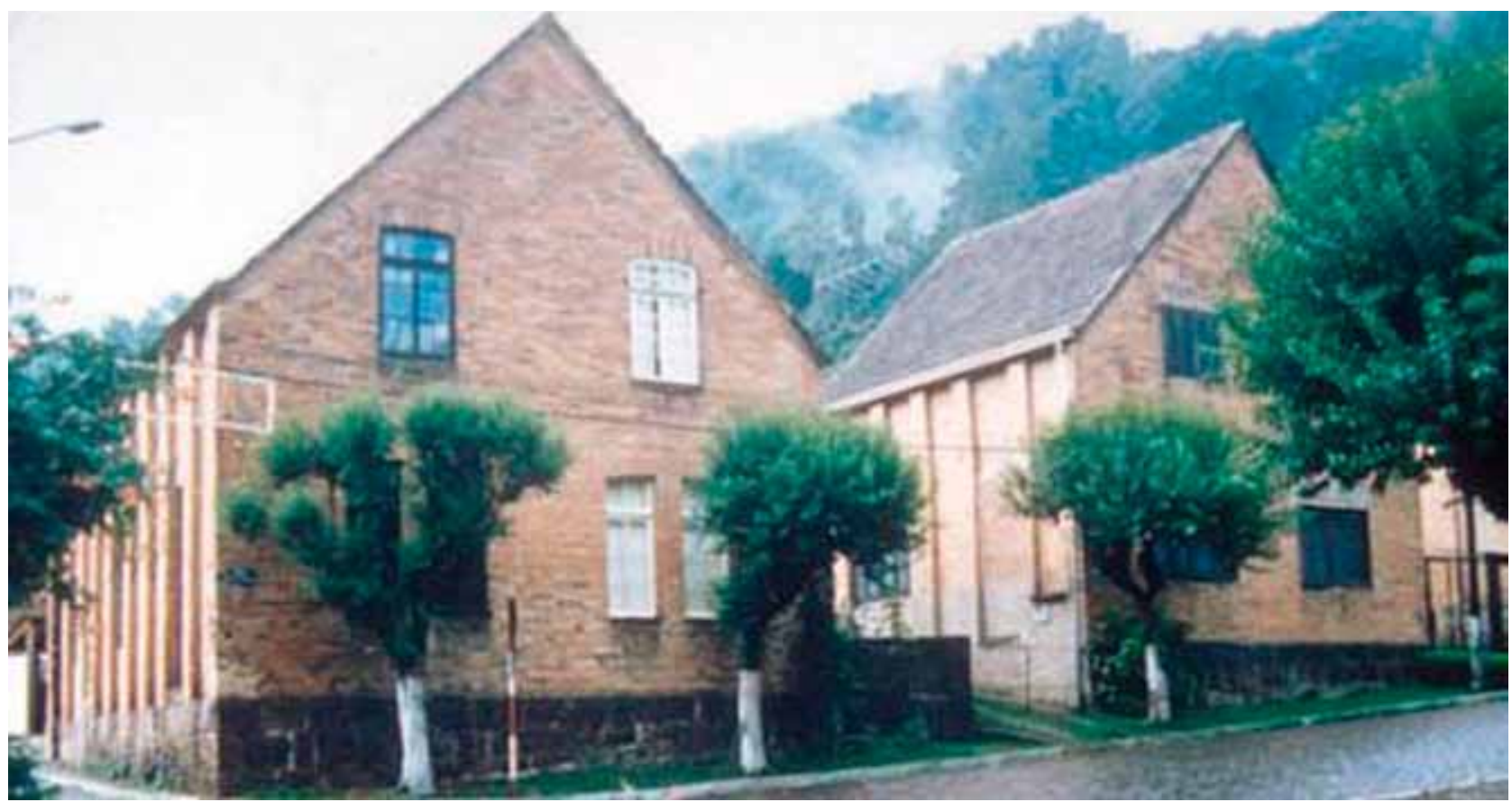

Figura 25 - Sobrados erguidos pelo Lanifício São Pedro, em Galópolis (RS). Fotografia de Philip Gunn, 1998.

óculo e pilastra -, um deles articulando esses motivos a outros, que remetem a fortalezas - torres e ameias (Figura 26). Anicleide Zequini considera possível que 26. Cf.Anicleide Zequini (2004, p.61). o prédio original da fábrica, inaugurado em 1875, tenha sido projetado pelos engenheiros da firma inglesa Platt Brothers \& Co, que vendeu as máquinas para a indústria ${ }^{26}$.

As trinta casas da Vila da Barra do Jundiaí, construídas em 1912, ocupam uma quadra em cujo centro há um quintal coletivo, acessível por uma viela estreita. Além de pequeno quintal, elas têm sala, quarto, cozinha e sanitário. Destinavam-se a contramestres e operários qualificados. Estão implantadas segundo a tradição colonial brasileira: dispostas em blocos de seis, sem recuo, com uma porta e uma janela na frente. Em algumas dessas casas a fachada de tijolo aparente de cada habitação é demarcada por pilastras, frisos e cimalhas rebocados (Figura 27). Elevando-se além da platibanda, as pilastras repetem o mesmo tratamento utilizado no prédio da fábrica Fortuna. Em outras dessas casas, a composição da fachada é simplificada eliminando a platibanda e elementos em reboco, com o tijolo aparente compondo pilastras, friso e cimalha.

Na Vila Brasital - construída entre 1920 e 1924 -, as moradias e a implantação revelam semelhanças com a Vila da Barra do Jundiaí: os "quintalões" e as casas dispostas em blocos, com fachadas de tijolo aparente e dotadas de janelas em todos os cômodos. Os blocos contavam com número de moradias variando entre 4 a 28. Ocupavam quatro quadras. Nessas casas, tem continuidade o movimento de simplificação das fachadas, sendo a pilastra e a 
Figura 26 - Fábrica da Brasital, em Salto (SP). Fotografia de Philip Gunn, 2001.

Figura 27 - Vila da Barra do Jundiaí, erguida pela Brasital em 1912, em Salto (SP). Fotografia de Philip Gunn, 2001.
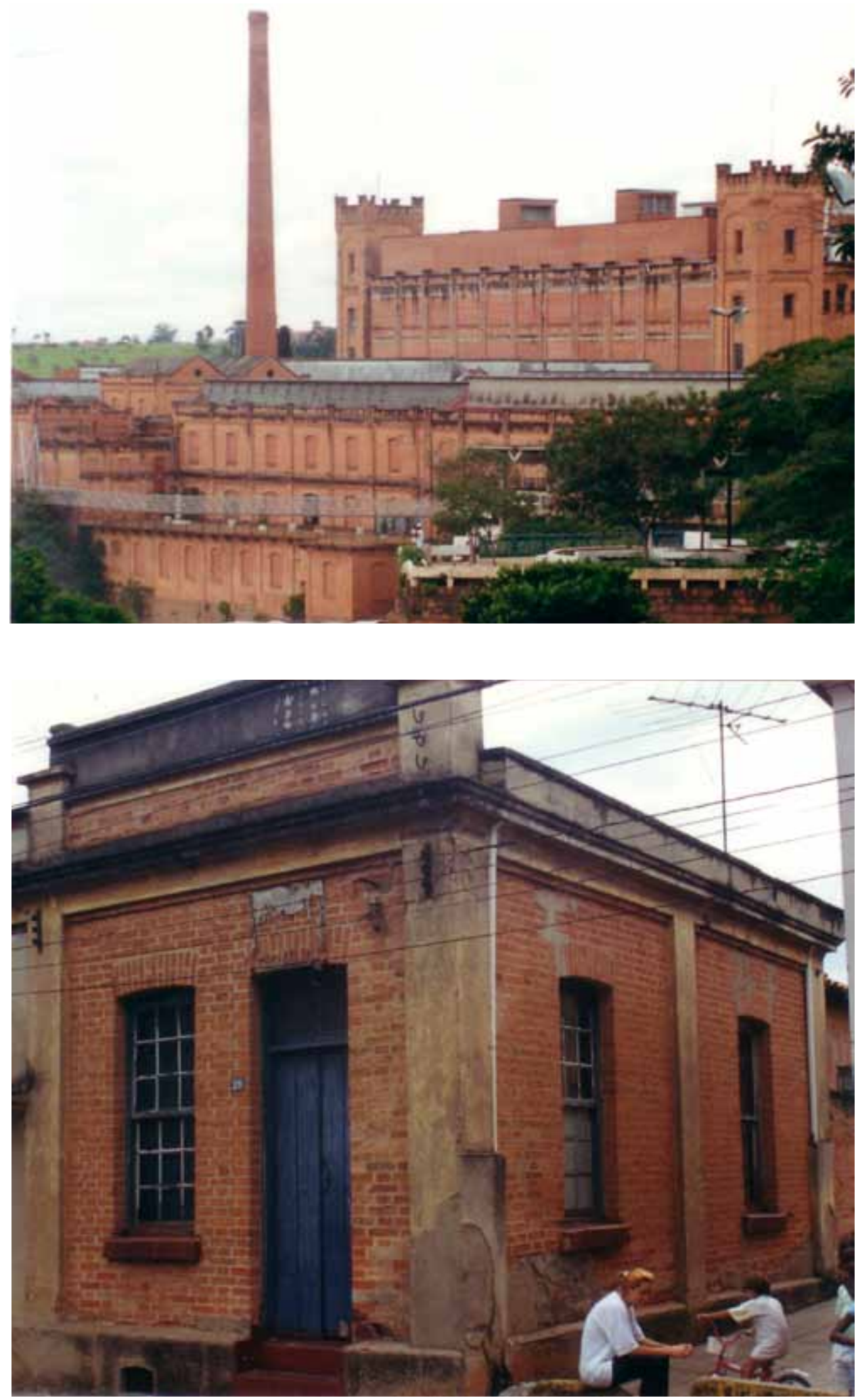

Anais do Museu Paulista.v. 19. n.1. jan.-jun. 2011. 
cimalha reduzidas a um elemento em alto-relevo, em reboco, contornando a fachada de tijolo aparente (Figura 28).

As dez casas construídas na Vila da Barra do Tietê na década de 1940, destinadas a gerentes, foram dispostas geminadas duas a duas. Com coberta em várias águas, volumetria composta, e um terraço com abertura em arco, elas adotam a tipologia que, no Brasil da época, ficou conhecida como bangalô (Figura 29).

O prédio da creche, que funcionou a partir de 1948, também utiliza tiiolo aparente na fachada. Nele, evidenciam-se elementos de composição clássica na fachada simétrica, com ênfase no acesso principal. $\bigcirc$ brickwork desenhando frisos, compondo painéis e emoldurando as amplas janelas de ferro e vidro com cercaduras - ornamenta com parcimônia essa construção.

Essas vilas operárias destinavam-se aos empregados da fábrica têxtil da Brasital, enquanto a Vila Porto Góes - construída no período entre 1924 e 1927 - abrigava empregados da fábrica de papel da empresa. Esta vila reúne 22 casas - de alvenaria de tijolo aparente, reunidas em blocos de 4 ou 5 moradias -, erguidas em torno de um "quintalão". Não há ornatos em suas fachadas, tendo sido adotado um tratamento formal baseado em jogo de volumes e em movimento de telhado.

Nas vilas da Brasital em Salto, o aspecto mais curioso são os chamados "quintalãos". Os de Salto foram os únicos identificados entre as vilas operárias e núcleos fabris pesquisados no Brasil. Entretanto, o quintal coletivo no centro da quadra - mas com forma e uso um pouco distinto - integrou a tradição de núcleos

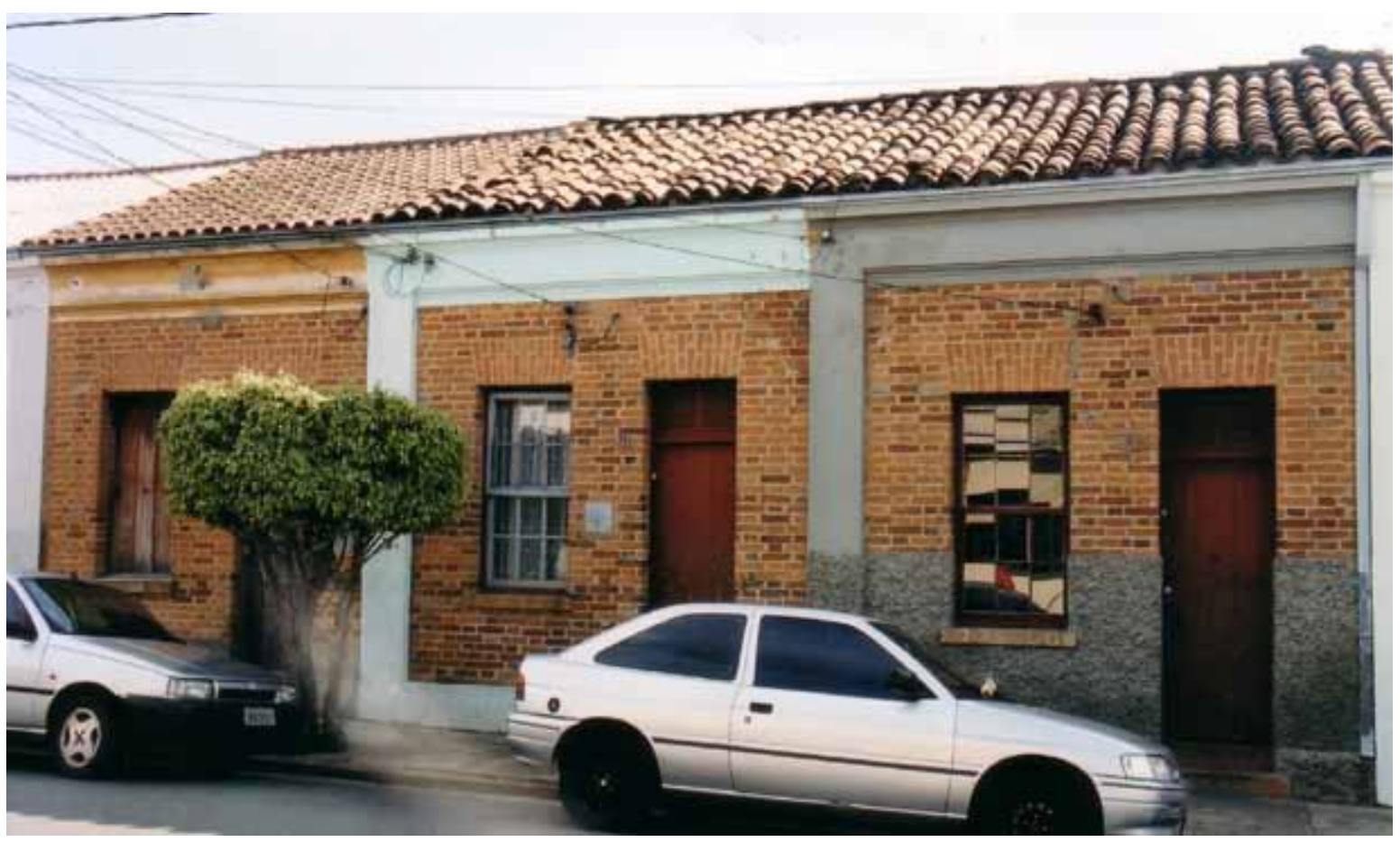

Figura 28 - Vila Brasital, erguida pela Brasital entre 1920 e 1924, em Salto (SP). Fotografia de Philip Gunn, 2001.

Annals of Museu Paulista. v. 19. n.1. Jan.-June 2011. 


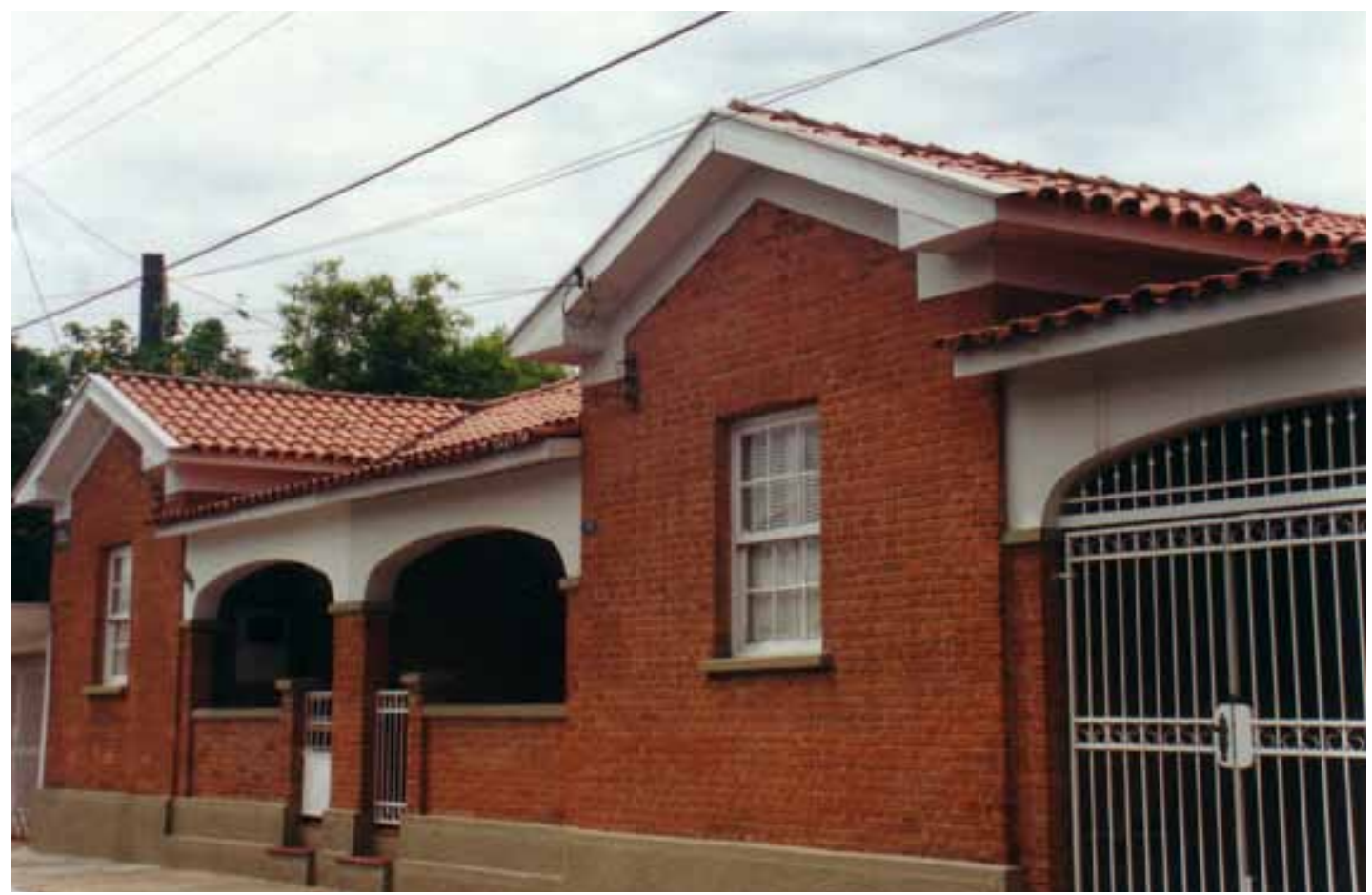

Figura 29 - Vila da Barra do Tietê, erguida pela Brasital na década de 1940, em Salto (SP). Fotografia de Philip Gunn, 2001.

27. Cf.Carla Milano Benclowicz (1989,p.405). fabris ingleses desde a experiência de Port Sunlight e seus allotments, criados na década de 1890.

Em São Roque, junto às suas instalações, a fábrica Brasital construiu duas vilas operárias: uma, provavelmente na década de 1920, reunindo 38 moradias; e outra, possivelmente no início da década de 1940, com cerca de vinte moradias do tipo conhecido no Brasil na época como bangalô. Ambas as vilas são compostas de casas geminadas em tijolo aparente. Nelas os únicos ornatos são faixas em reboco compondo molduras, arquivoltas e cimalhas, sempre em um desenho muito simplificado.

A redução dos ornatos em arquitetura com exterior em tijolo aparente pode ser observada na Vila Cerealina, construída entre 1923 e 1924, pelas Indústrias Reunidas Francisco Matarazzo. Segundo Carla Milano Benclowicz, as casas desta vila voltadas para a Avenida Alvaro Ramos foram projetadas por Giuseppe Chiappori, e as demais, possivelmente pelo engenheiro José Melloni ${ }^{27}$. Confirmando a primazia de tijolo aparente na arquitetura industrial da época, o material surge nas fachadas de todas as casas. A sobriedade da estética fabril é reafirmada em fachadas cujos ornatos são limitados a faixas com acabamento de argamassa (Figura 30).

Outro conjunto industrial edificado com amplo uso de tijolo aparente foi a Tecelagem Parahyba, fundada em 1927, em São José dos Campos (SP). A fábrica foi instalada em galpão cujas fachadas em tijolo aparente são demarcadas 


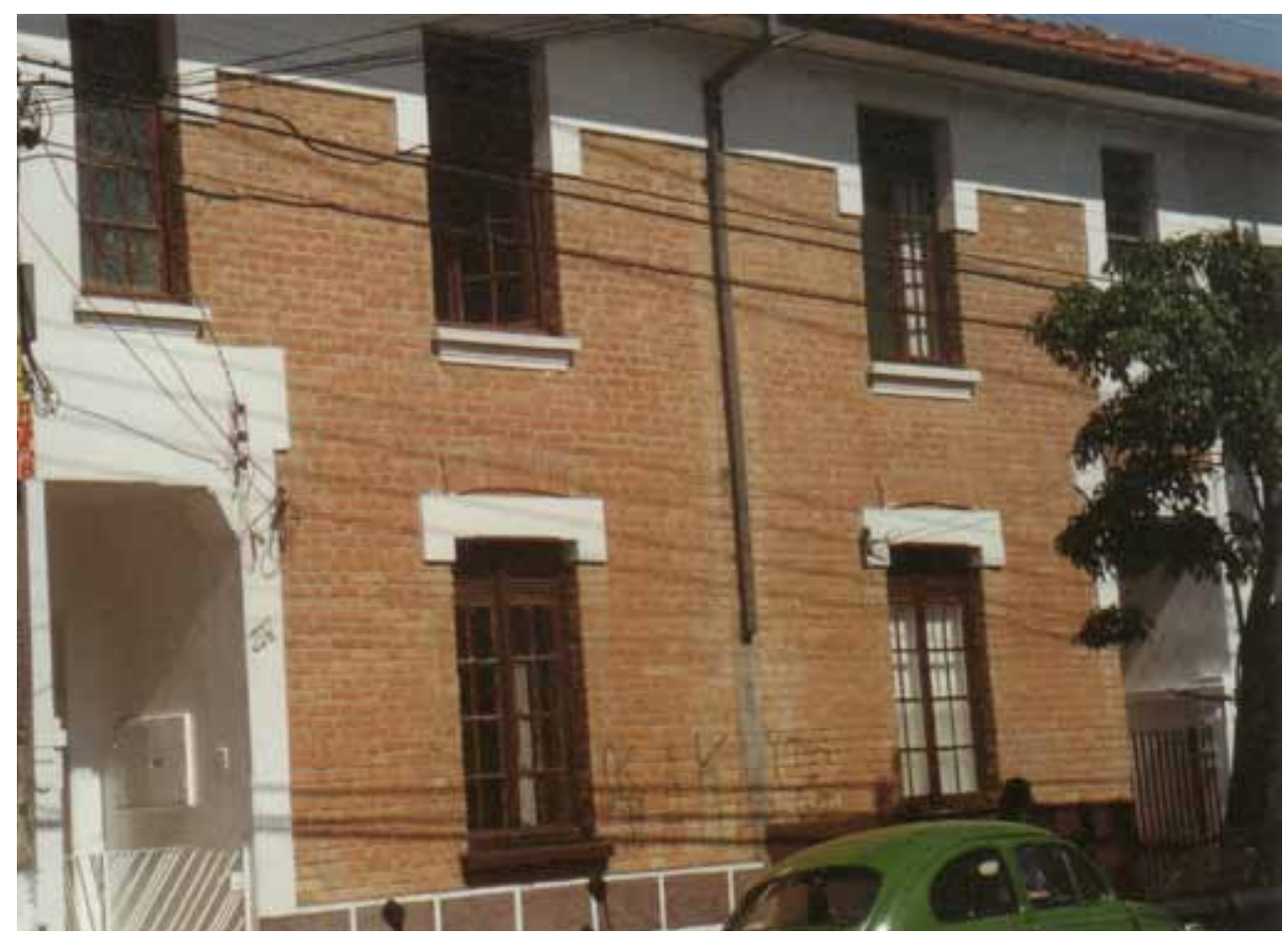

28. Cf. Amélia Panet (2002, p. 41).

Figura 30 - Vila Cerealina, erguida pelas Indústrias Reunidas Francisco Matarazzo, em São Paulo (SP). Fotografia de Philip Gunn, 2001.

por uma sucessão de pilastras que definem o ritmo das aberturas; os únicos ornatos presentes são cimalhas feitas com o mesmo material. Junto às suas instalações fabris, a indústria ergueu vários conjuntos de casas, os primeiros deles foram uma vila operária e um grupo de casas para gerentes junto à fábrica, ambos em tijolo aparente. As destinadas a operários são moradias dispostas em blocos, com fachadas destituídas de ornatos. As moradias destinadas ao proprietário e aos gerentes são casas isoladas, dotadas de jardins, terraços e formas variadas (Figura 31 ).

Em Rio Tinto, núcleo fabril construído na Paraíba entre 1918 e 1948 pela Companhia de Tecidos Rio Tinto, do Grupo Lundgren, a unidade arquitetônica é obtida pela repetição das tipologias habitacionais e pelo amplo uso de tijolo aparente nas construções. O material foi empregado nas instalações fabris (galpões, portarias e chaminés), em prédios de uso coletivo (igreja, escola, hospital, armazém de consumo e clubes), e em moradias (Figura 32). Amélia Panet sugere que o traçado de Rio Tinto e a disposição dos prédios seguiu orientação dos dirigentes da fábrica, em especial do coronel Frederico Lundgren. A autoria dos projetos de arquitetura das construções erguidas neste núcleo fabril é desconhecida.

tijolo aparente foi empregado na mansão dos patrões - um prédio amplo, extremamente sóbrio, conhecido no local como bunker-, na maioria das casas destinadas a mestres e em algumas casas destinadas a operários. No último

Annals of Museu Paulista. v. 19. n.1. Jan.-June 2011. 


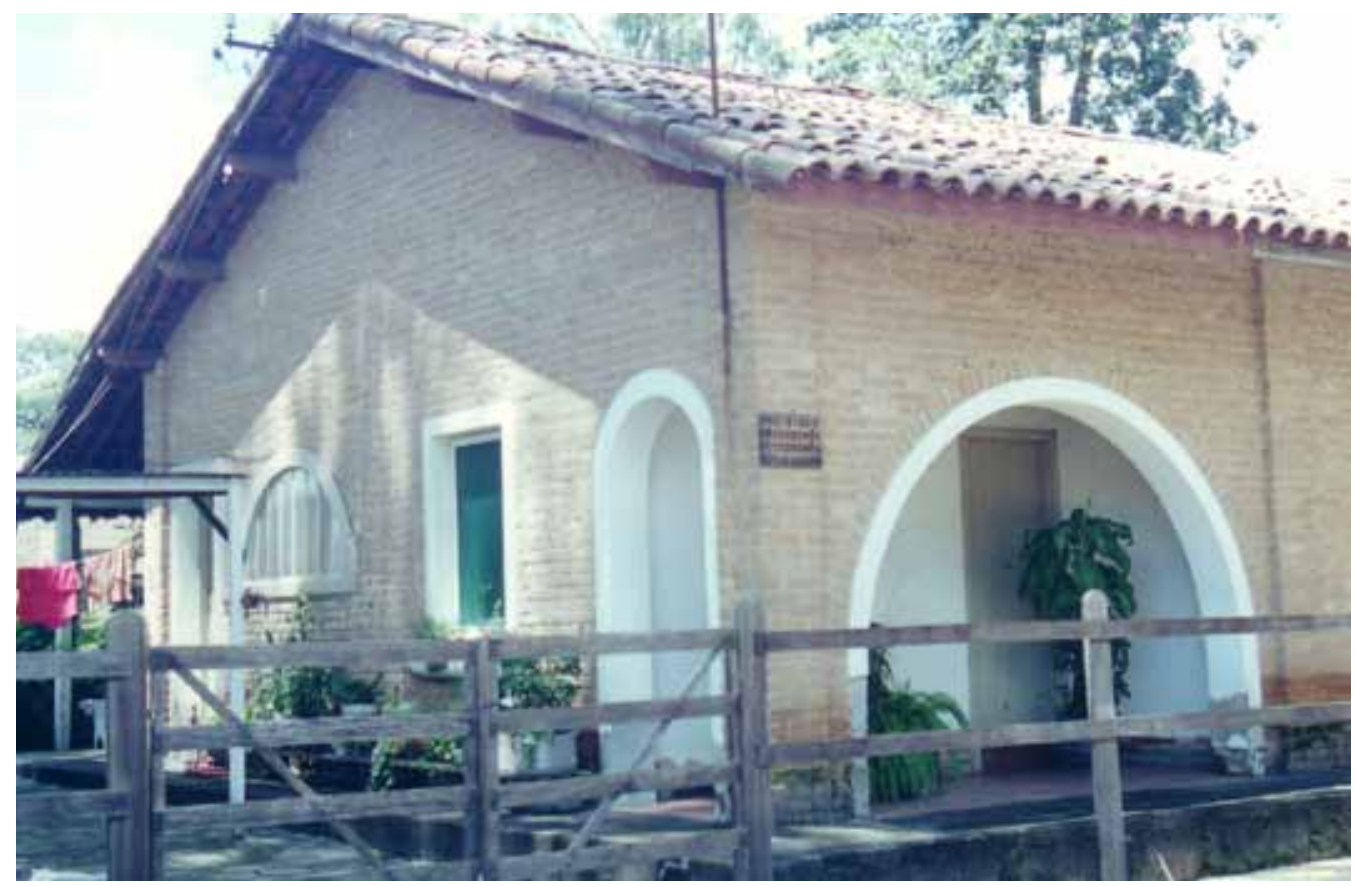

Figura 31 - Casas construídas pela Tecelagem Parahyba, em São José dos Campos (SP). Fotografia de Philip Gunn, 2001.

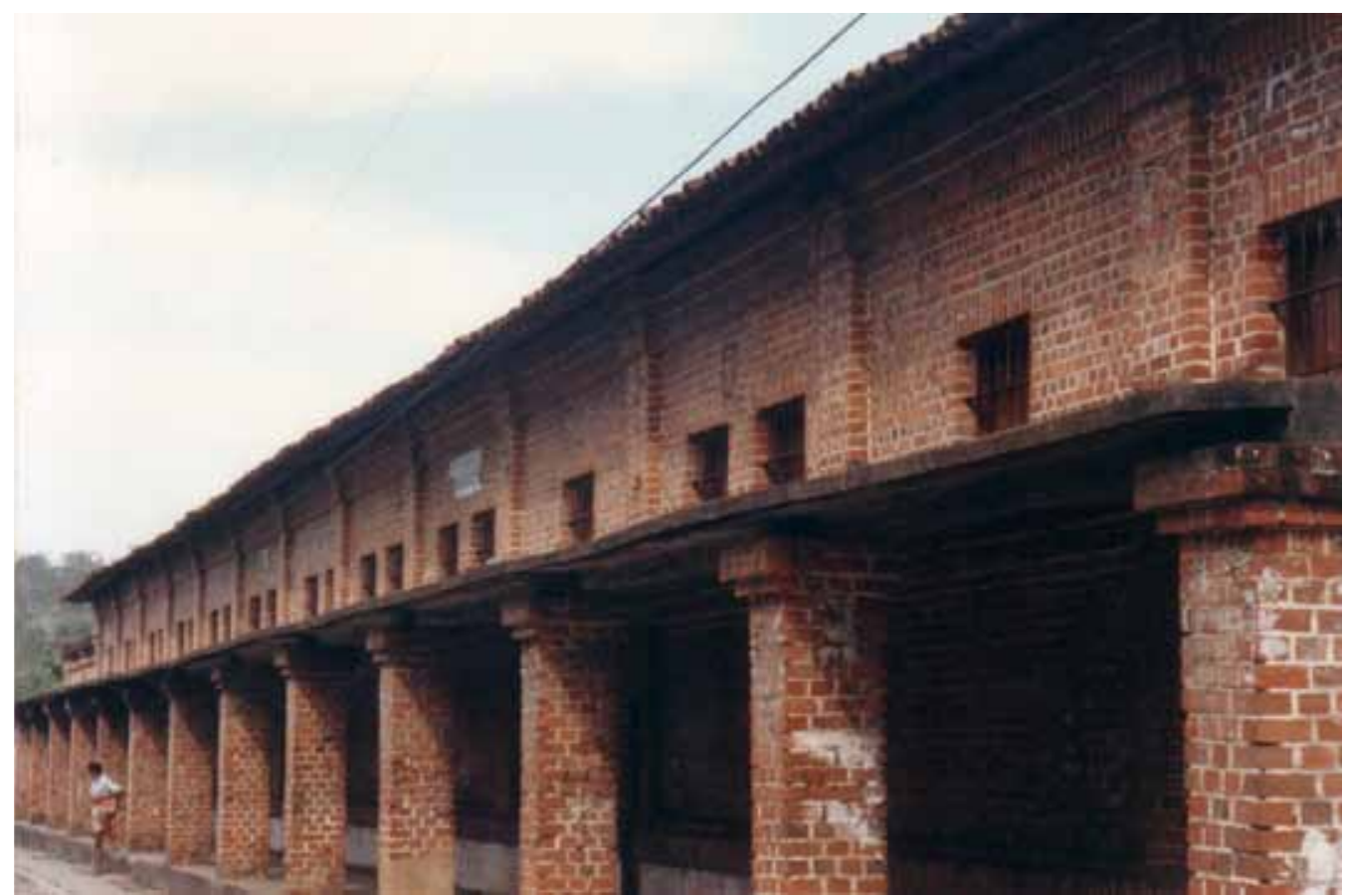

Figura 32 - Fábrica da Companhia de Tecidos Rio Tinto, em Rio Tinto (PB). Fotografia de Philip Gunn, 1996. 
caso, o uso tijolo aparente está ausente das casas de padrão mais simples, surgindo em todos os elementos da fachada nas casas destinadas a mestres, e apenas em pilares ou pilastras em casas geminadas para operários. Assim, contrariando seu uso pouco prestigioso ao começar a ser amplamente empregado no século XIX, em Rio Tinto o uso do tijolo aparente distingue exatamente as construções de maior prestígio (Figura 33).

Nos prédios de uso coletivo - igreja, clube, cinema, armazém de consumo e delegacia -, o tijolo aparente compõe fachadas que conciliam uma estética industrial despojada, com tendências Art déco. Nestes prédios, motivos do vocabulário arquitetônico do Art déco - formas escalonadas, sobreposição de planos de fachadas, apliques na alvenaria e acessos principais assinalados por elementos como marquises e pórticos - e a métodos de composição beaux-arts simetria e hierarquia na organização do projeto -, são qualificados pelo uso amplo e peculiar de tijolo aparente. Aplicado em todos os elementos da fachada, inclusive nos apliques ornamentais, este material imprime às construções um tipo de despojamento e um senso de rigor, claramente vinculado aos valores que regiam o trabalho e o cotidiano local.

Algumas dessas construções, como a lgreja de Santa Rita de Cássia (construída em 1923 e ampliada em 1945), o Cine Orion (1944) e o Clube da Vila Regina são particularmente expressivas. No prédio do armazém de consumo,

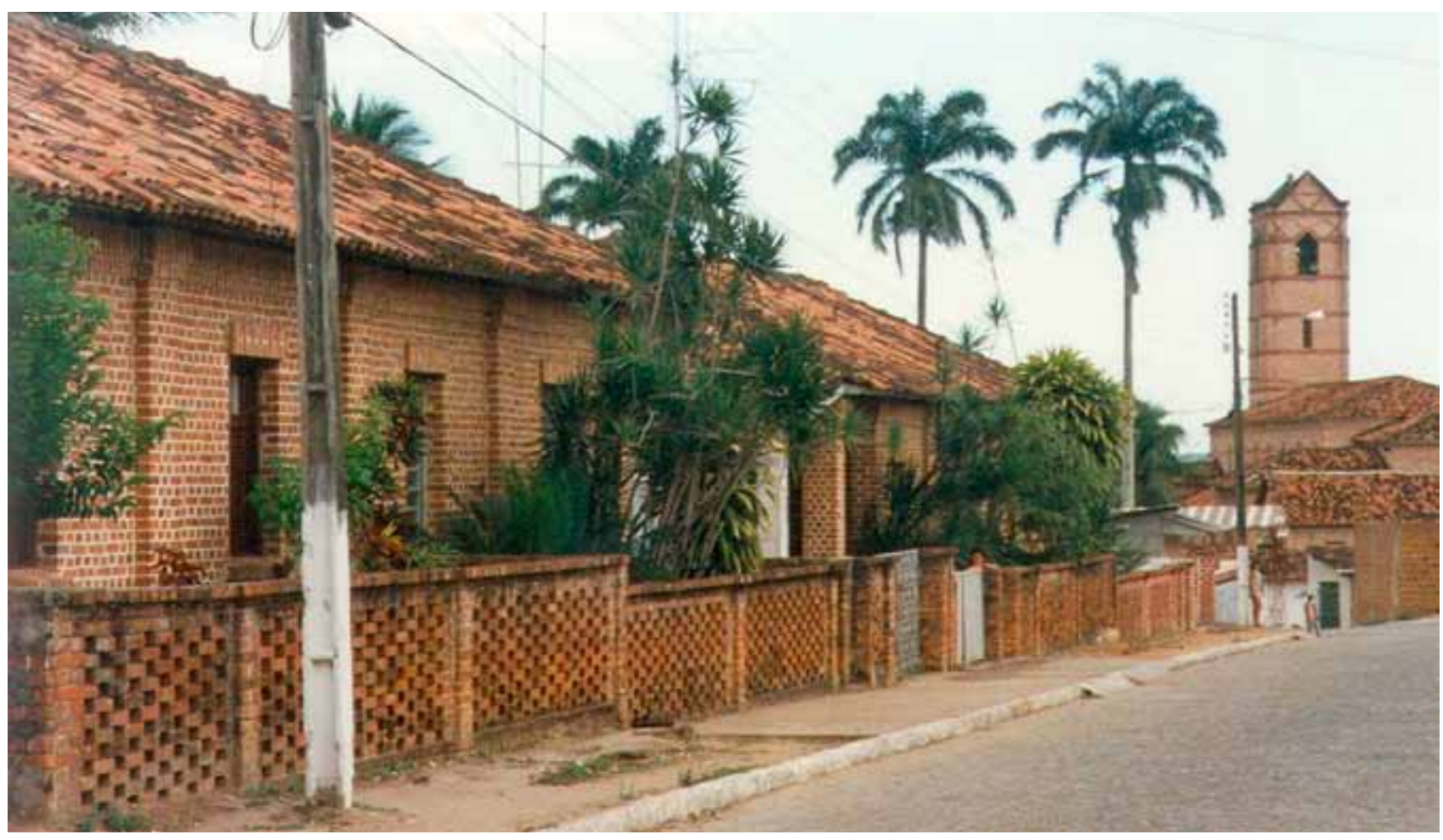

Figura 33 - Moradias para mestres e operários, edificadas pela Companhia de Tecidos Rio Tinto, em Rio Tinto (PB). Fotografia de Philip Gunn, 2002. 
29. Cf. Geraldo Gomes (1987, p. 200).
- gosto déco se expressa na forma escalonada da platibanda, na sobreposição de planos de fachada e na marquise assinalando a entrada. No cinema a composição da fachada concilia um escalonamento típico do déco, com discretos ornatos em brickwork. Nos prédios da delegacia e do clube da Vila Regina, pórticos assinalam o acesso, dominando composições orientadas pela simetria e uso escalonado de elementos (Figuras 34 a 36).

A igreja é uma edificação expressiva, que concilia simplicidade, sobriedade e requinte, celebrando uma estética fabril trabalhada com recursos do vocabulário Art déco. Trata-se de uma composição de volumes escalonados, dominada por uma torre central que assinala o acesso principal. Aberturas delgadas - os vitrais e os vãos vazados da torre - contribuem para enfatizar a verticalidade do prédio. Desenhos e faixas em brickwork - exploram as possibilidades ornamentais do tijolo, que também desenha o rasgo na torre. A igreja de Santa Isabel, em Paulista - outro núcleo fabril criado pelo Grupo Lundgren, em Pernambuco -, é também uma construção em tijolo aparente, neste caso remetendo a motivos do estilo românico. Tem estrutura de concreto armado. Foi projetada pelo arquiteto Munter - também autor do projeto da Catedral de Fortaleza e da Capela do Seminário de Garanhuns - e construída entre 1940 e 195029. Em Paulista, o tijolo é delicadamente trabalhado em arcos, vitrais geminados, absidíolas, pilastras e coruchéu octogonal, elementos que suavizam sua aparência e conferem sofisticação ao uso do material. Em Rio Tinto, ele é trabalhado em linhas paralelas, formas angulosas e ortogonais, resultando numa composição austera, de forte expressividade (Figuras 37a-37c).

Em construções posteriores erguidas em Rio Tinto - como a portaria da fábrica -, o tijolo aparente persiste, agora integrando composição filiada ao Estilo Internacional de arquitetura moderna.

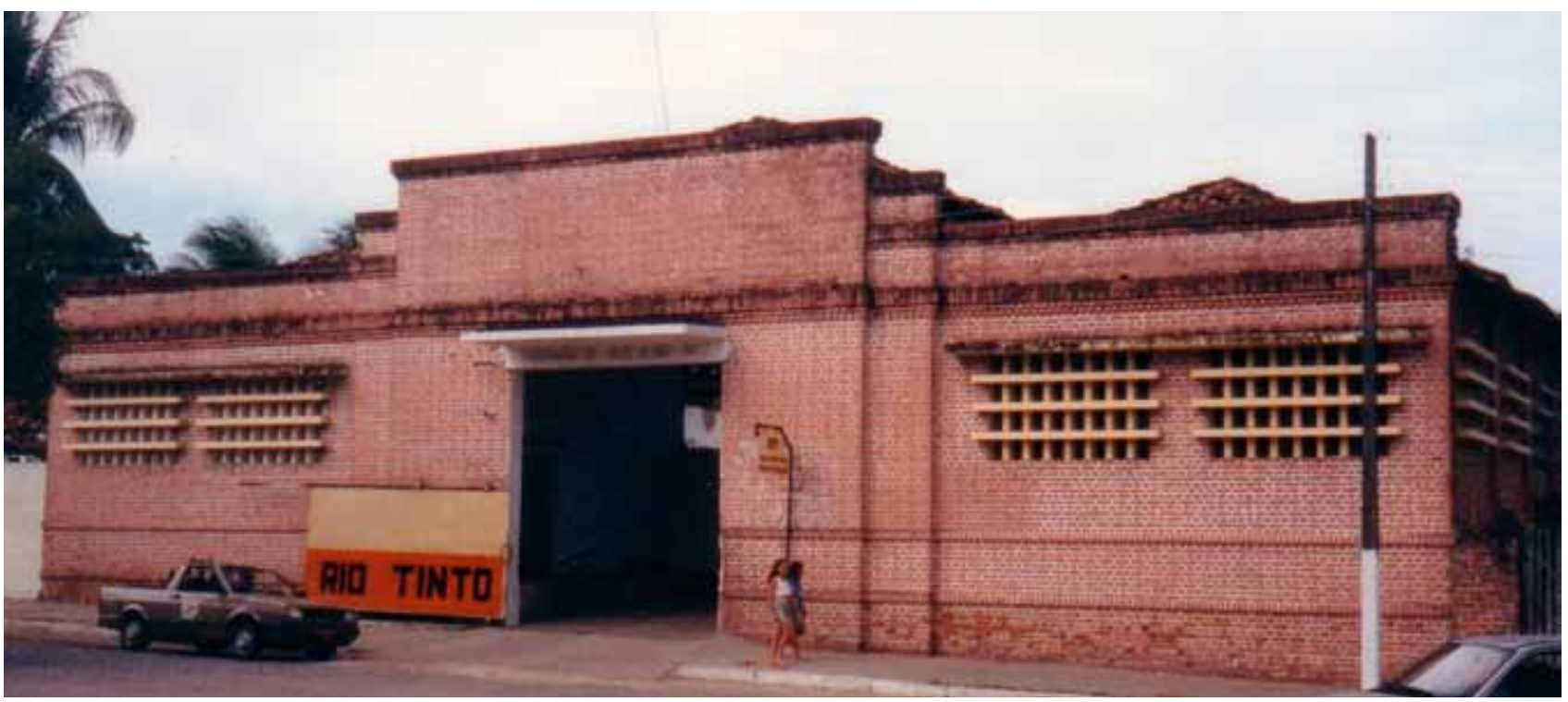

Figura 34 - Prédio do armazém de consumo, em Rio Tinto (PB). Fotografia de Philip Gunn, 2002. 


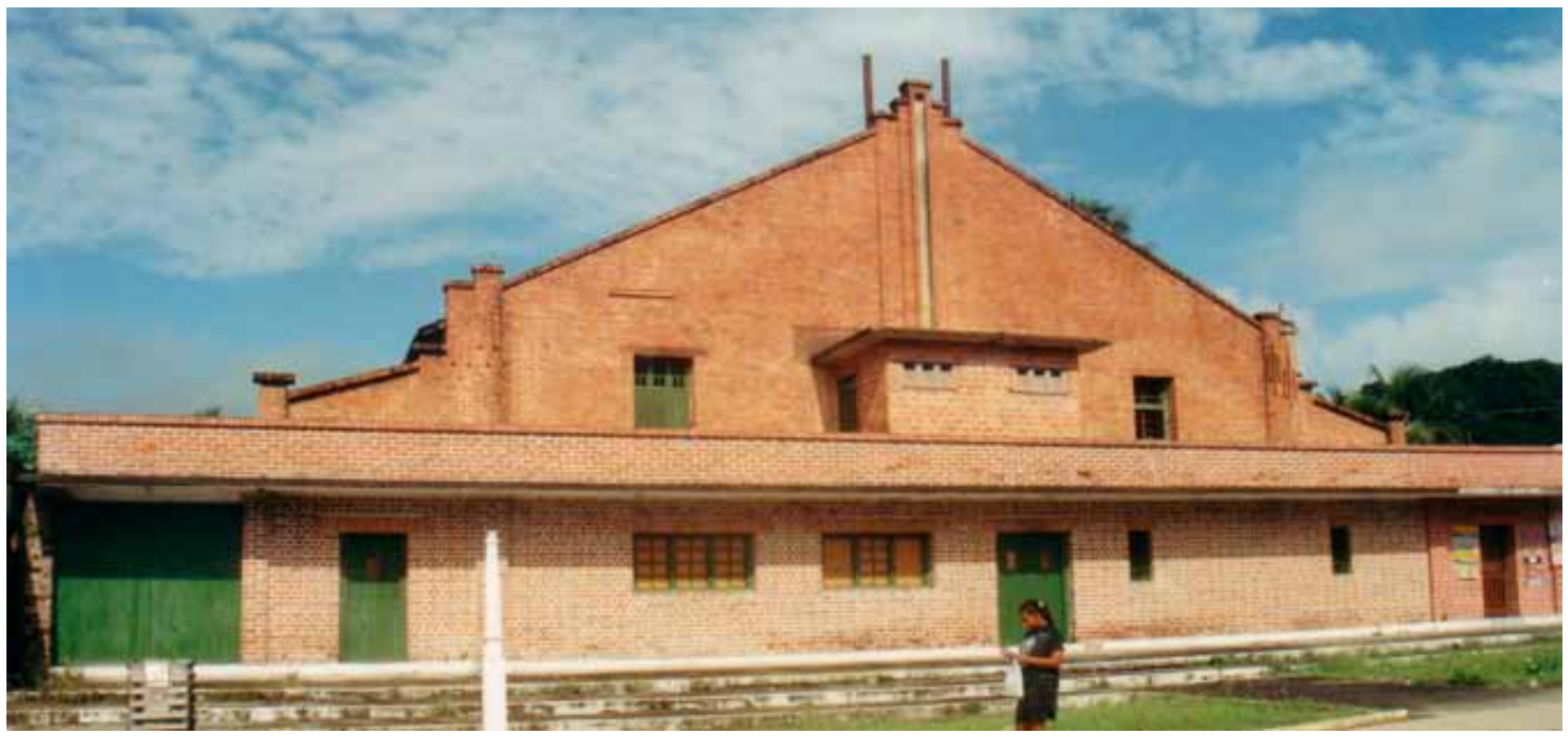

Figura 35 - Prédio do cinema, em Rio Tinto (PB). Fotografia de Philip Gunn, 2002.

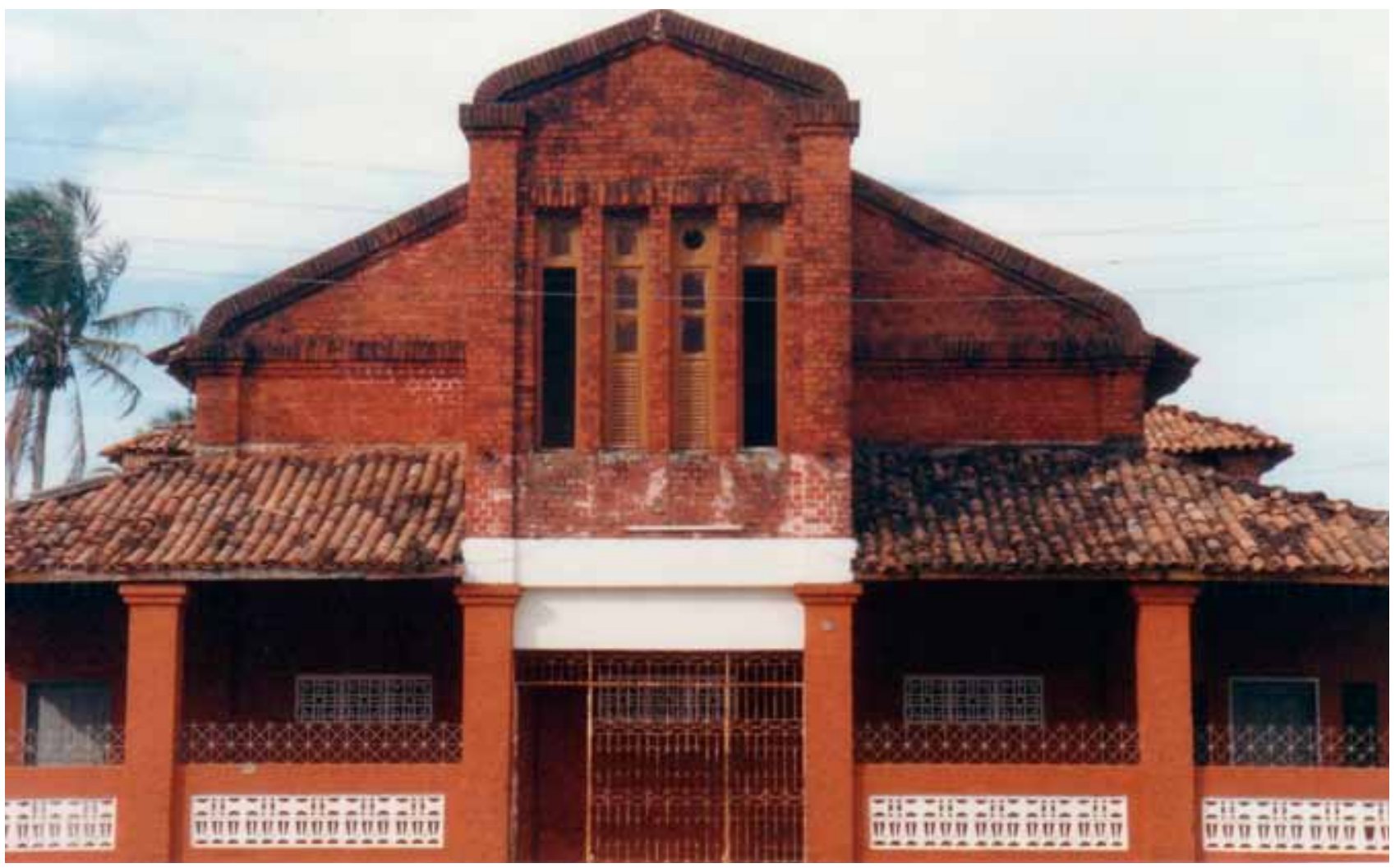

Figura 36 - Prédio do Clube da Vila Regina, em Rio Tinto (PB). Fotografia de Philip Gunn, 1996. 


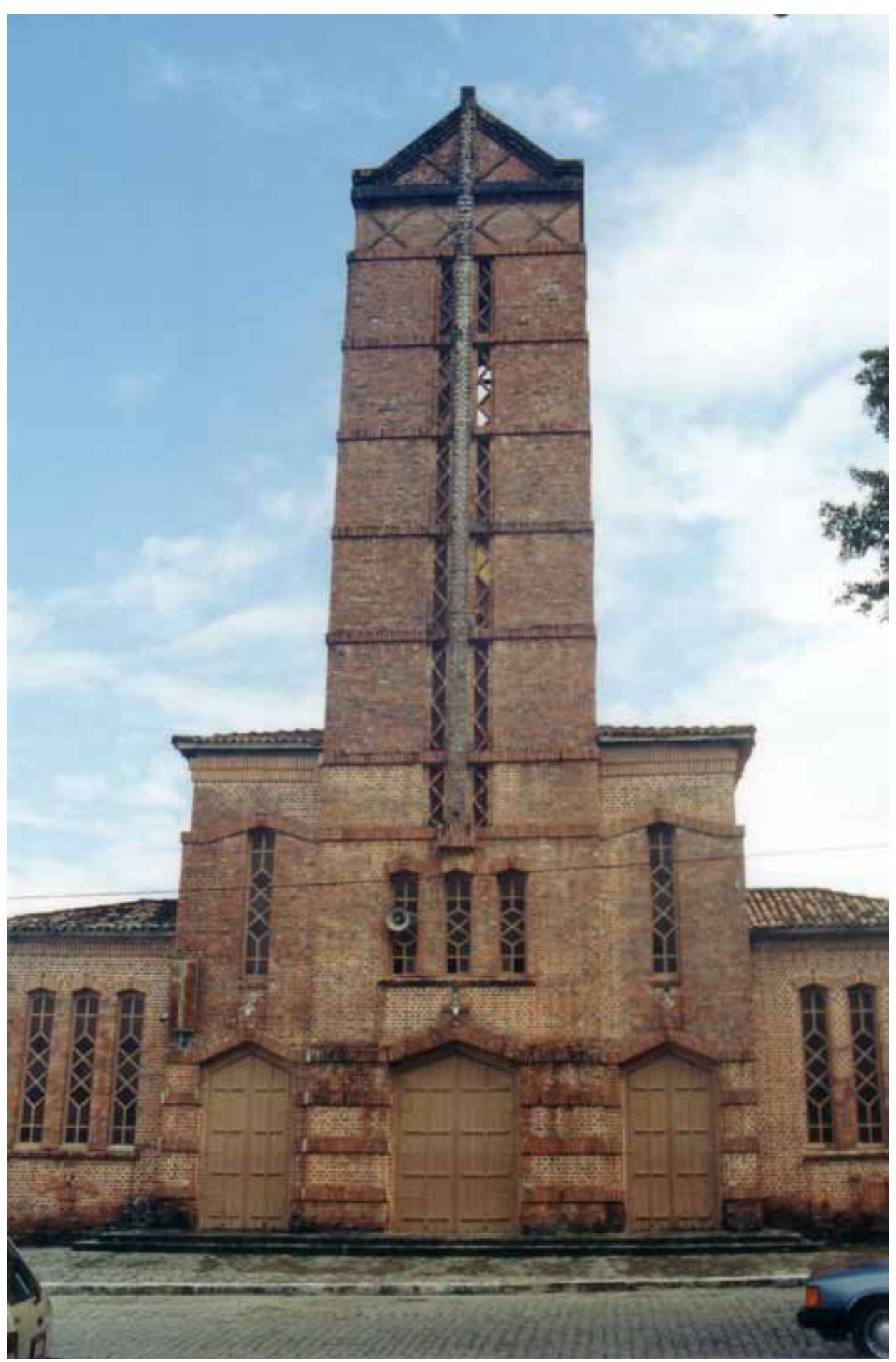

Figura 37a - Igreja em Rio Tinto (PB). Fotografia de Philip Gunn, 1996. 


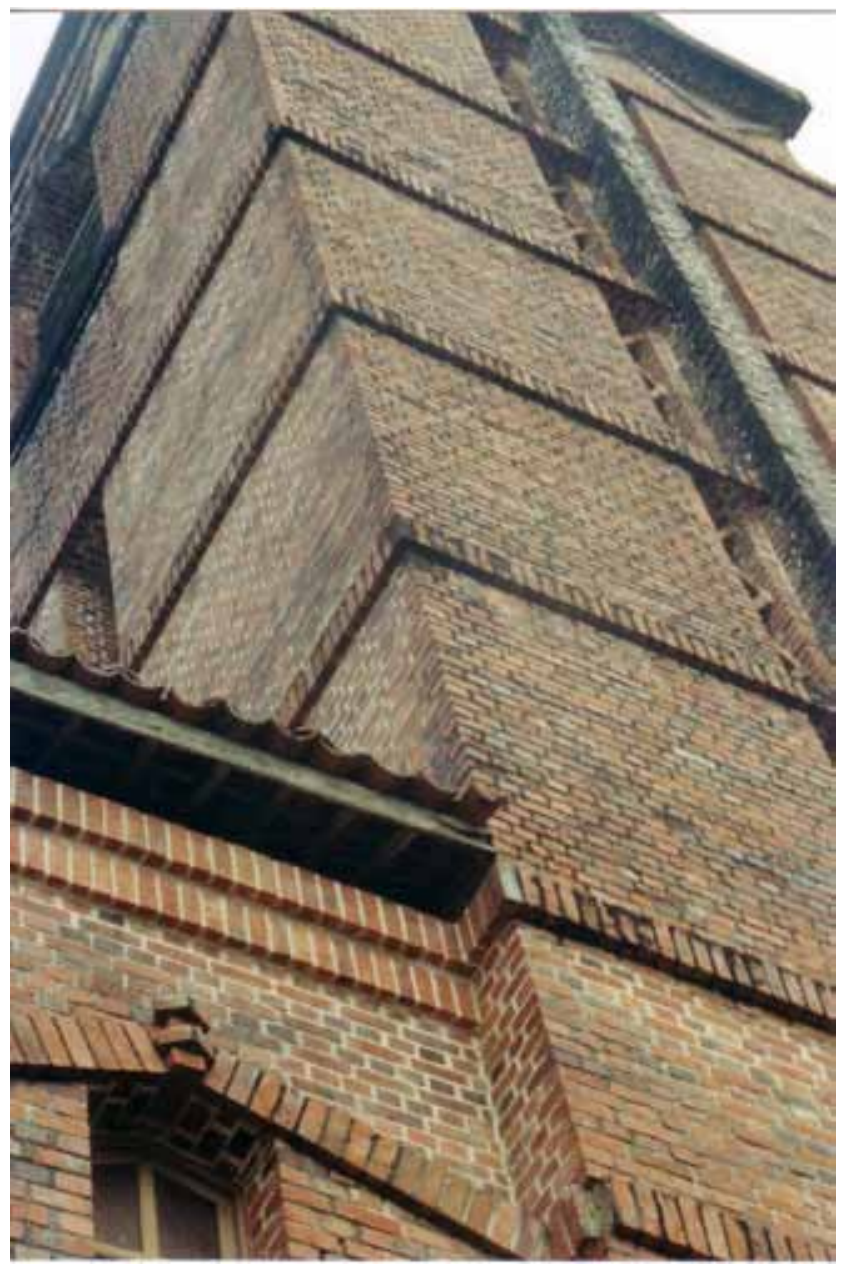

Figura 37b - Igreja em Rio Tinto (PB).

Fotografia de Philip Gunn, 2002.

Figura 37c - Igreja em Rio Tinto (PB). Fotografia de Philip Gunn, 2002.

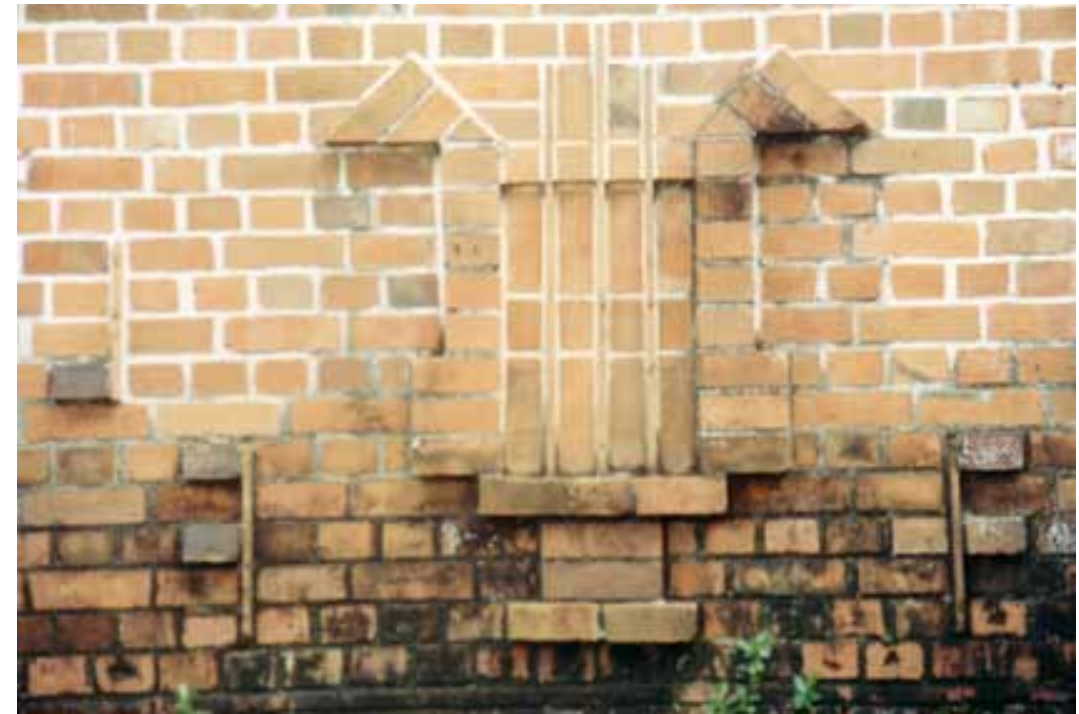

Annals of Museu Paulista. v. 19. n.1. Jan.-June 2011. 
Em Caieiras (SP) - núcleo fabril criado pela Companhia Melhoramentos -, o tijolo aparente foi empregado nos fornos de cal construídos em 1877 e, na década seguinte, no prédio da cerâmica, enquanto a fábrica de papel era erguida em pedra. Na década de 1940, o tijolo aparente foi amplamente utilizado em casas construídas para operários.

Nessa década o material surge em igreja e escola da Vila Rhodia, um núcleo fabril em Paulínia (SP). São construções que, de uma forma muito simplificada, reeditam o procedimento (usual em conjuntos fabris erguidos nas últimas décadas do século XIX e primeiras do XX) de conciliar o uso de tijolo aparente com composições e motivos inspirados em estilos do passado. A igreja - dotada de vãos em arco pleno, vitrais geminados, óculo, torre sineira lateral e contrafortes - remete, de uma forma muito livre, à linguagem românica. $\mathrm{Na}$ escola, também de forma bastante livre, motivos da linguagem clássica se expressam no pórtico com frontão e arcadas.

Nota-se como, no cenário fabril brasileiro, o uso do tijolo aparente ampliou-se progressivamente, tornando-se característico do despojamento que baliza a nova paisagem industrial. No período considerado, essa ampliação do uso verificou-se em dois sentidos: por um lado, nas construções industriais, uma tendência foi seu uso estender-se, de alguns elementos utilitários ou ornamentais, para recobrir fachadas inteiras. Por outro, seu uso eventualmente se estende, dos galpões industriais, para outras construções, como casas, igrejas, cinemas, escolas etc.

A maneira de empregar o tijolo aparente está condicionada ao uso dos prédios. Assim, em fachadas principais de fábricas, equipamentos de uso coletivo e moradias destinadas a industriais e a funcionários graduados, o tijolo aparente surge, frequentemente, em composições ornamentadas e ainda atreladas à linguagem clássica. Nelas, o material, eventualmente, compõe elementos que remetem a frontões, cornijas, pilastras, frisos e cercaduras, e tem suas possibilidades estéticas amplamente exploradas em trabalhos de brickwork. Nas fachadas de moradias destinadas a operários, a tendência é no sentido de simplificar ou eliminar os elementos decorativos, antecipando uma orientação que, a partir de meados do século XX, vai tender a generalizar-se nas construções de tijolos aparentes erguidas por indústrias.

\section{Ornatos referentes ao mundo fabril: a Vila Maria Zélia e outros exemplos}

Construídas pelas fábricas, para trabalhadores, no início do século XX, as casas geminadas mostradas nas Figuras 38-39 têm nas fachadas uma ornamentação despojada, constituída por pilastras e molduras. Apesar da filiação clássica desses elementos, a forma como estão desenhados segue lógicas diversas: na vila operária de Bangu ainda é possível - apesar de toda a simplificação operada - identificar claramente os motivos clássicos (Figura 38). Em Camaragibe (PE), a geometria simples das formas repetidas com regularidade sinaliza o produto de uma era maquinal (Figura 39). 


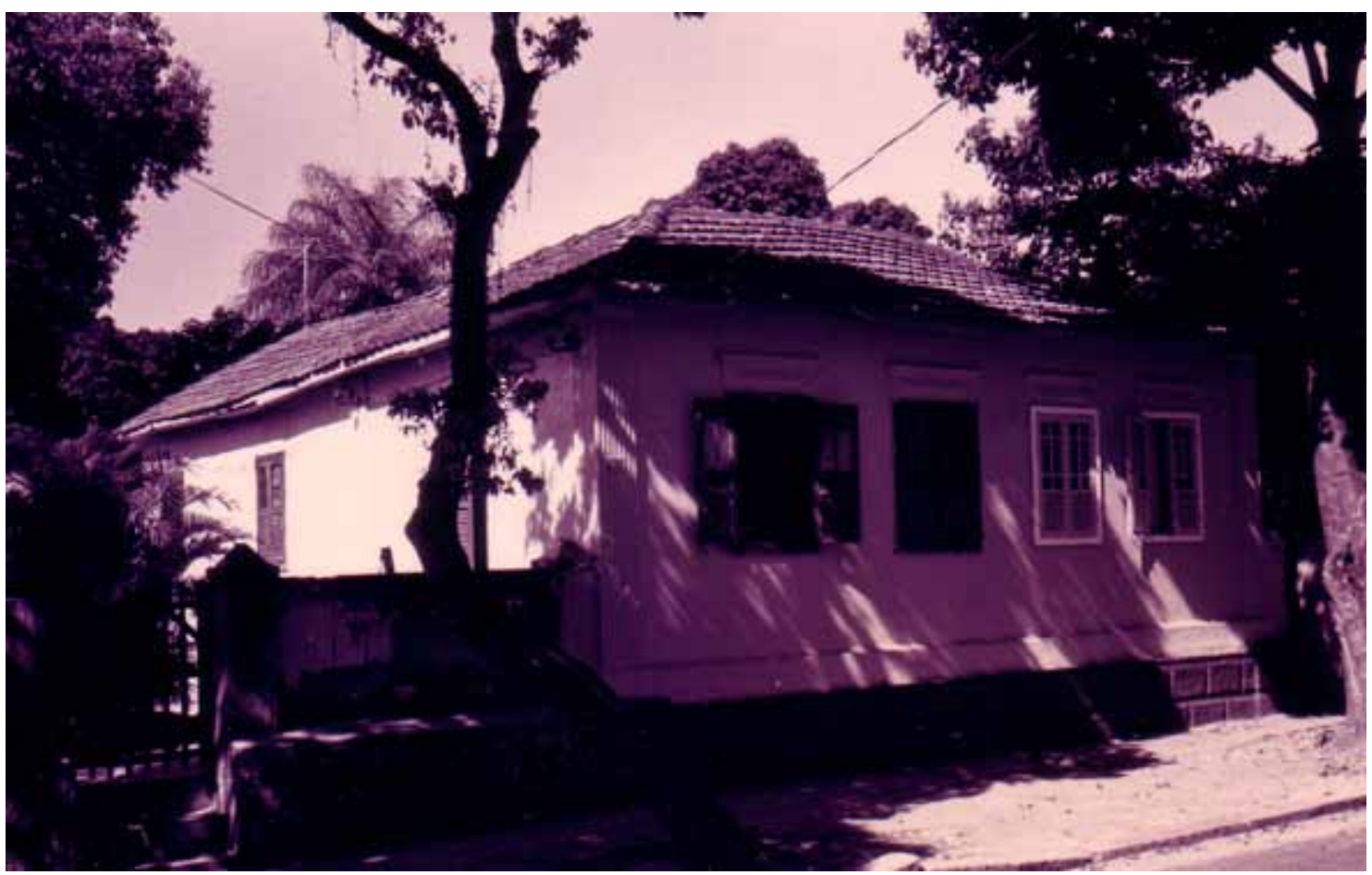

Figura 38 - Casas na vila operária da Companhia Progresso Industrial do Brasil, no bairro de Bangu, Rio de Janeiro (RJ). Fotografia de Philip Gunn, 1996.

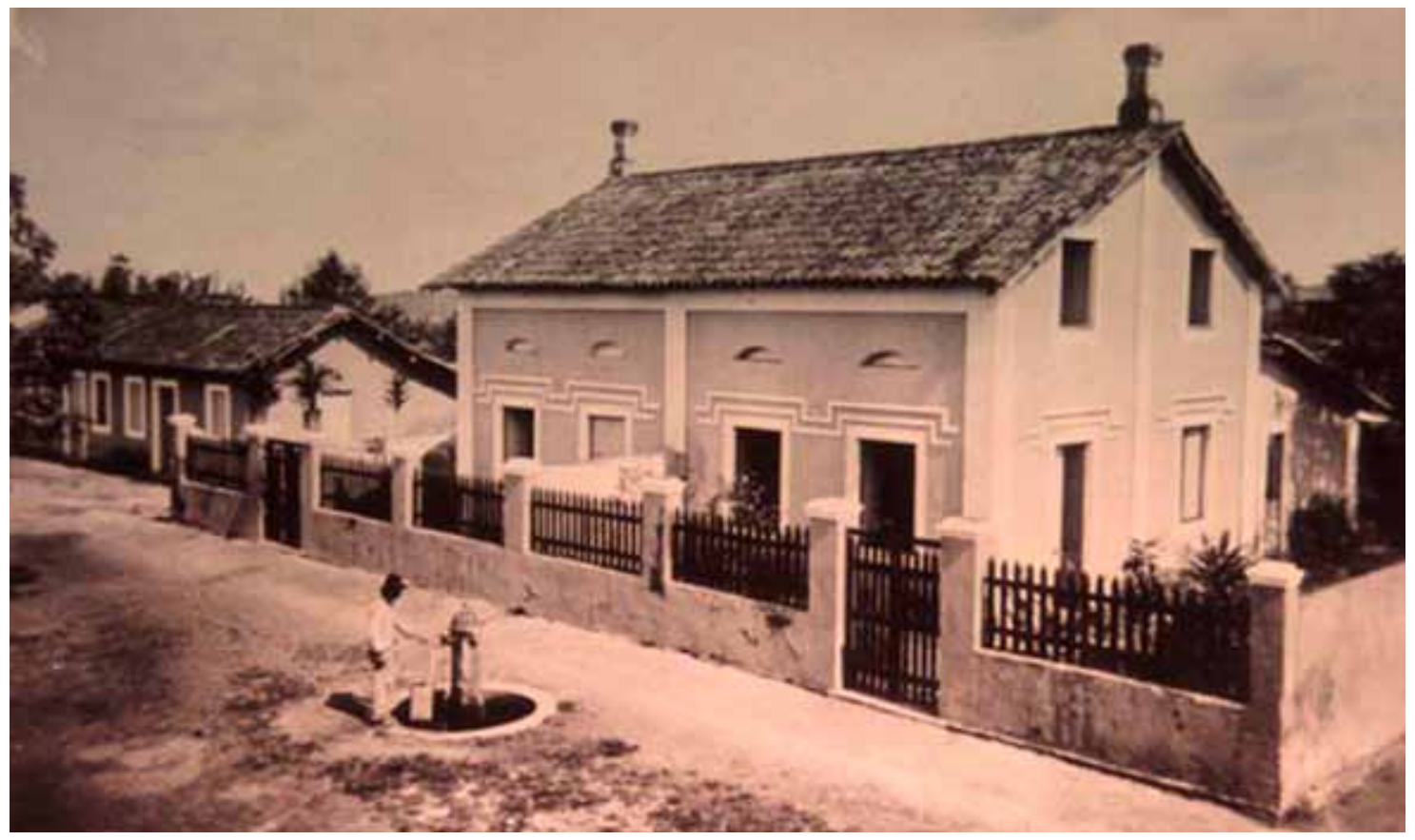

Figura 39 - Casas em Camaragibe (PE). Fonte: FUNDAJ. 
30. Cf.Alfredo Cusano (1980,p 448-450)

\section{Idem, p. 461.}

32. Cf.EvaA.Blay (1985, p.225); e Palmira P.Teixeira (1990, p. 75)
Em alguns casos raros, a estética industrial expressou-se na arquitetura de vilas operárias de forma ainda mais explícita, usando de ornatos cujos temas remetem ao mundo das máquinas. Um exemplo nesse sentido é a igreja da vila operária do Cotonifício Othon Bezerra de Mello S.A., construída no Recife (PE), na década de 1940. Trata-se de uma igreja ampla, coerente com as dimensões da vila (que teria alcançado cerca de 500 moradias). Sua fachada principal, de linhas vagamente inspiradas no estilo românico, é quase destituída de ornatos. Nela, o que surpreende são os dois óculos, cujos desenhos se inspiram em engrenagens industriais (Figura 40).

Embora não tão eloquente, outro exemplo de ornamentação inspirada em motivos industriais é o de algumas das casas da vila operária da Companhia Industrial São Joanense, em São João del-Rei (MG). Nelas, a platibanda é decorada com elementos em relevo que sugerem placas, engrenagens e parafusos (Figura 41).

Entretanto, entre as vilas operárias e núcleos fabris do Brasil, o exemplo mais notável de emprego de ornatos inspirados em motivos do mundo fabril é provavelmente a Vila Maria Zélia. Essa vila operária foi erguida entre 1916 e 1920, na cidade de São Paulo, pelo médico e industrial Jorge Street (18631938), junto à fábrica da Companhia Nacional de Tecidos de Juta. Tinha 176 casas, duas escolas, creche, jardim de infância, parque, salão de festas, sede de associação de operários e escoteiros, campo de futebol, igreja, armazém de consumo, restaurante, alojamento para solteiros, gabinete médico e farmácia. Confinada no interior de espaço murado, na periferia da cidade, esta vila surgia como um protótipo do cotidiano operário protegido e controlado, postulado por industriais da época. Na vila moravam operários e, em casas maiores, funcionários mais graduados como, por exemplo, um dos médicos contratados pela fábrica para atender no posto de saúde existente. Junto ao prédio que abrigava a administração da fábrica, foi construída ainda uma ampla residência de dois pavimentos destinada ao seu gerente.

Em seus primeiros anos de existência, a vila foi visitada por Alfredo Cusano. Em relatos de 1912, suas descrições das moradias, e do interior da creche e das escolas, enfatizam a higiene, o asseio, a ordem e a comodidade ${ }^{30}$. Para o observador, as moradias operárias

são verdadeiros chalés, com seus jardizinhos floridos e quintalzinhos, água filtrada, luz elétrica e chuveiros. Casinhas que não seriam desprezadas, iá não digo pelos operários de outras fábricas, mas por pequenos burgueses, que pagam o quádruplo ou o quíntuplo de aluguel, sem ter a graciosa moradia que possuem os afortunados operários da fábrica "Maria Zélia"31.

Os projetos da fábrica (construída em 1913) e de parte da vila operária laquela construída entre 1913 e 1919, isto é, excetuando os chalés edificados em 1920) são atribuídos por algumas autoras ao arquiteto francês Pédarieux ${ }^{32}$. Carla Milano Benclowicz, embora também aponte esse arquiteto como possível autor do projeto da Vila Maria Zélia, mostra que o projeto da Fábrica Maria Zélia foi elaborado em Bradford, Inglaterra, em 1912, pela Chas. 


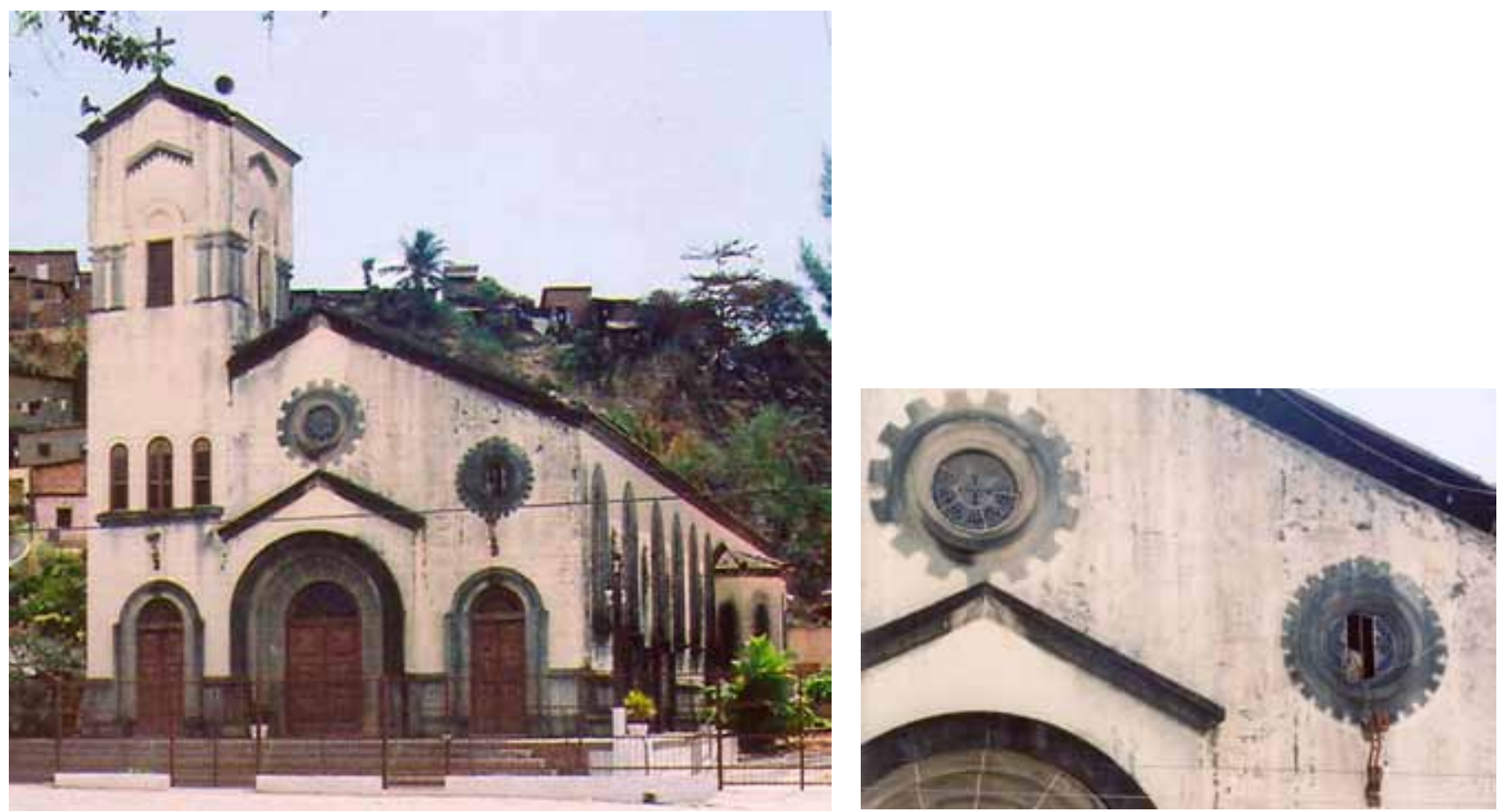

Figura 40 - Igreja da vila operária do Cotonifício Othon Bezerra de Mello S.A., no Recife (PE). Fotografias de Philip Gunn, 2000.

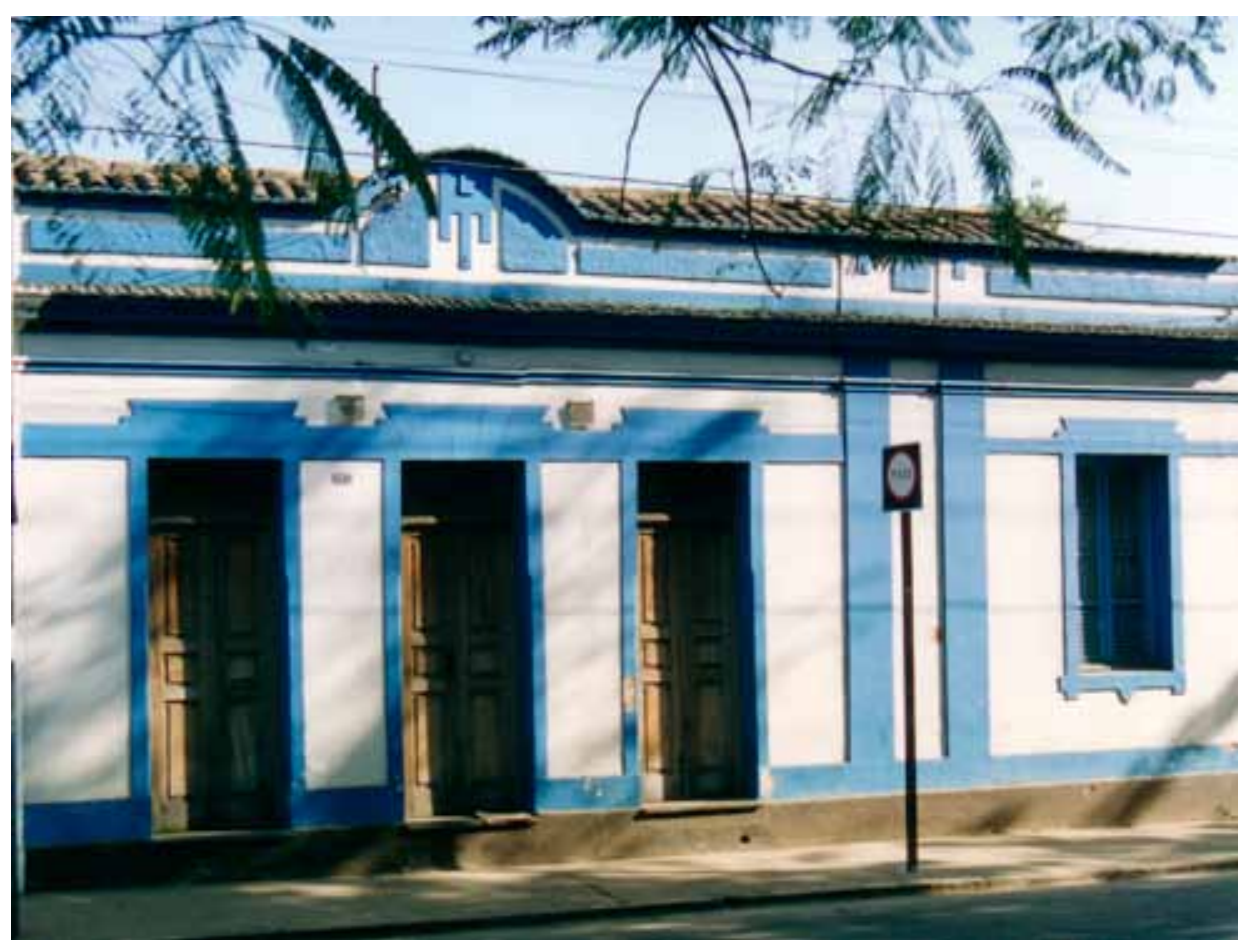

Figura 41 - Vila operária da Companhia Industrial São Joanense, em São João del-Rei (MG). Fotografia de Philip Gunn, 1998. 
33. Cf.Carla Milano Benclowicz (1989,p. 343,344,367).

34.VerTelma de Barros Correia (1998).

35. Cf.Carla Milano Benclowicz (1989,p.344).

36. Ibidem.

37. Este procedimento de sugerir pilastras parcialmente ocultas foi utilizado pela primeira vez no século XVI, na fachada da igreja de Gesú, em Roma, projetada porVignola\ Summerson (1994, p.65).
Hahlo \& Sons, e sugere que a vila operária teria se inspirado em Saltaire, um núcleo fabril erguido pelo industrial têxtil Titus Salt, em 1851, próximo àquela cidade ${ }^{33}$. Projetado pelos arquitetos Henry Lockwood e William Mawson, Saltaire foi um núcleo fabril modelo na Inglaterra do século XIX, seja pela amplitude das dimensões e dos serviços oferecidos, seja pela qualidade dos espaços livres e construídos, e pelo requinte da arquitetura produzida ${ }^{34}$. Entre a Vila Maria Zélia e Saltaire, semelhanças podem ser localizadas no traçado ortogonal das vias e na concentração espacial de prédios de uso coletivo. Há, entretanto, grandes diferenças, tanto em termos da dimensão do conjunto e de seu programa, quanto no que diz respeito à arquitetura. Em Saltaire, a fachada da maioria das construções - inclusive as moradias, a fábrica, a igreja metodista e o hospital concilia uma sóbria arquitetura de pedra com detalhes do vocabulário românico, usados, sobretudo, no desenho de janelas e portas. Na Maria Zélia, elementos desse vocabulário são identificados apenas na igreja, e com um resultado bem diferente.

Os prédios da Vila Maria Zélia foram edificados com alvenaria de tijolo revestido com cimento e pó de pedra. Na maioria das casas, utilizaram-se telhas planas de cimento amianto, importadas da Inglaterra, com aparência semelhante a telhas de ardósia ${ }^{35}$. No Memorial descritivo dos chalés, de 1920, informa-se que serão usadas telhas de barro do tipo Marselha, que todos os cômodos - exceto cozinha e despensa - terão forro de madeira, e que o piso será de madeira ou - nas áreas "molhadas" - de ladrilho de cimento ${ }^{36}$.

Na entrada da Vila, foi criado um pequeno parque e, junto a ele, foi disposta uma igreja, ladeada por prédios que abrigam comércio e equipamentos coletivos (armazém, loja de tecidos, barbearia, farmácia, clube e restaurante). As escolas e as moradias foram situadas em ruas retas com calçadas (embora inicialmente não pavimentadas), gerando uma malha ortogonal, dotada de infraestrutura urbana.

Os prédios de uso coletivo - as duas escolas, a igreja e as duas construções que abrigavam comércio e serviços - destacavam-se do conjunto pelas dimensões e por um maior requinte construtivo.

Os prédios do armazém e do restaurante têm a entrada principal voltada para uma das quinas do lote - que surge chanfrada -, recuperando uma implantação que se tornou muito usual no período abordado. Ainda podem ser identificados, neles, resquícios do esquema de ordens da linguagem clássica: pilastras demarcam o ritmo entre os vãos, às vezes substituídos por estreitos nichos; e os dois pavimentos são claramente demarcados por faixa estreita entre o térreo e o primeiro andar. Uma vez demarcados, eles são tratados de forma hierárquica: as pilastras se estreitam no pavimento superior; no térreo, as vergas são em arco abatido e, no pavimento superior, são retas; no térreo, as paredes são decoradas com desenho no reboco, sugerindo uma rusticação estilizada. Tal desenho, ora é obtido por uma sobreposição de planos - que junto às pilastras sugere haver pilastras parcialmente ocultas umas atrás das outras ${ }^{37}$-, ora é gerado pela criação de linhas em baixo-relevo. No pavimento superior, a decoração torna-se um pouco mais densa, com balcão dotado de balaustrada (assinalando o acesso principal) 
e cornija dotada de dentículos sob a platibanda. Nele, o motivo principal da decoração é uma delicada sobreposição de planos. Distante dos motivos inspirados na natureza - flores, animais, figuras humanas etc. - e das ânforas e compoteiras tão caras ao ecletismo, notam-se nesse jogo geométrico de planos, e no tratamento ornamental das balaustradas e dos consolos do balcão, motivos que remetem à precisão e à sobriedade do mundo das máquinas (Figura 42).

Os prédios das duas escolas - para meninos e para meninas - são semelhantes e voltam-se um para o outro. Neles, a composição clássica evidenciase na organização simétrica dos dois prédios, entre si e entre suas partes específicas, bem como na hierarquia entre os andares - com o superior um pouco mais decorado -, e também na ênfase no acesso principal, na presença de frontão cimbrado e na rusticação estilizada da alvenaria. A junção entre elementos do vocabulário clássico e formas inspiradas em máquinas também se evidencia nesses prédios. Neles, o motivo principal da decoração da alvenaria é uma delicada sobreposição de planos que, como nos prédios do armazém e do restaurante, sugerem chapas de metal. $\bigcirc$ desenho do consolo que apoia a

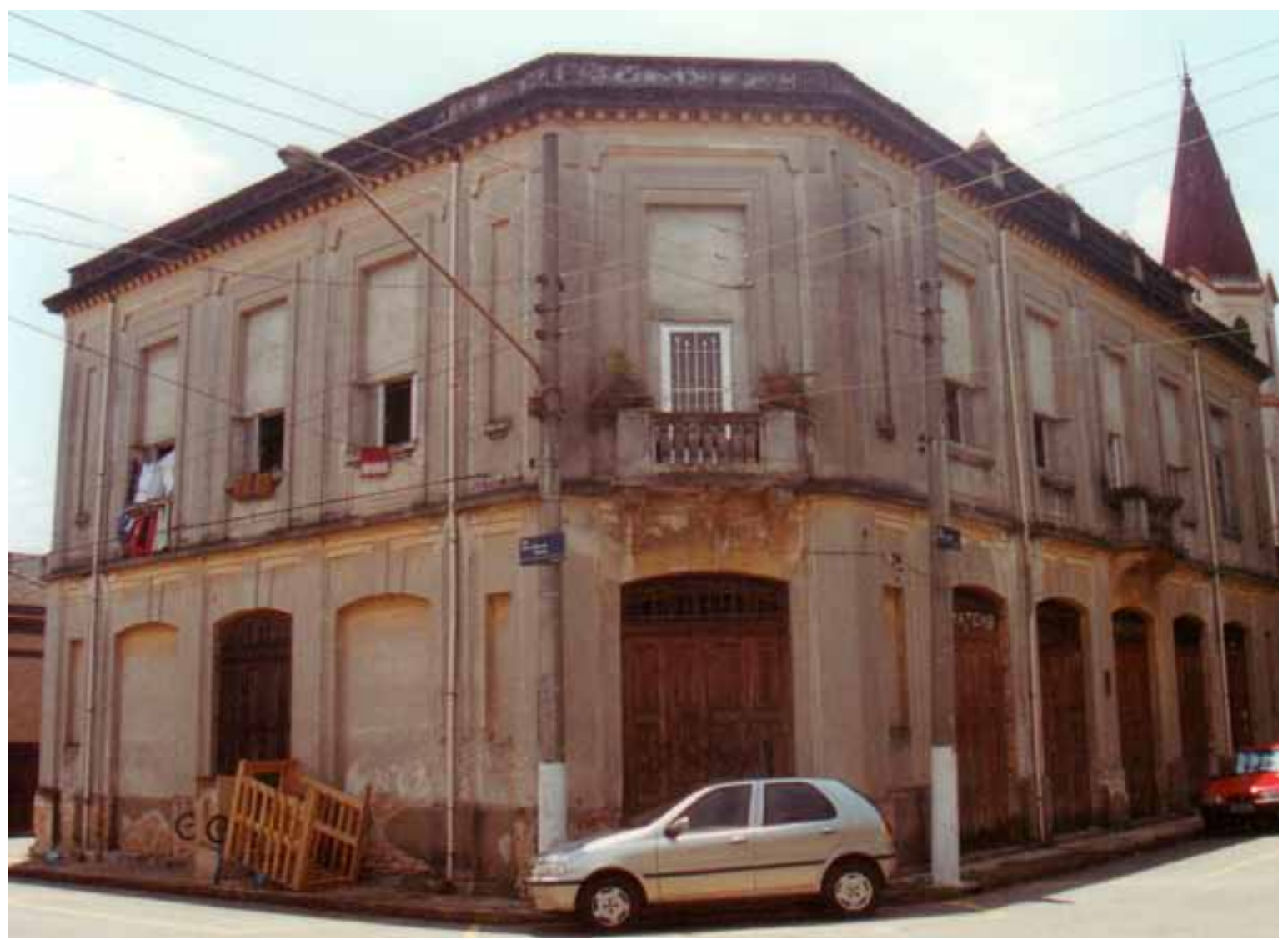

Figura 42 - Prédio do Armazém na Vila Maria Zélia, criada pela Companhia Nacional de Tecidos de Juta, em São Paulo (SP). Fotografia de Philip Gunn, 2001. 
38. Cf. Carla Milano Benclowicz (1989, p. 344).

39. Ver foto em Jack Reynolds (1985, p. 24).

40. Sobre a igreja de Worth, ver Banister Fletcher (1987, p. 359-361).

41. Sobre a igreja de Saint Mary, ver Roger Dixon e Stefan Muthesius (1995, p. 200-201).

42. Idem, p. 201. cornija, sob o frontão, remete a uma coluna cujo capitel estaria fixado à parede por um ornato em alvenaria que insinua a forma de um parafuso (Figura 43).

Na igreja, o uso econômico e simplificado de elementos do vocabulário românico, mas que expressam uma estética tipicamente industrial, solidariza-se com um movimento que buscou uma arquitetura simples e sincera, difundido, sobretudo, a partir da Inglaterra no século XIX. A igreja da Maria Zélia é exemplar de arquitetura historicista, marcada pela simplicidade da composição e do sistema de construção, características usuais, no período em questão, em igrejas de subúrbios, erguidas com recursos limitados. Apesar dessas características, o projeto revela domínio sobre o vocabulário estilístico, e cuidado na relação e na proporção entre seus elementos. Com sua torre, seus vãos em arco, óculo e pórtico, o prédio assinala claramente sua função e sua ascendência sobre as construções do entorno.

Carla Milano Benclowicz identifica semelhanças entre a igreja da Vila Maria Zélia e o prédio da Bolsa de Lã de Bradford, projetado na década de 1860 por Henry Francis Lockwood (181 1-1878) e Richard Mawson (18341904/38. A presença da torre é ponto em comum entre os dois prédios. $\bigcirc$ prédio da Bolsa, entretanto, diferencia-se por sua composição simétrica e pela profusa decoração com motivos diversos do vocabulário gótico. Por outro lado, a igreja metodista de Saltaire ${ }^{39}$ - próximo a Bradford - recupera elementos do vocabulário românico, que nela também surge muito simplificado, embora em forma muito diversa da assumida pela igreja da Vila Maria Zélia.

Na Maria Zélia, a igreja parece ter-se inspirado em templos românicos ingleses, como a igreja de Saint Nicholas, em Worth, no condado de Sussex, erguida em meados do século $\left.X\right|^{40} \mathrm{e}$, mais especialmente, em modelos do século XIX inspirados nesse estilo, como a igreja de Saint Wilfrid, em Hulme, construída em 1842 com projeto de Augustus Welby Pugin (1812-1852); e a igreja de Saint Mary, em Par, erguida em 1847, segundo projeto de George Edmund Street (1824-1881 ${ }^{41}$. Embora com dimensões menores, a da Maria Zélia tem em comum com a última os contrafortes, a volumetria da nave e, sobretudo, a forma da torre. A de Saint Mary é exemplo do movimento Ecclesiological inglês, cuja principal contribuição, para Dixon e Muthesius, foi amparar-se na simplicidade rural, resultando numa arquitetura modesta e sincera. Nela, os materiais baratos e simples surgem como são, em construções com beirais à vista, eliminando elementos como pináculos e parapeitos ${ }^{42}$. Seguindo as tendências do chamado ecletismo tipológico que se difundiu no século XIX, a igreja da Maria Zélia recorre a elementos da arquitetura românica, de cujo vocabulário histórico recupera arcos, contrafortes, torre com coruchéu octogonal, absides, frontões, pórtico e óculo, embora esse vocabulário, aí, surja reduzido a formas quase abstratas (Figura 44).

Nas moradias erguidas até 1919 (que constituem a maioria das casas da vila), as evidências de uma elaboração formal de inspiração industrial mostramse de forma mais clara e curiosa. As habitações, todas de um pavimento, estão, na maioria dos casos, dispostas em blocos de duas, três, quatro, seis ou oito casas. Havia moradias de seis diferentes tamanhos, com a área construída 


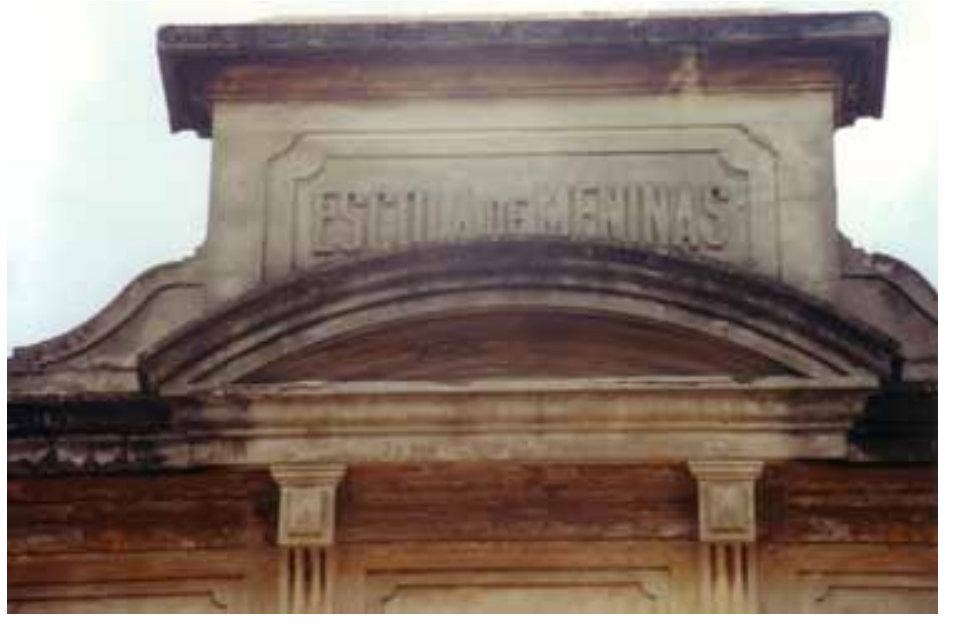

Figura 43 - Detalhe da fachada de escola na Vila Maria Zélia, em São Paulo (SP). Fotografia de Philip Gunn, 2001.

Figura 44 - Igreja da Vila Maria Zélia, em São Paulo (SP). Fotografia de Philip Gunn, 2001

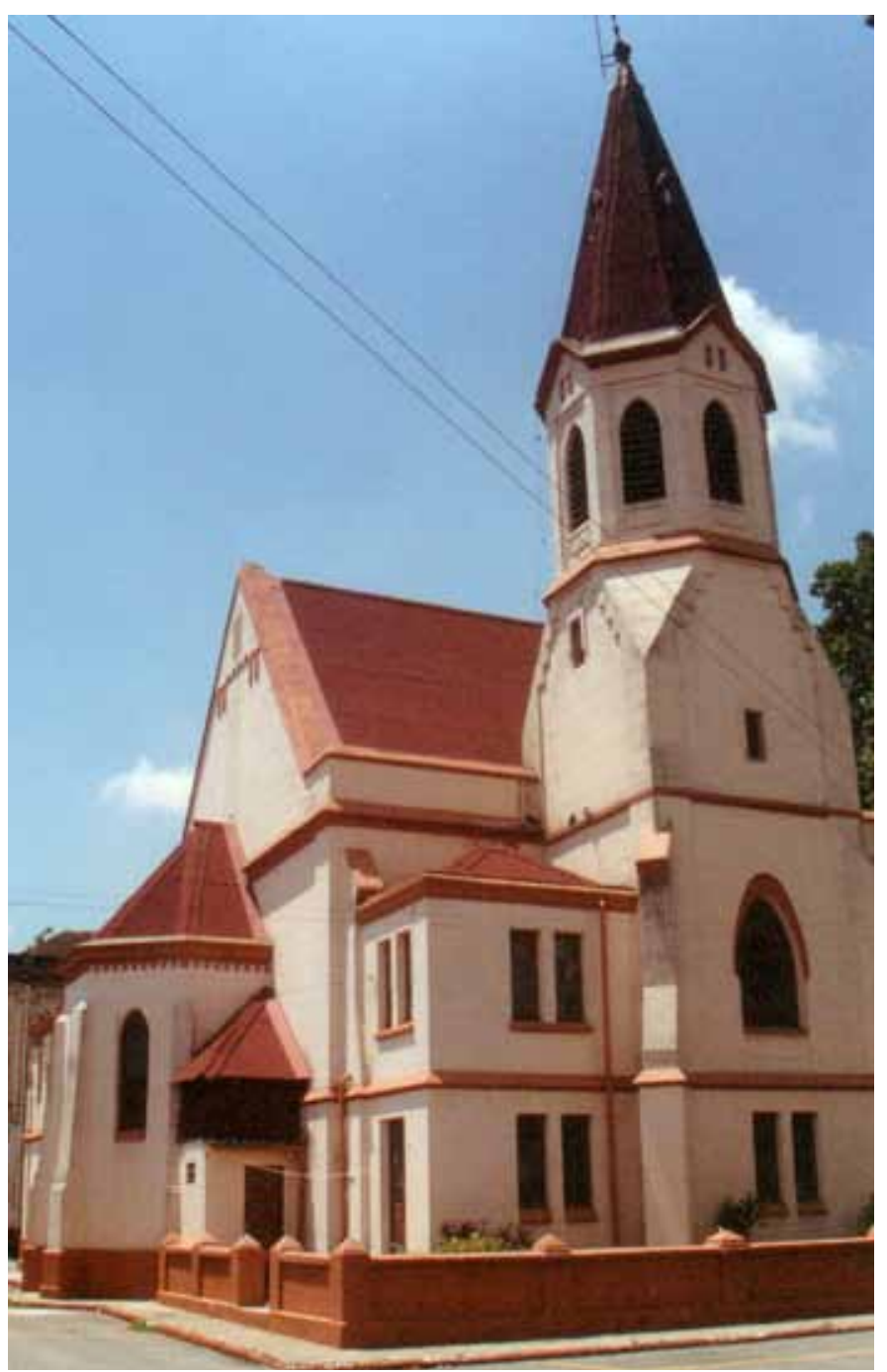


chegando, no máximo, a 72 metros quadrados. As casas menores tinham sala, quarto, cozinha e banheiro; e as maiores, sala, três quartos, cozinha e banheiro. Nos chalés havia, ainda, uma despensa. Todas dispunham de um pequeno quintal e, em algumas, havia também um jardim muito pequeno. Uma das tipologias implantava, de forma inovadora, a cozinha ao lado da sala, com janela abrindo para a fachada principal da casa. As casas maiores destinavamse a trabalhadores mais qualificados, com mais tempo de serviço na fábrica ou com famílias maiores. Para solteiros, havia alojamentos: prédio térreo, com 26 apartamentos, salas de estar e jantar, sala de costura, cozinha, sanitários, sala de banho e tanques.

Os blocos de casas que configuravam os quarteirões receberam um tratamento formal que integrava as pequenas casas em um elemento construtivo único, conferindo unidade ao bloco e uma certa monumentalidade ao conjunto. Os alojamentos para solteiros receberam tratamento formal semelhante.

A composição das fachadas dessas casas pode ser interpretada como um exercício de junção de elementos clássicos reelaborados com motivos ornamentais inspirados no mundo industrial. Nos blocos de casas, há um entablamento onde a cornija desenvolve desenhos geométricos, movimentando as fachadas e delimitando as quinas das quadras, enquanto uma arquitrave estreita delimita um friso onde elementos de decoração reproduzem formas simples. Em alguns momentos, a cornija eleva-se sobre as portas desenhando uma espécie de frontão (Figura 45).

No prédio dos alojamentos para solteiros, são criados frontões dessa natureza sobre portões em arco pleno, dotados de moldura com chave e gotas. Nesse prédio, a arquitrave é reduzida a uma faixa que, em um movimento em zig-zag, compõe, simultaneamente, a moldura das janelas (Figura 46).

Um aspecto curioso nas fachadas dessas moradias - tanto nas casas quanto no prédio dos alojamentos - é o uso de elementos decorativos remetendo ao mundo industrial. Nelas, sóbrios desenhos no reboco seguem formas geométricas que podem ser associadas a instrumentos e produtos da indústria moderna: quadriláteros sugerem chapas de metal; prismas insinuam a forma de parafusos e suas respectivas porcas; formas circulares sugerem manivelas fixadas por meio de parafusos; linhas paralelas em baixo-relevo junto a estas "manivelas" sugerem as correias que articulam as engrenagens. Em alguns momentos, esses "parafusos" e "manivelas" ocupam, nos pequenos frontões, a posição dos óculos, com lugar central na composição das fachadas (Figuras 47a-47c).

As molduras dos arcos dos alojamentos, ornamentadas com prismas que sugerem grandes parafusos dotados de porcas, parecem tratadas como chapas de metal parafusadas. As chaves dos arcos são representadas por formas que insinuam "parafusos" maiores e suas respectivas porcas, assumindo disposição e formato diferenciados daqueles dos outros quatro "parafusos" que "prendem" a moldura (Figura 48).

A residência do gerente teve seu projeto encaminhado à Prefeitura (junto com o projeto do prédio da administração da fábrica) em 1917 para obtenção de alvará para construção. Era uma ampla casa de dois andares sobre 


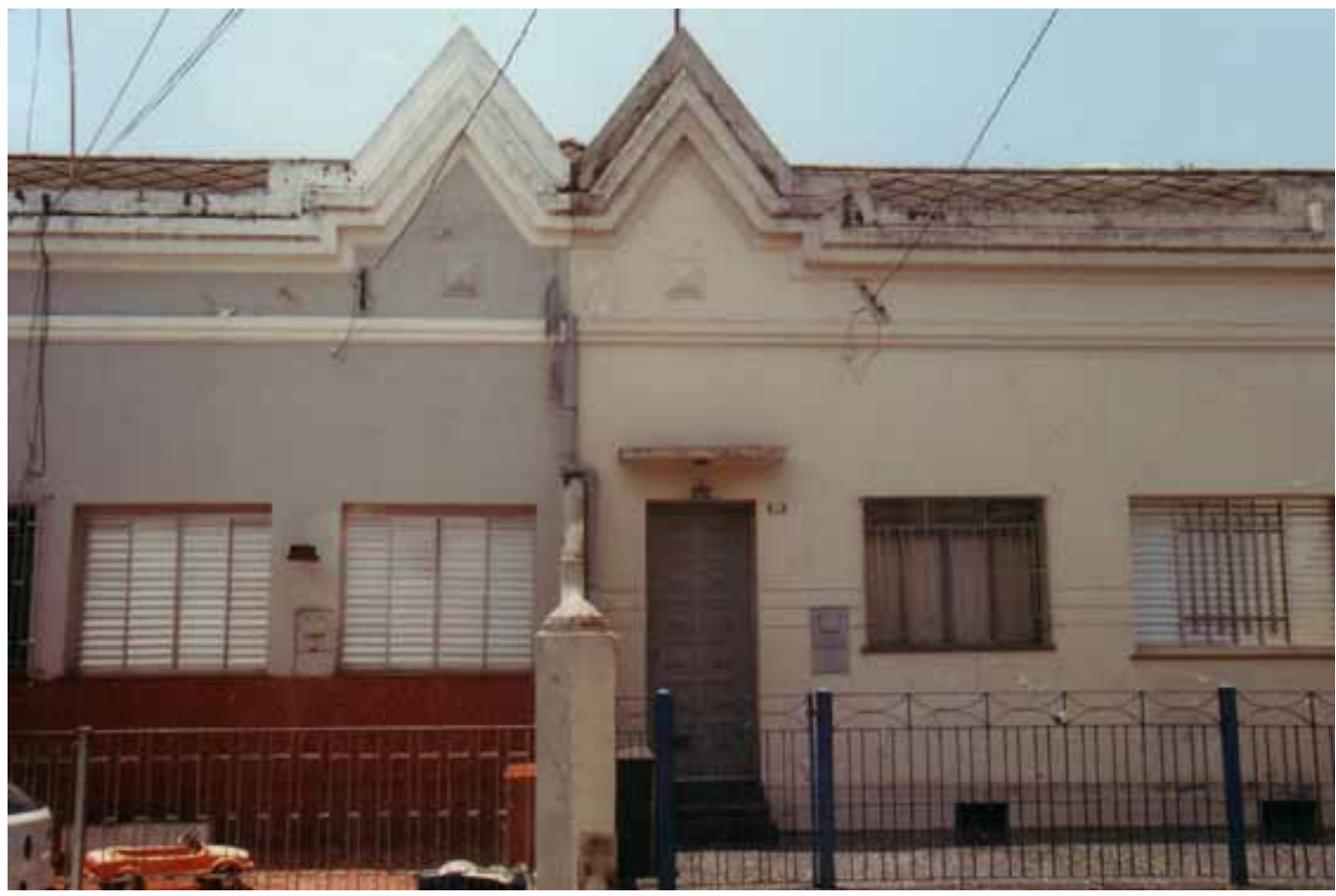

Figura 45 - Casas na Vila Maria Zélia, em São Paulo (SP). Fotografia de Philip Gunn, 2001.

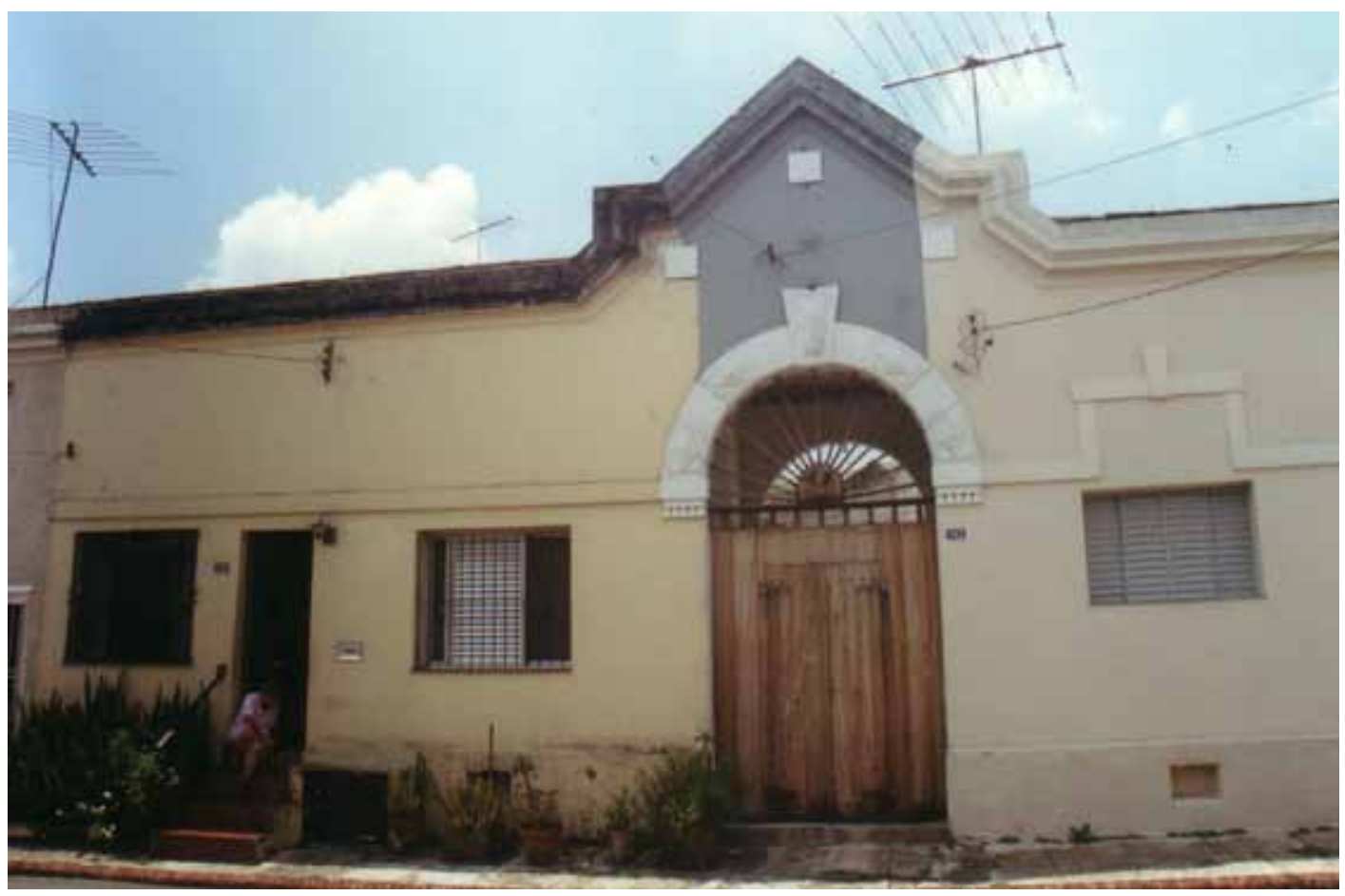

Figura 46 - Alojamento para Solteiros na Vila Maria Zélia, em São Paulo (SP). Fotografia de Philip Gunn, 2001. 
Figura 47a - Detalhe da composição de fachada de casa na Vila Maria Zélia, em São Paulo (SP). Fotografia de Philip Gunn, 2001.

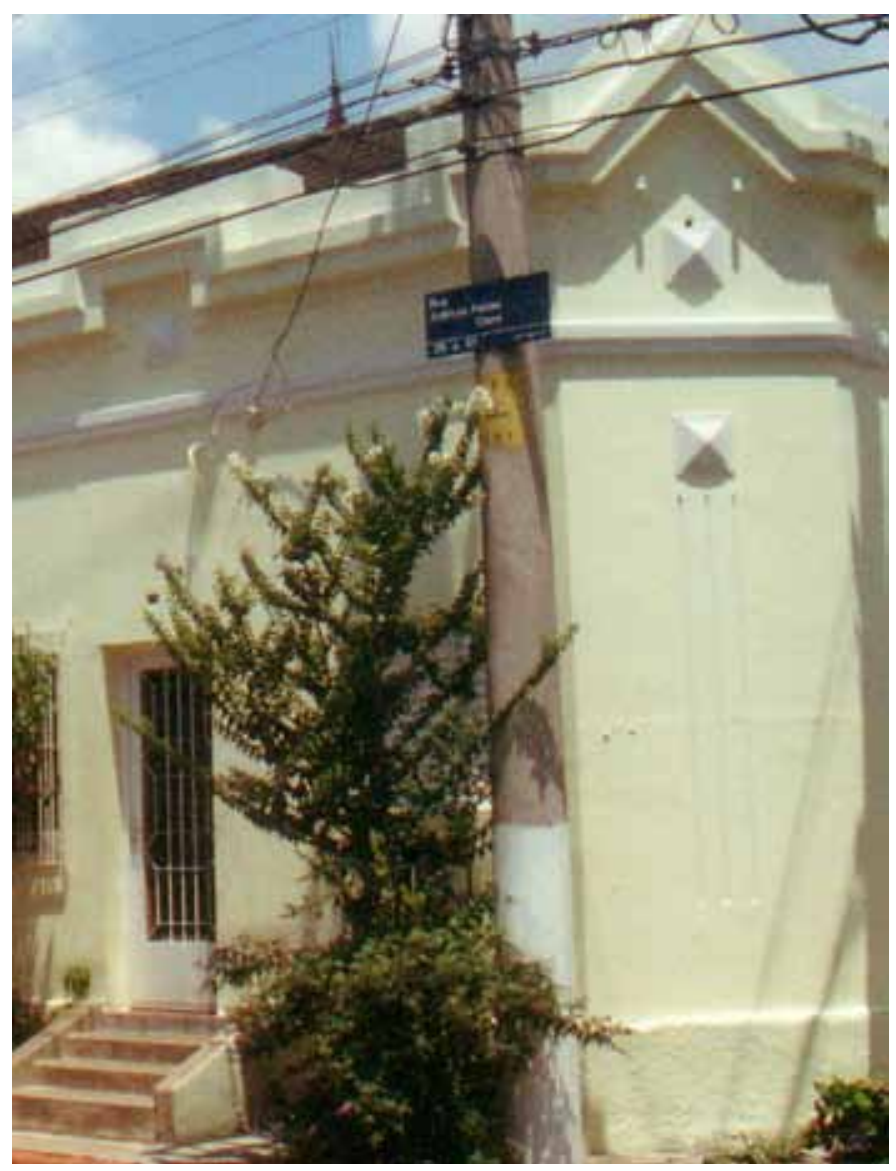

Figura 47b - Detalhe da composição de fachada de casa na Vila Maria Zélia, em São Paulo (SP). Fotografia de Philip Gunn, 2001.

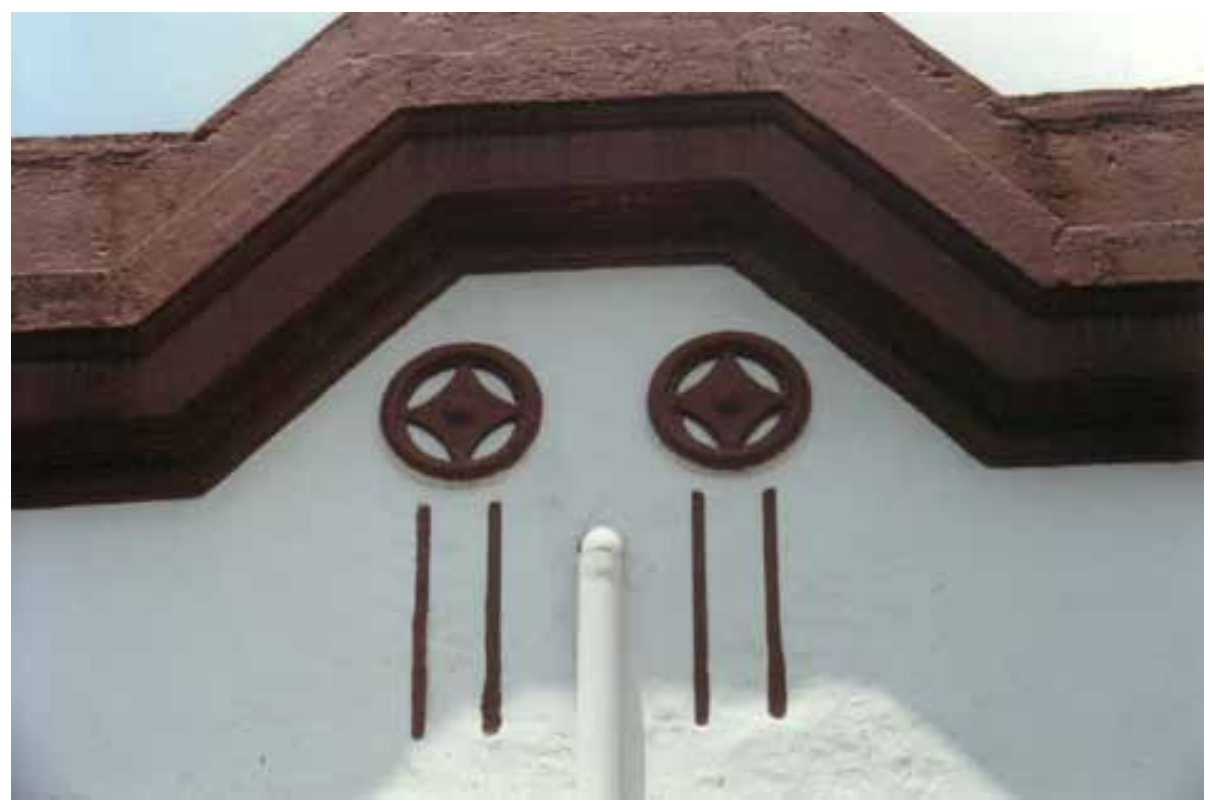




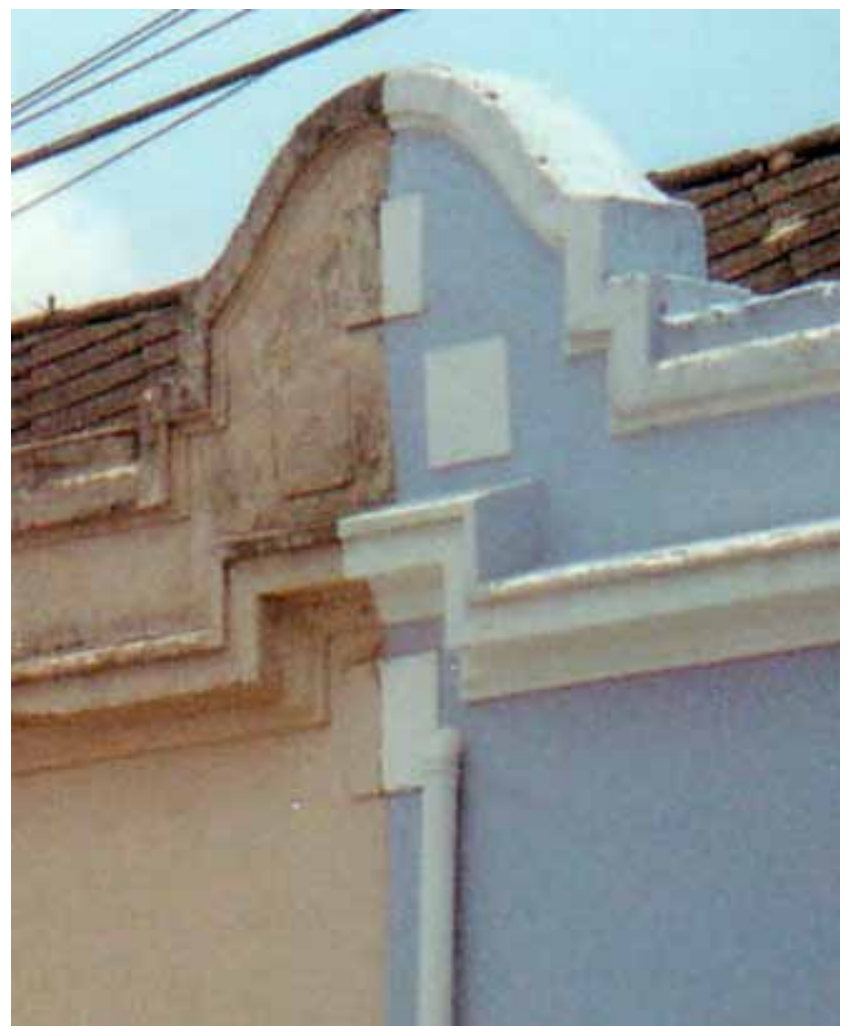

Figura 47c - Detalhe da composição de fachada de casa na Vila Maria Zélia, em São Paulo (SP). Fotografia de Philip Gunn, 2001.

Figura 48 - Detalhes da composição das fachadas dos alojamentos na Vila Maria Zélia, em São Paulo (SP). Fotografia de Philip Gunn, 2001.

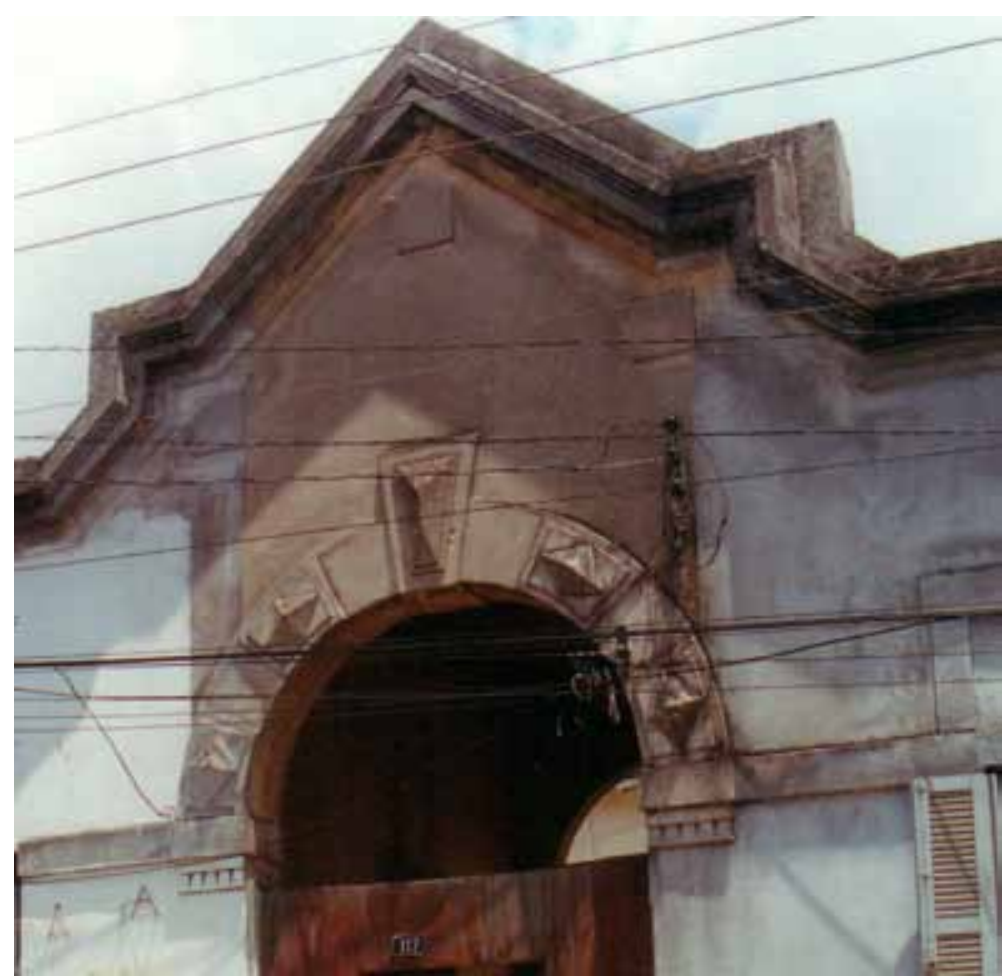

Annals of Museu Paulista. v. 19. n.1. Jan.-June 2011. 
43. Cf. Carla Milano Benclowicz (1989, p. 467-469).

44. Idem, p. 471. porão não habitável, dotada de recuos laterais, que se comunicava diretamente com a fábrica através do quintal ${ }^{43}$. Seu projeto concilia detalhes, como a forma da platibanda, presentes também nas casas da vila operária, mas com alguns componentes e uma elaboração formal - balaustrada, pilastras, vãos em arco pleno ou abatido, ornamentos e porão - que o aproximam dos prédios de uso coletivo e do prédio da administração da fábrica.

Este último é uma construção de dois andares, erguida sobre porão não habitável e tendo o terceiro pavimento ocupado por reservatório de água. Sem se afastar muito da linguagem empregada nos prédios que abrigam o armazém e o restaurante, tem ornamentação mais profusa e composição mais monumental. No seu projeto, a curiosidade refere-se à solução de telhado empregada para cobrir o reservatório de água, que, entretanto, foi alterada na construção. No Memorial à Prefeitura, que acompanhou em 1917 o pedido de alvará para construção, a solução original da coberta - com estrutura em ferro, telhas Eternit e deixando um vão entre ela e o reservatório - foi assim justificada: "Independentemente do ponto de vista esthetico, é destinada a permitir a permanente ventilação das águas"44. Os prédios destinados à produção são galpões uniformes, de dois pavimentos, com fachadas dotadas de pilastras, platibanda, cornija e amplas janelas com caixilharia de vidro e guarnecidas com moldura. São feitos de alvenaria de tijolos, com estrutura de ferro e têm abertura zenital.

Na Maria Zélia, além das moradias já citadas, foram erguidas provavelmente após 1919 - casas seguindo duas outras tipologias. Uma delas compõe-se de casas geminadas em blocos, com porta e janela na fachada. Dotadas de platibanda, cornija, molduras em torno dos vãos e com rusticação estilizada da alvenaria obtida por meio de linhas paralelas em baixo-relevo, a composição dessas casas aproxima-se da empregada nos prédios das escolas, do armazém e do restaurante. Outra tipologia presente diz respeito a um grupo de pequenos chalés, dotados de alpendre, sala, dois quartos, cozinha e sanitário. Suas fachadas, destituídas de ornatos, deslocam a busca de efeitos estéticos para a composição volumétrica, obtida pela junção de um pórtico ao corpo principal da casa.

\section{A abolição de ornatos}

Em vilas operárias e núcleos fabris erguidos no Brasil desde a última década do século XIX, na adoção de uma linguagem despojada, caracterizada pela abolição de ornatos - praticada em moradias e até em prédios usualmente mais ornamentais como igrejas -, também se fazem sentir impactos do mundo industrial e da arquitetura por ele gerada.

Entre as construções com exterior em tijolo aparente já citadas, foram mencionados exemplos - como os chalés em Galópolis e algumas tipologias de casas e sobrados em Votorantim - em que se procedeu a uma total abolição de ornatos. Outro exemplo notável de moradia em tijolo aparente com eliminação total de ornatos é a Vila Boyes, erguida na cidade de São Paulo entre 1919 e 
1924 pela Fábrica São Simeão. Compunha-se de 97 casas, destinadas, sobretudo, a operários especializados. Posteriormente, funcionaram no local uma cooperativa de consumo e um posto médico, também criados pela fábrica. Nessa Vila, todas as casas são iguais, exceto três delas, maiores, destinadas a gerentes, cujos projetos são diferenciados (duas adotam a forma de chalés), mas preservam o compromisso com o despojamento de ornatos, testemunhado inclusive pelo desenho simples em vitrais, guarda-corpos e portão em madeira. As casas para operários da Vila Boyes são sobrados dispostos em renque, sem recuo frontal, dispondo apenas de um pequeno quintal. A simplicidade das fachadas encontra correspondência na organização dos espaços internos. Com cerca de 50 metros quadrados, tinham sala, dois quartos, cozinha e sanitário. Tais casas revelam-se inovadoras, deduzidas a partir de necessidades de higiene, conforto e de economia. Têm janelas em todos os cômodos, sanitário incorporado ao corpo da casa - solução rara na época em moradias para trabalhadores - e janela da cozinha na fachada principal - outra solução rara. A repetição da tipologia permitiu a padronização de componentes, enquanto o projeto (no esquema twoup, two-down) possibilitou alinhar as paredes do térreo e as do primeiro pavimento. A economia também preside a composição das fachadas de tijolo aparente desprovidas de detalhes ornamentais, dotadas de janelas estreitas dispostas de forma assimétrica, e tendo aparentes as calhas e a tubulação de águas pluviais. As telhas - do tipo Marselha - também são visíveis, prolongando-se em beirais. Sua arquitetura reflete um momento em que a composição se simplifica, o que testemunha a difusão de uma estética fabril onde princípios utilitaristas conduzem à crescente redução das fachadas a seus componentes essenciais, eliminando resquícios de composições clássicas ou de cunho beaux-arts, tais como simetria e ornatos (Figura 49).

Já na década de 1890, essa tendência à abolição de ornatos em construções de alvenaria de tijolos com exterior revestido de reboco pode ser identificada. Um exemplo relevante nesse sentido é a Vila Boa Viagem, construída em Salvador (BA), entre 1891 e 1895, pela fábrica têxtil Empório Industrial do Norte, cujo fundador foi Luiz Tarquínio. Consta que a construção da vila foi realizada pela firma inglesa Felher Jueker, sob a direção dos engenheiros August Wellemmann e Augusto Lacerda ${ }^{45}$. A vila compunha-se de 258 sobrados dispostos em longos blocos e seguindo três tipos de plantas. A maioria das habitações 243 unidades - tinha 71,96 m², incluindo duas salas, copa, cozinha e banheiro no térreo, e dois quartos no pavimento superior. Havia 13 casas maiores, com 165,26 $\mathrm{m}^{2}$, que contavam com três salas, copa, cozinha e banheiro no térreo, e cinco quartos no pavimento superior. Um último tipo de habitação era composto por quatro apartamentos: os situados no térreo, com duas salas, dois quartos, cozinha e banheiro; os do pavimento superior, com duas salas, três quartos, cozinha e banheiro. Algumas casas tinham, na frente, um jardim muito pequeno (na realidade um canteiro estreito); outras, um jardim lateral. Não apresentavam nenhum elemento decorativo nas fachadas, exceto uma pilastra que demarcava os limites de cada habitação (Figura 50). 
Figura 49 - Casas de operários e técnicos especializados na Vila Boyes, construída entre 1919 e 1924, pela Fábrica São Simeão, São Paulo (SP). Fotografia de Philip Gunn, 2001.

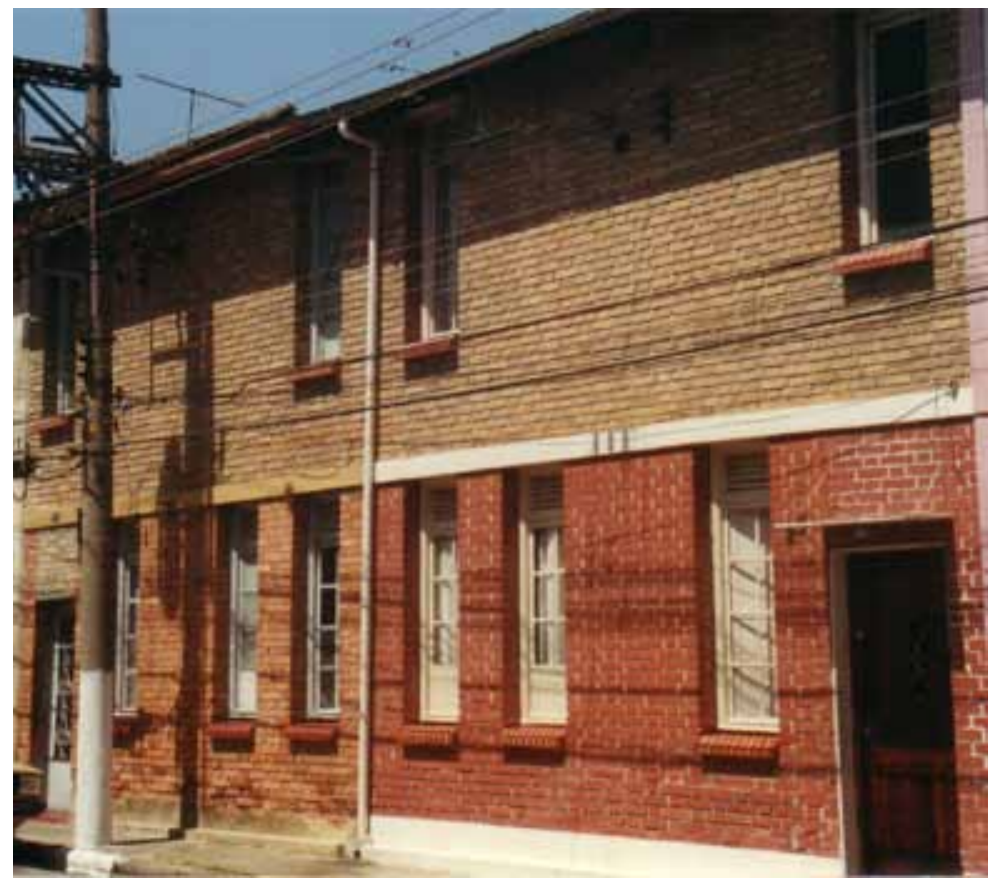

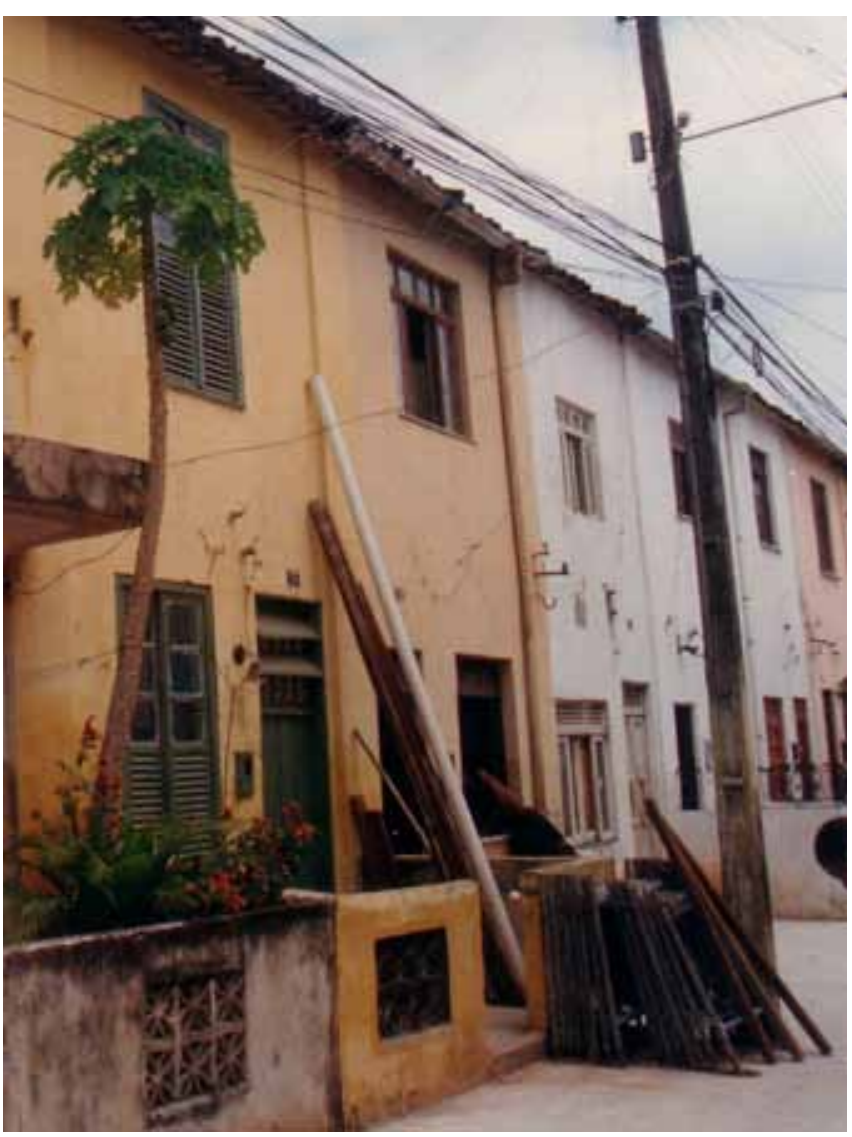

Figura 50 - Casas na Vila Boa Viagem, em Salvador (BA). Fotografia de Philip Gunn, 1997. 
Semelhante às moradias da Vila Boa Viagem são os sobrados construídos pela Fábrica de Tecidos Marzagão, inaugurada em torno de 1880, em área rural do município de Sabará (MG). No caso, por se tratar de localidade com terra abundante e de baixo valor, ter sido criada uma moradia mais compacta revela claramente uma opção por esse modelo de habitação operária (Figura 51 ).

O padrão de moradia aplicado por essas duas fábricas - assim como o dos sobrados de tijolo aparente de Votorantim e das vilas Boyes e Cerealina em São Paulo, já tratados - foi nitidamente influenciado pelo modelo das tenementhouses - padrão de moradia compacta, padronizada e econômica que se estendeu pelos subúrbios operários da Inglaterra no século XIX. Trata-se de mais um aspecto da influência dos modelos britânicos de fábricas sobre os empreendimentos nacionais.

Entretanto, nas vilas operárias e núcleos fabris do Brasil, o padrão que se generalizou desde o final do século XIX foi outro: são casas térreas, dispostas

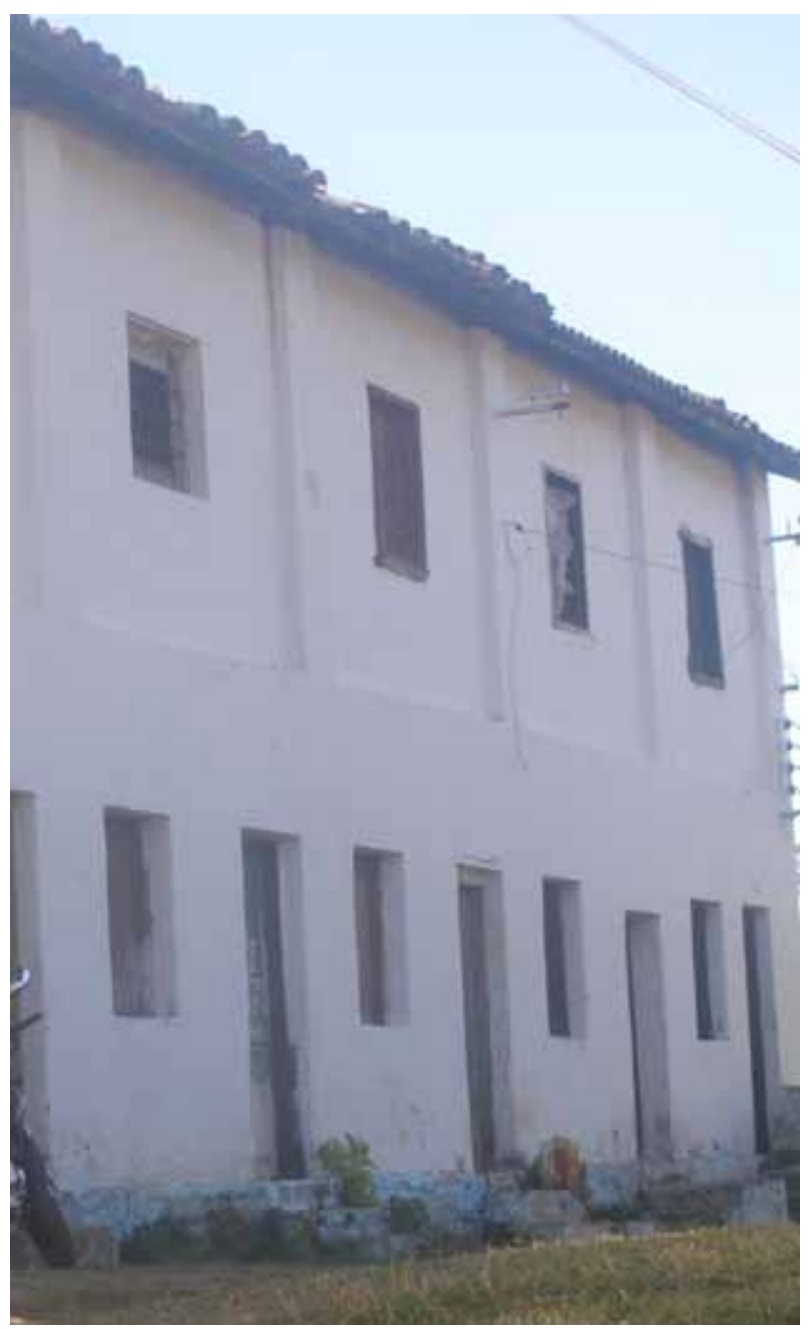

Figura 51 - Casas em Marzagão (MG) Fotografia de Vanda Quecini, 2007. 
46. Núcleo fabril criado pela Fábrica de Fiação e Tecidos Pau Grande, em Magé (RJ), a partir de 1878 .

47. Tais exemplos podem ser encontrados: em Caieiras (SP), no núcleo fabril fundado pela Companhia Melhoramentos S.A, cuja construção teve início na década de 1880 e estendeu-se até a década de 1940; no núcleo fabril da Companhia de Fiação Cometa (Meio da Serra), erguido a partir da década de 1890 em área rural próxima à cidade de Petrópolis (RJ); e no núcleo fabril da Fábrica de Papel e de Papelão Pedras Brancas, fundada em 1898, em Bom Retiro, uma localidade rural no município de Guaíba (RS). Tal padrão também foi construído, já no século XX, pela Fábrica do Cedro, em Taboleiro Grande, depois Caetanópolis (MG); e na Fazenda Coruputuba, um núcleo fabril criado pela Companhia Agrícola e Industrial Cícero Prado, em Pindamonhangaba (SP), entre as décadas de 1920 e 1950. Também são exemplos desse padrão algumas das vilas da Siderúrgica Belgo-Mineira em Sabará (erguidas da década de 1920 à de 1950), assim como casas da Fábrica de Tecidos Cachoeira, ambas em Minas Gerais. Esta tipologia também está presente: na Vila Iolanda e na Vila do Pombal, ambas criadas por fábricas têxteis no Recife; na Vila Poty, núcleo fabril criado pela Fábrica de Cimento Portland Poty, em Pernambuco e na Vila Santa Helena núcleo fabril da Fábrica Votoran, no estado de São Paulo, ambas integrantes do Grupo Votorantim; em Saramenha, núcleo fabril criado pela Alcan em Minas Gerais; em Alumínio, núcleo fabril criado pela Companhia Brasileira de Alumínio, do Grupo Votorantim, em São Paulo; bem como as vilas operárias da Fábrica Maria Amália em Curvelo (MG), da Renascença em Belo Horizonte (MG), da Siderúrgica Barra Mansa, da Sifco em Jundiaí (SP) e da isoladas, geminadas ou em blocos; destituídas de ornatos; construídas em alvenaria de tijolos; cobertas com telhas cerâmicas do tipo francesa; dotadas de portas e janelas com vidros e/ou venezianas; e com programa composto de uma ou duas salas, dois ou três quartos, cozinha, sanitário e quintal. No seu absoluto despojamento de ornatos ou de qualquer pretensão de ordem formal, essa tipologia habitacional não é identificada com qualquer estilo ou movimento arquitetônico. É um padrão básico, que se fixou em escala nacional como decorrência de demandas de higiene, conforto e economia. Embora simples, tal modelo de habitação trouxe para a casa do trabalhador brasileiro inovações importantes em termos de materiais e de agenciamento dos espaços. E rompeu com os modelos de habitação operária anteriores, ao prover ambientes claros e dotados do conforto da infraestrutura e das instalações sanitárias modernas.

Eventualmente, esse modelo básico surgiu com três pequenas variações: introdução de pequeno pórtico ou alpendre na fachada principal; introdução de terraço abrindo para essa fachada; e substituição da alvenaria de tijolos por madeira.

Assim, em alguns casos, através do avanço do beiral sobre a porta da frente criava-se um pórtico, pequeno terraço ou alpendre estreito. Em alguns raros casos, tal pórtico foi obtido por meio de uma pequena laje plana. Em Pau Grande ${ }^{46}$, tal pórtico foi sublinhado por um guarda-corpo, que delimitava e protegia a entrada da habitação, podendo ter um destaque ainda mais acentuado quando, em função de desnível do terreno, ele se prolongava em escadaria, cujas ênfase e forma denunciam heranças barrocas. A segunda pequena variação na tipologia, através da criação de um terraço implantado no corpo central da moradia, foi mais comum nas décadas de 1930 e 1940, quando, eventualmente, tal terraço podia ser dotado de abertura em T. A terceira variação na tipologia, referente à substituição da alvenaria de tijolos por madeira, esteve, nesse período, restrita aos estados da região Sul.

Algumas das primeiras casas erguidas pela Belgo-Mineira, em Sabará (MG), podem ser vistas como um momento de transição entre esse padrão - do qual recuperam a disposição geminada, o vidro na bandeira de portas e janelas, e o pequeno pórtico - e um padrão anterior, ainda fortemente atrelado à arquitetura do período colonial - do qual adotam a telha canal, e as portas e janelas de tábuas de madeira. (Figura 52)

Esse padrão - que se generalizou no Brasil desde final do século XIX - embora simples, traz para a casa do trabalhador inovações importantes em termos de materiais e de agenciamento dos espaços, solidárias com preceitos higienistas e requisitos de conforto. Exemplos dessa tipologia, que se multiplicou no país ${ }^{47}$, são retratados nas Figuras 53-62.

A tendência ao despojamento também se faz presente nos equipamentos de uso coletivo. $\bigcirc$ alojamento para solteiros erguido em Camaragibe (PE), no início do século XX, é um exemplo de simplificação e racionalização de projeto. Trata-se de uma construção sóbria, erguida em alvenaria de tijolos, onde a racionalidade construtiva se evidencia na absoluta ausência de ornatos, no alinhamento das paredes do térreo com as do primeiro pavimento, e na estrutura 


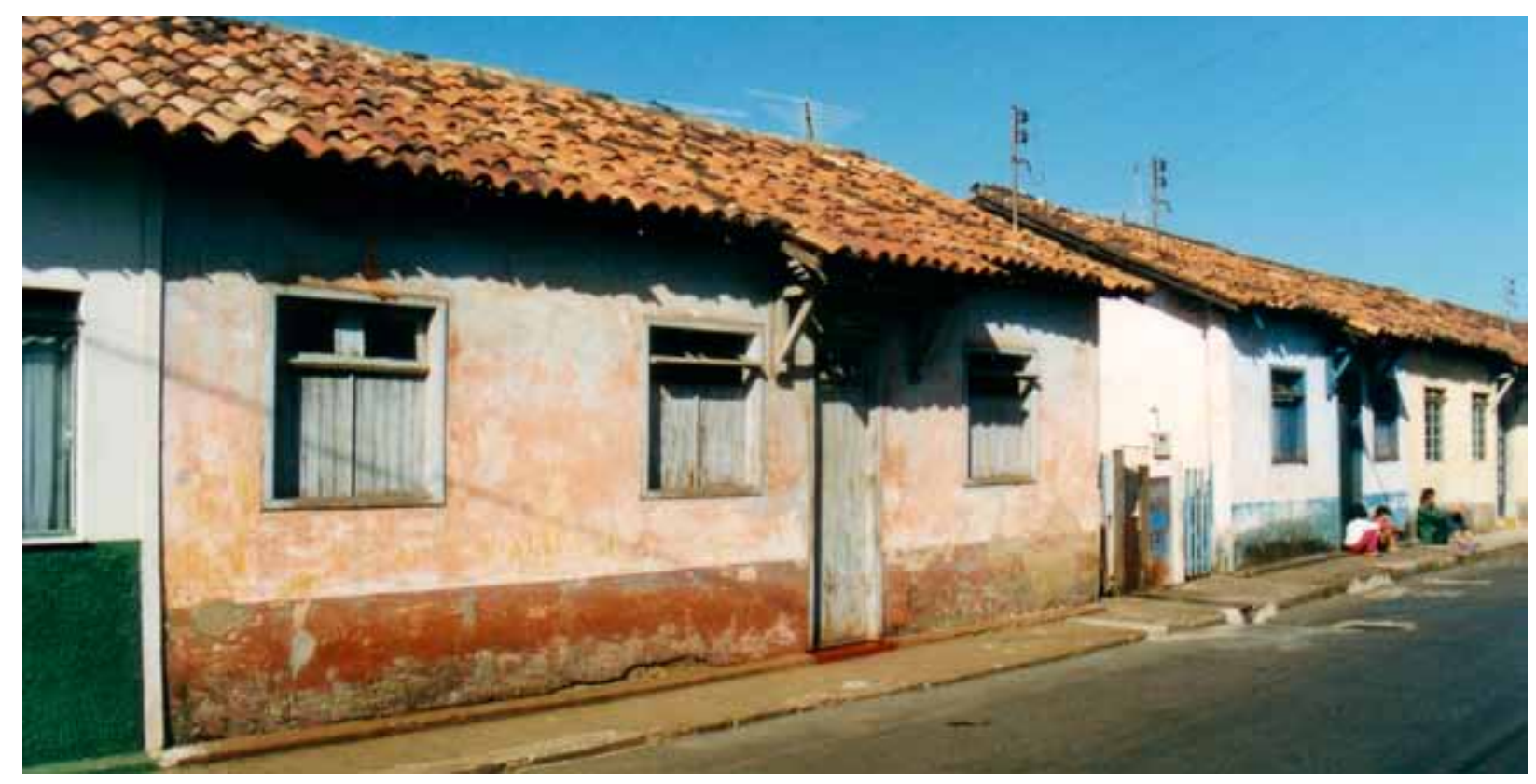

Figura 52 - Casas na vila operária da Siderúrgica Belgo-Mineira, em Sabará (MG). Fotografia de Philip Gunn, 1998.

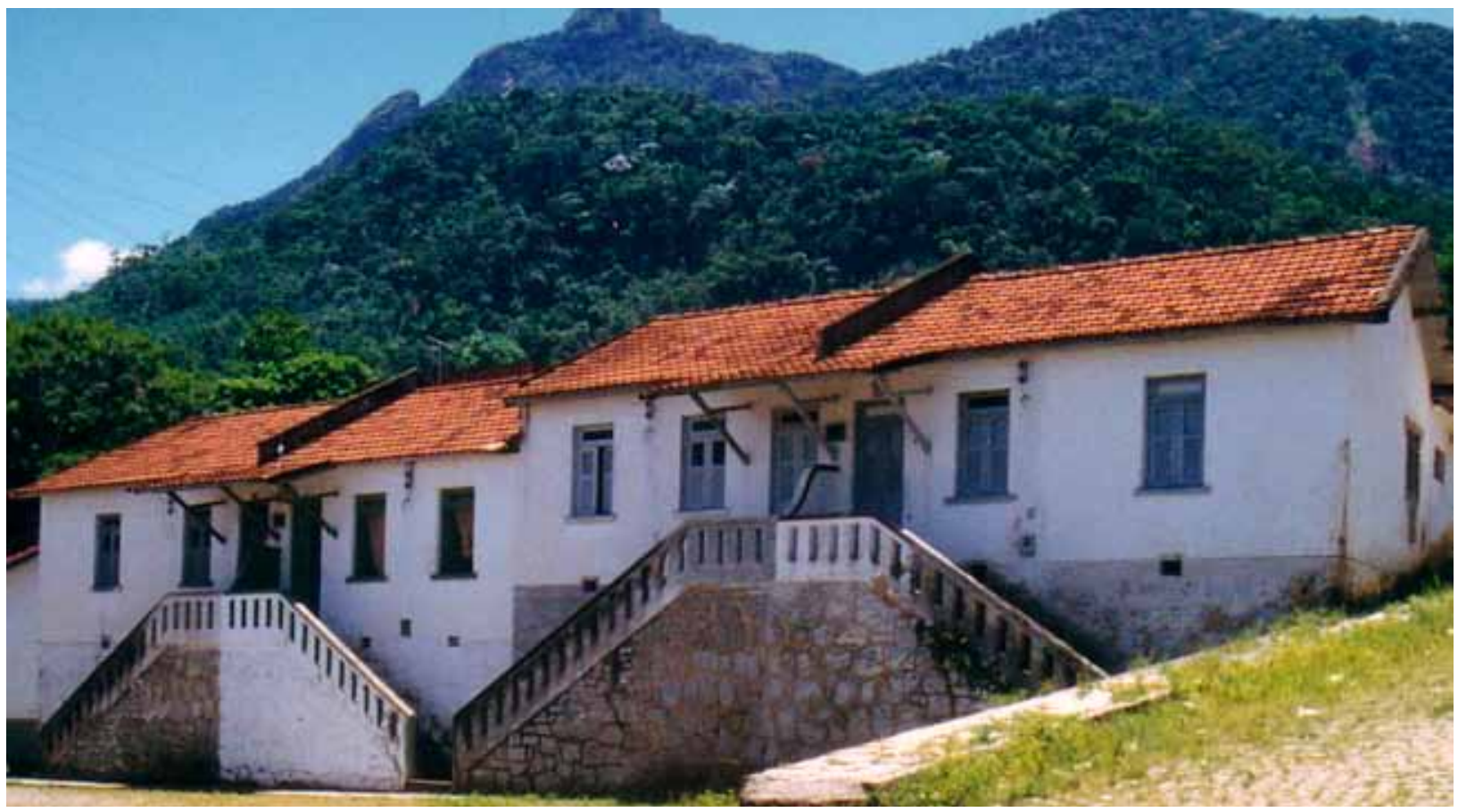

Figura 53 - Habitações em Pau Grande, Magé (RJ). Fotografia de Philip Gunn, 1998 - 
Itabirito Industrial em Itabirito (MG). Em construções de madeira ou de alvenaria de tijolos, a tipologia surge no Rio Grande do Sul, em núcleos habitacionais criados por empresas de mineração, como: Butiá, da Companhia Carbonífera Rio-Grandense, construído entre 1917 e a década de 1950; Arroio dos Ratos, da Companhia Estrada de Ferro e Minas São Jerônimo, construído entre o final do século XIX e a década de 1950; e Vila da Copelmi, em Charqueadas, construída a partir do final da década de 1940.

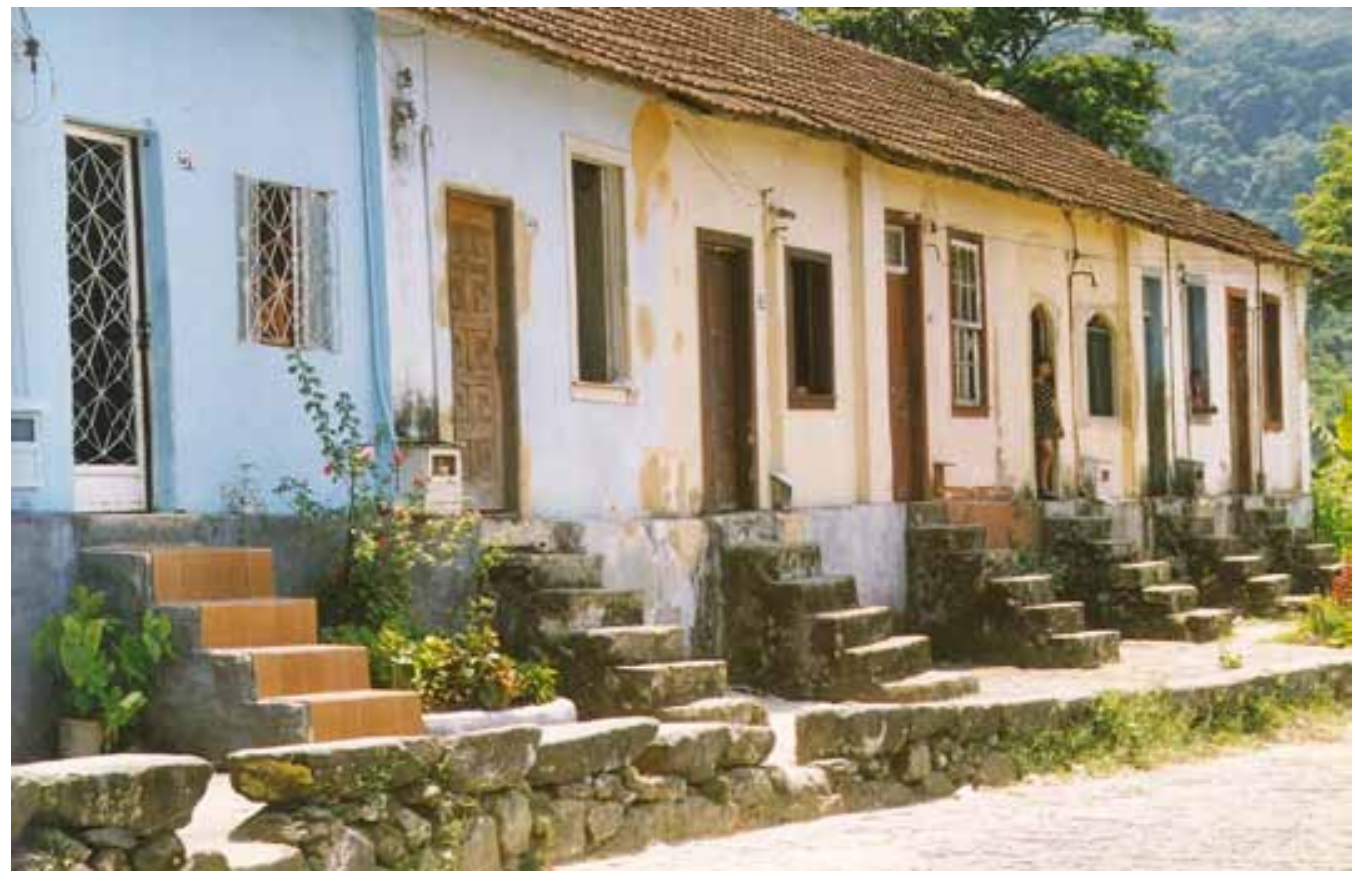

Figura 54 - Casas no núcleo fabril da Companhia de Fiação Cometa (Meio da Serra), Petrópolis (RJ). Fotografia de Philip Gunn, 1998.

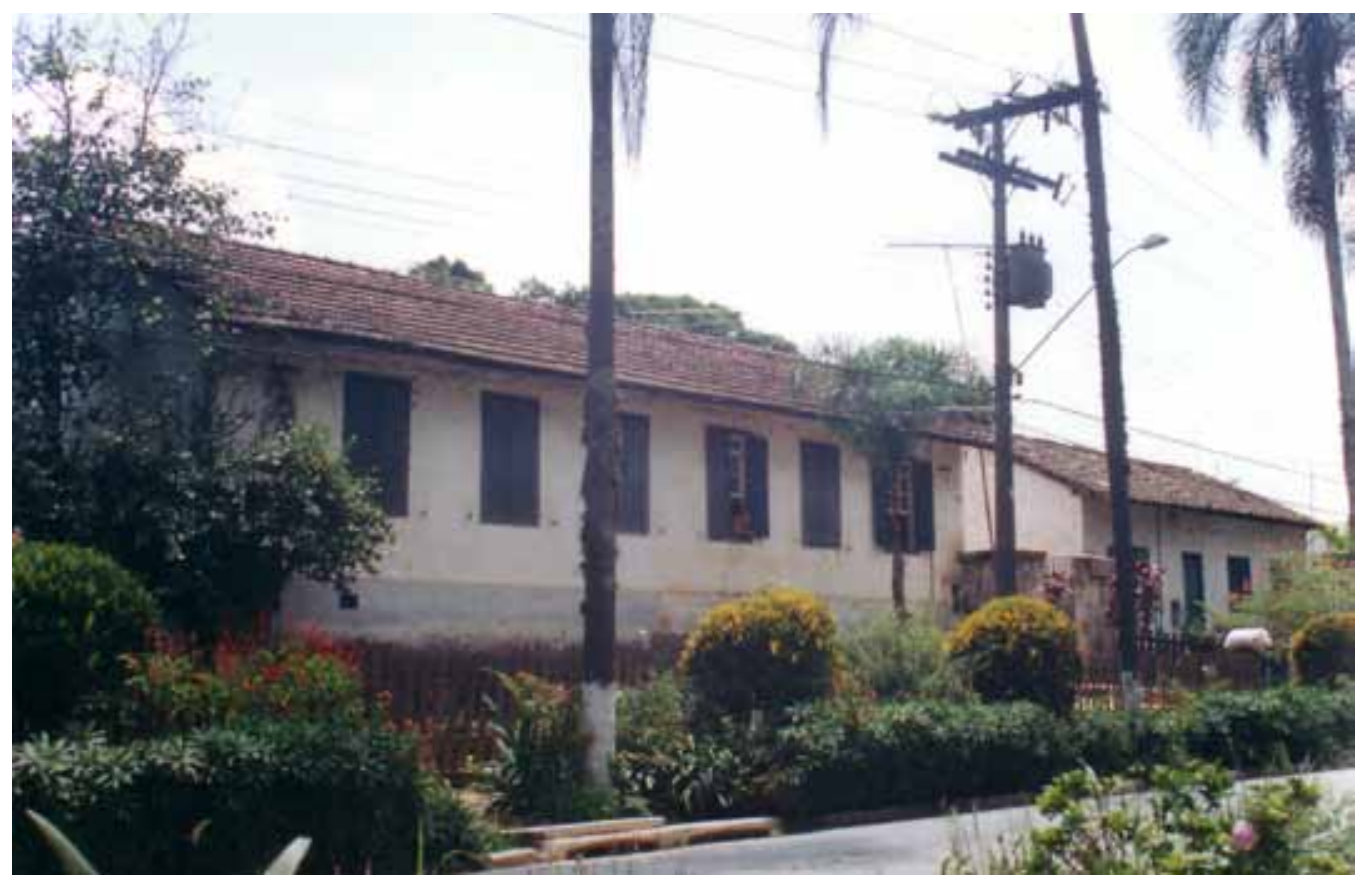

Figura 55 - Casas em Caieiras (SP). Fotografia de Philip Gunn, 2002. 


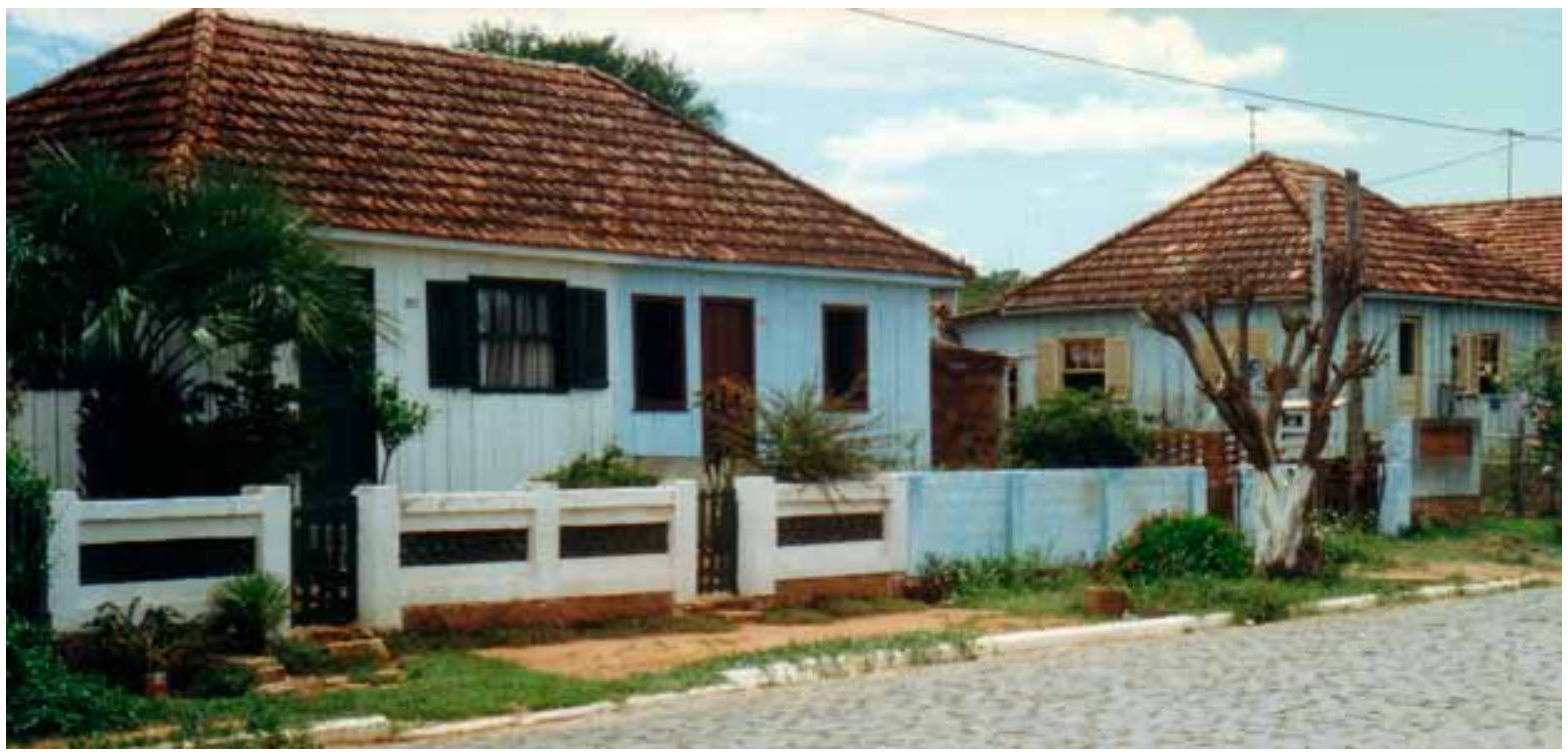

Figura 56 - Casas em Arroio dos Ratos (RS). Fotografia de Philip Gunn, 1997.

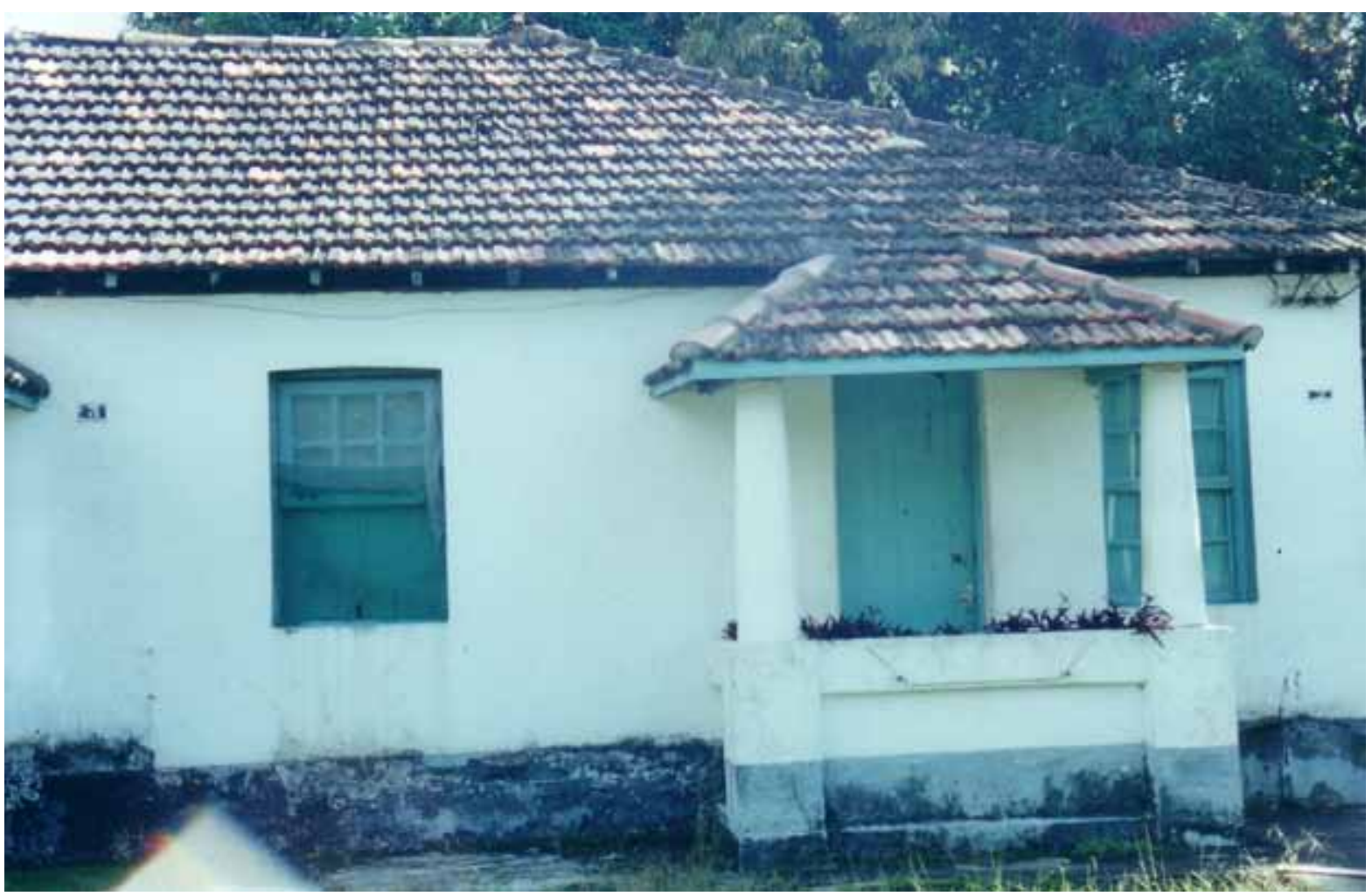

Figura 57 - Moradia na Fazenda Coruputuba, núcleo fabril criado Companhia Agrícola e Industrial Cícero Prado em Pindamonhangaba (SP). Fotografia de Philip Gunn, 2002. 


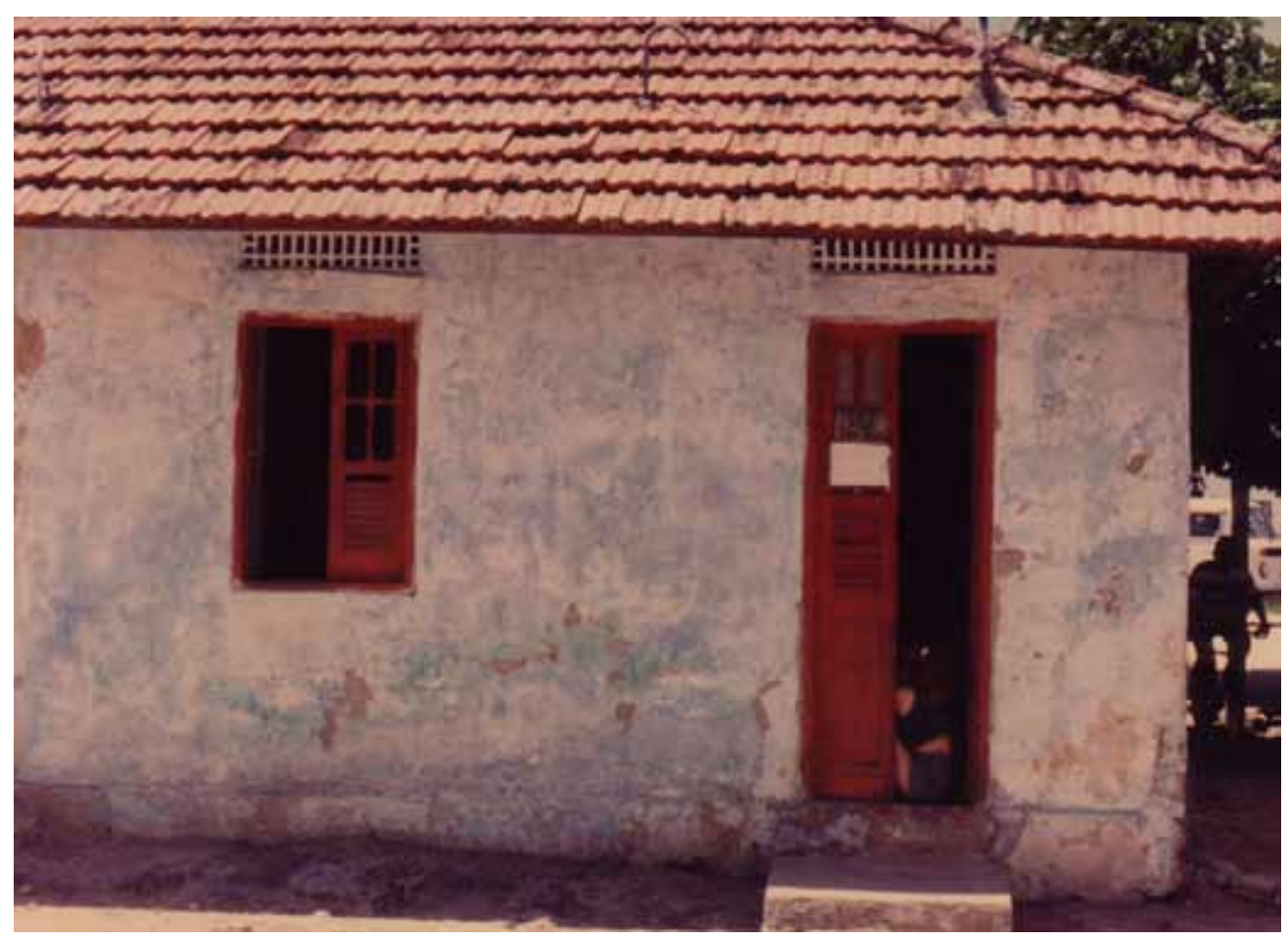

Figura 58 - Vila lolanda, no Recife (PE) Fotografia de Philip Gunn, 1996.

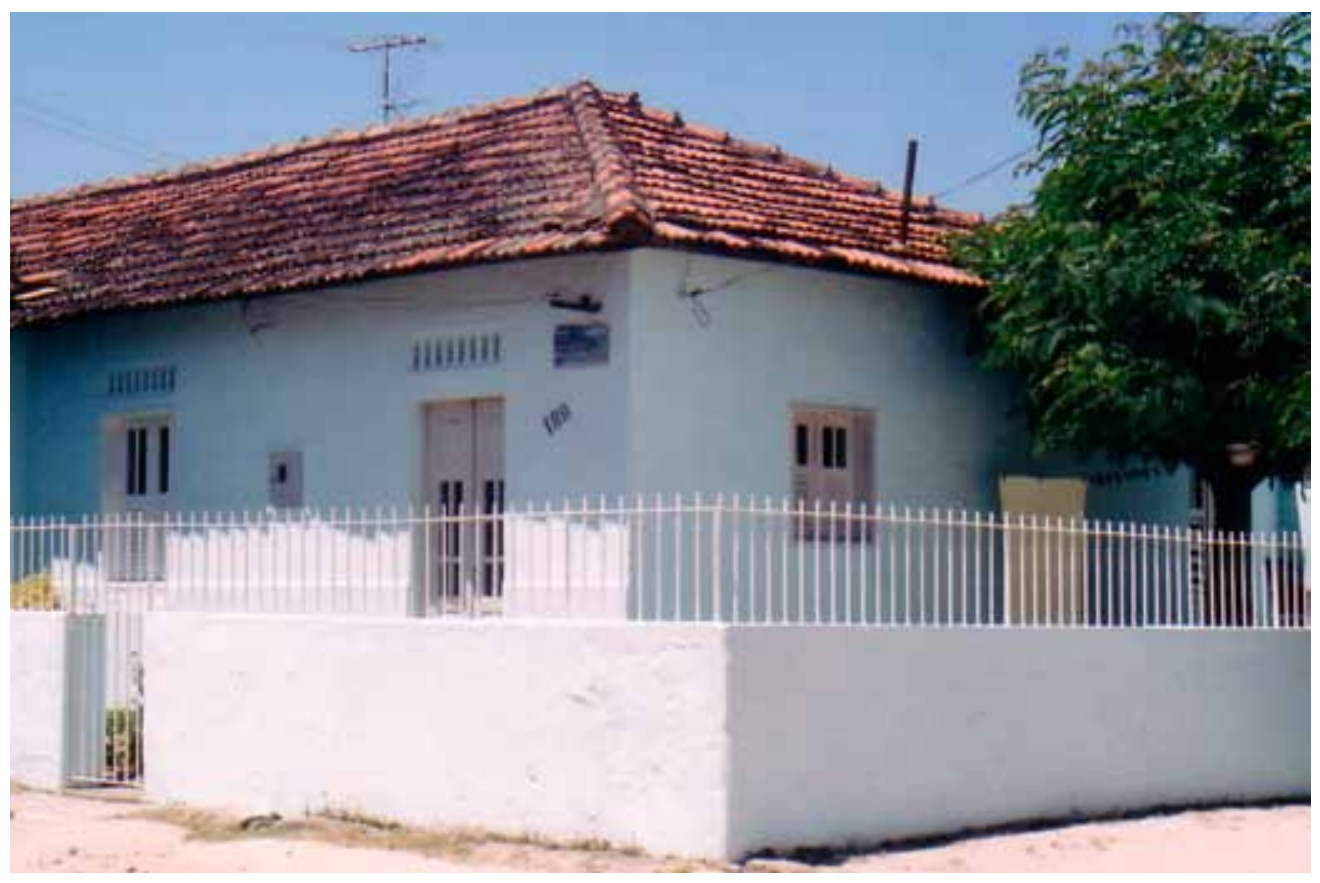

Figura 59 - Vila do Pombal, no Recife (PE). Fotografia de Philip Gunn, 1996. 


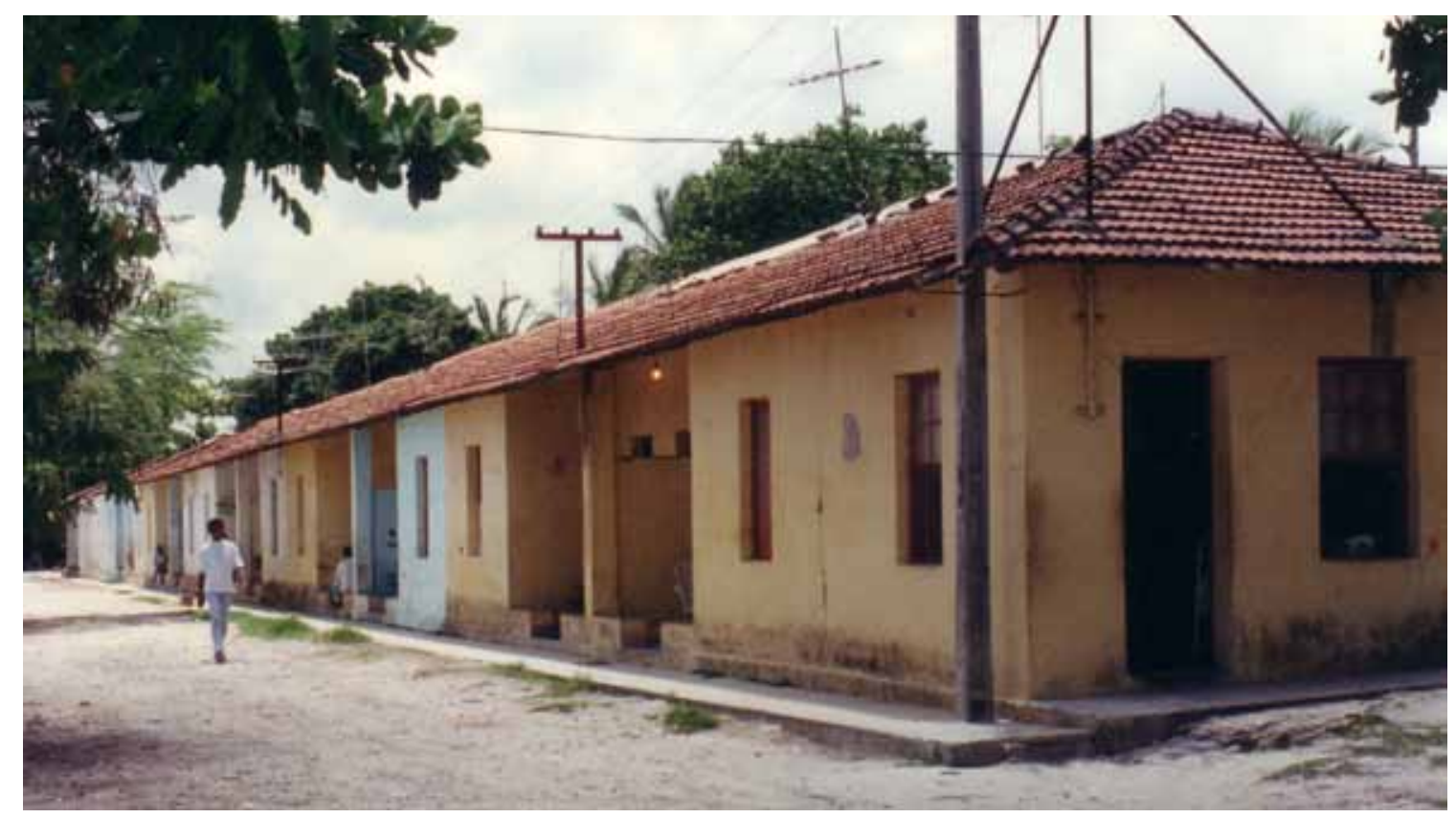

Figura 60 - Vila Poty, em Paulista (PE). Fotografia de Philip Gunn, 1996.

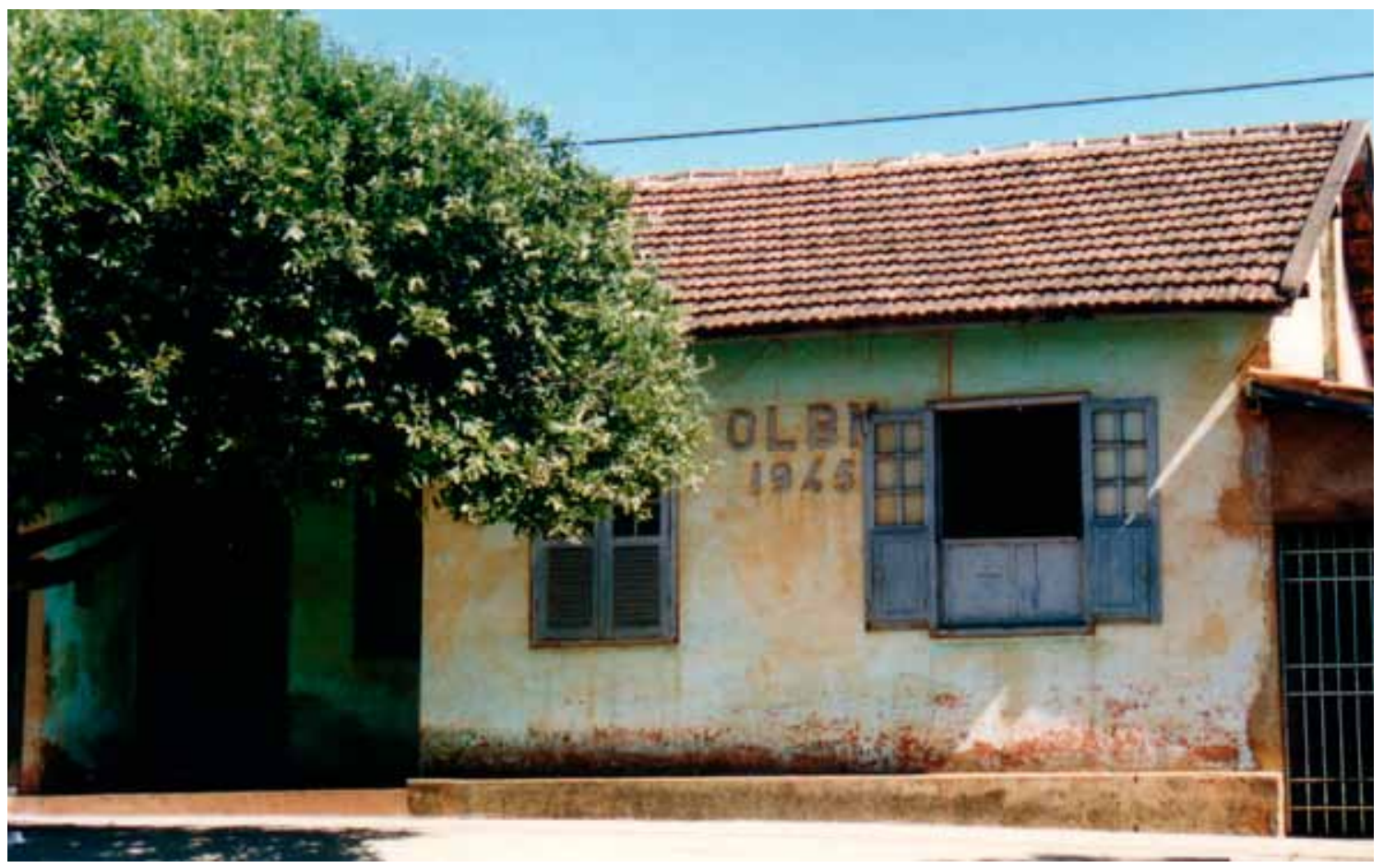

Figura 61 - Casas na vila operária da Fábrica Maria Amália, em Curvelo (MG). Fotografia de Philip Gunn, 1998. 


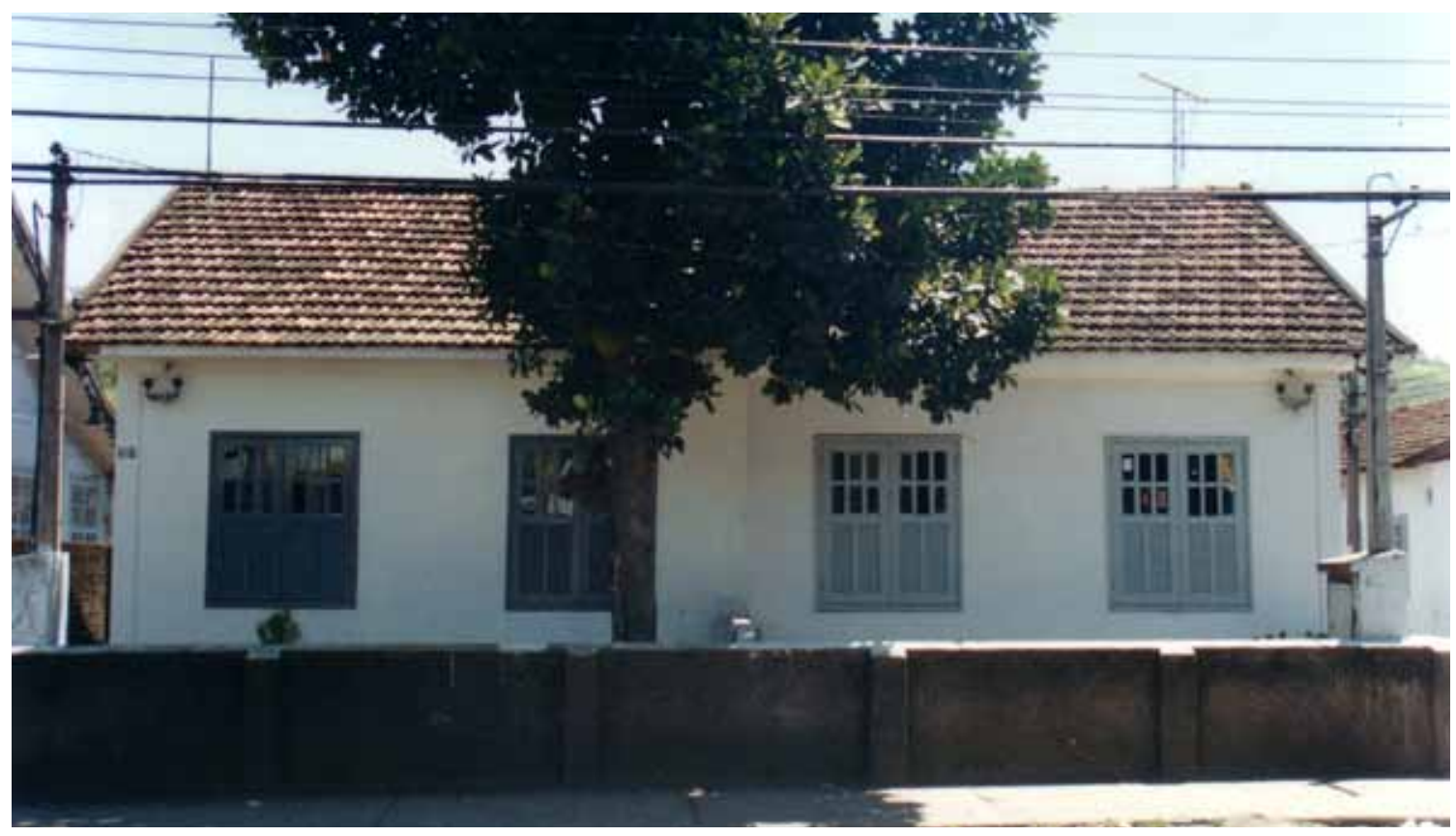

Figura 62 - Casas na vila operária da Siderúrgica Barra Mansa, em Barra Mansa (RJ). Fotografia de Philip Gunn, 2002.

48. A Vila Poty foi erguida pela Companhia de Cimento Portland Poty, do Grupo Votorantim, em Paulista (PE), a partir de 1942 de madeira que integra a escada e o estreito alpendre de acesso aos quartos do pavimento superior, onde estrutura e guarda-corpo em madeira adotam um desenho simples e extremamente econômico (Figura 63).

Como já mostrado, também nas igrejas e capelas ocorre a simplificação de formas e ornatos externos, e pode acentuar-se ainda mais, embora raramente ocorra de uma maneira suficientemente profunda a ponto de ocultar os signos da tipologia. Mesmo nos casos raros em que surgem destituídas de decoração externa, as destinadas ao culto permanecem, via de regra - ao lado das instalações fabris -, como as construções mais apuradas desses conjuntos. Estão quase sempre localizadas em pontos focais importantes - elevações, praças e/ ou extremidade de vias importantes -, compondo configurações expressivas. Nelas costuma ser mantido um vocabulário capaz de distinguir o uso: verticalidade, presença de uma ou duas torres, de vitrais, de óculos, de vãos em ogiva e/ou em arco pleno.

A igreja da Vila Poty ${ }^{48}$ é um desses casos onde a simplificação se radicaliza, apagando quase completamente os signos arquitetônicos da tipologia. A construção é destituída de indícios de requinte, seja em termos de composição, de tratamento das superfícies ou de concepção dos componentes. A torre, os vão em arco pleno e o pequeno óculo prestam-se, entretanto, para indicar o uso do prédio. Comparando esta igreja com a da Vila Santa Helena - já mencionada, e também erguida por fábrica de cimento do Grupo Votorantim -, é possível observar o procedimento de simplificação do projeto da igreja da Vila Poty: os óculos (de resto, excessivos) são reduzidos a um, assim como as torres; os ornatos 


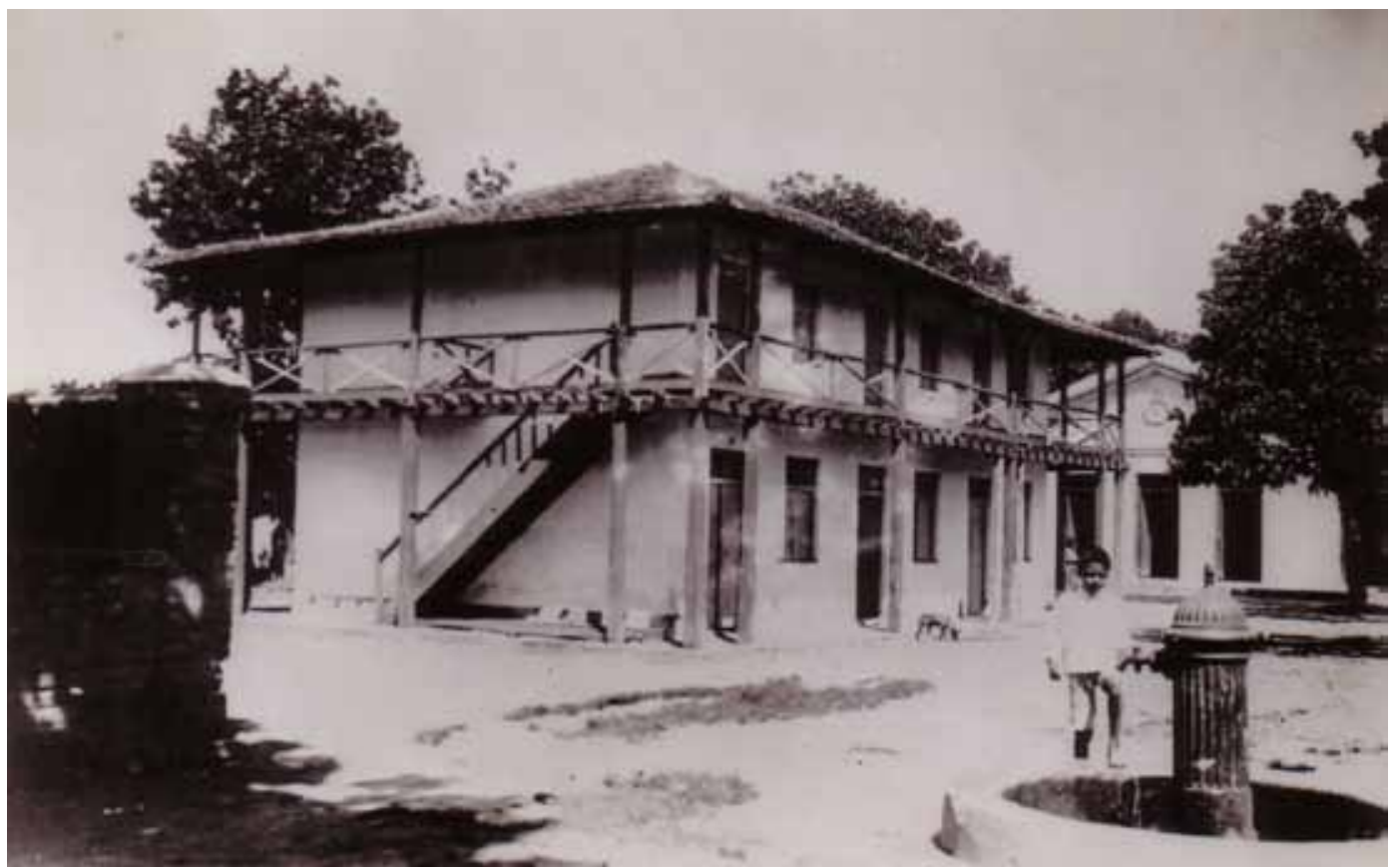

Figura 63 - Alojamento para solteiros erguido em Camaragibe (PE). Fonte: FUNDAJ.

são eliminados; o tamanho dos vãos (portas e vitrais) é reduzido, assim como o da própria igreja (Figura 64). Tal movimento de simplificação é ainda mais profundo no prédio que abriga a igreja da Fábrica Marituba, em Piaçabuçu (AL): se não fosse sua implantação, o pequeno sino que ostenta no alto da fachada principal, e os vãos em arco pleno dos basculantes das fachadas laterais, dificilmente teria seu uso reconhecido (Figura 65).

Entretanto, é na igreja da Vila Maria Amélia ${ }^{49}$ que a lógica fabril se expressa com maior nitidez. Nesse caso, o galpão que abriga o templo não incorpora qualquer característica que indique ser uma igreja. As seis portas largas, - letreiro no centro da fachada, e a marquise que percorre toda sua extensão sinalizam tratar-se de uma construção aberta a um público externo. A forma e a escala da construção, entretanto, assemelham-se às de uma loja, sugerindo um uso comercial. A cruz de ferro, muito discreta, é o único elemento que denuncia sua verdadeira função. $O$ viés utilitário desta construção é solidário com a lógica criticada por Charles Dickens em Tempos Difíceis, ao se referir à edificação de templos na "cidade do carvão":

Não se vê nada em Coketown que não seja fosse severamente referente ao trabalho. Se os membros de uma seita religiosa ali construíssem uma igreja [...], faziam-na como se fosse um pio depósito de tijolos vermelhos, encimada algumas vezes (mas apenas nos exemplos mais altamente ornamentais) por um sino dentro de uma espécie de abrigo de pássaros ${ }^{50}$.
49. Construída em 1944, em Curvelo (MG), pela Fábrica Maria Amália, do Grupo Othon.

50. Cf. Charles Dickens (1994, p. 19). 


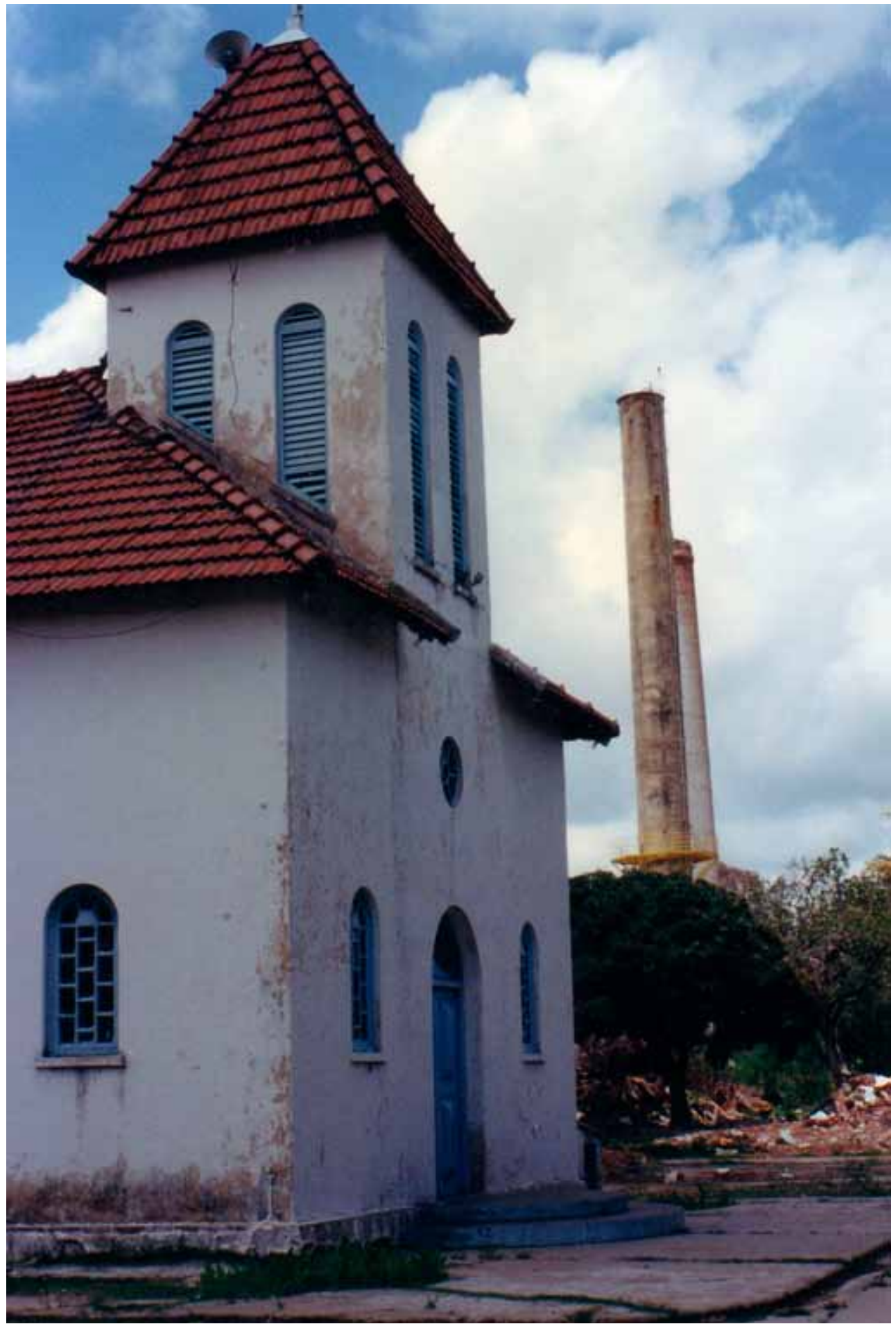

Figura 64 - Igreja da Vila Poty, em Paulista (PE). Fotografia de Philip Gunn, 1996. 


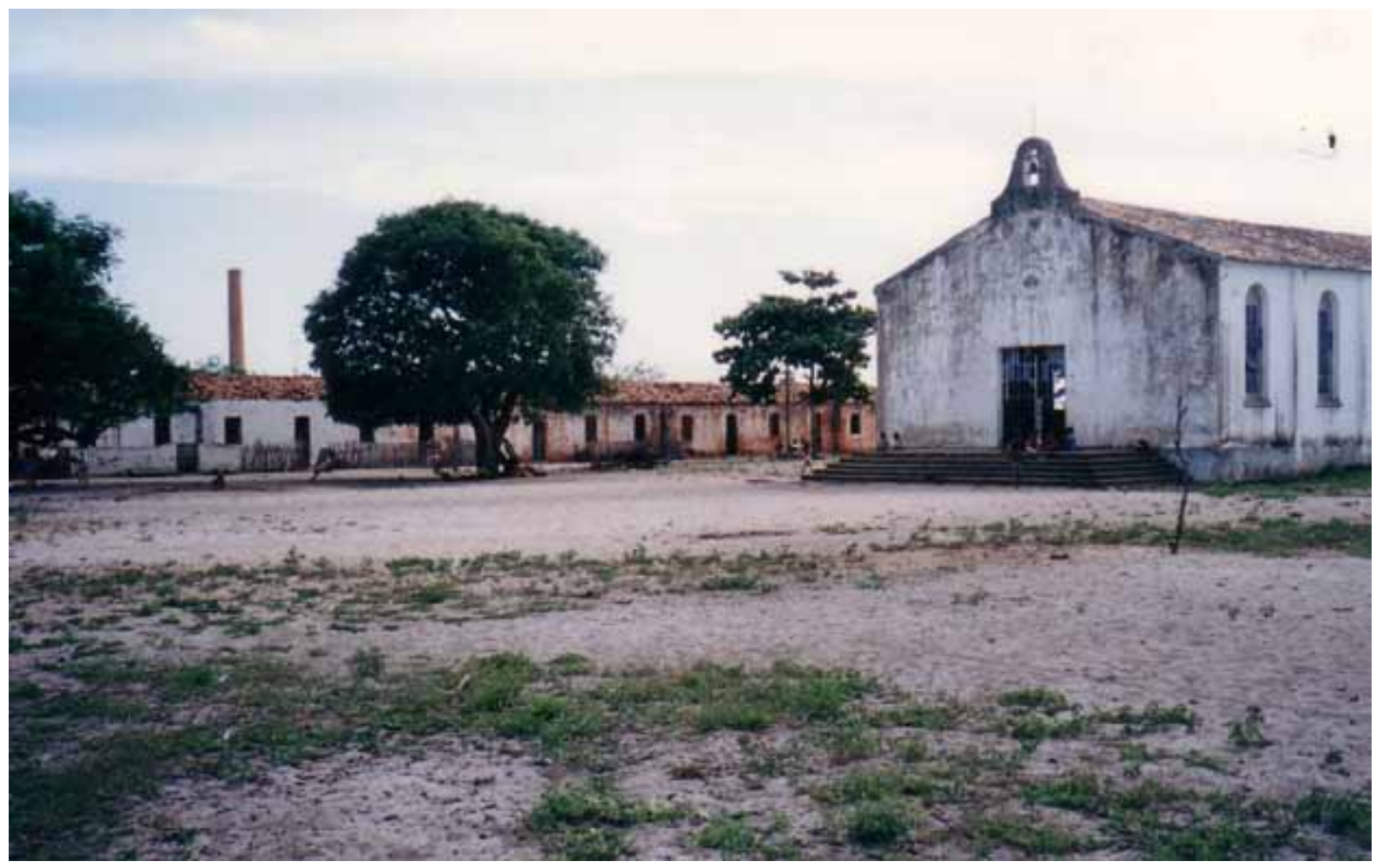

Figura 65 - Igreja da Fábrica Marituba, em Piaçabuçu (AL). Fotografia de Philip Gunn, 1994.

No caso da igreja da Fábrica Maria Amélia, ao "depósito" não restou nem sino nem arremedo de torre (Figura 66).

Tendências, influências e continuidades

Testemunhando o estreitamento das relações comerciais e culturais com os países industrializados, é possível identificar claramente, na forma das fábricas e dos núcleos fabris e vilas operárias analisadas, soluções que denunciam influências europeias, sobretudo inglesas, expressas em diversos aspectos. Um deles diz respeito às semelhanças entre prédios fabris e modelos ingleses, expressas em grandes fachadas em tijolo aparente, imensas chaminés, e uso do ferro nas estruturas de pisos e cobertas, embora se diferenciando desses modelos por limitar-se, usualmente, a um ou dois pavimentos. No que se refere às vilas e núcleos fabris, as aproximações com os modelos ingleses referem-se à difusão do uso de tijolo aparente; à ocorrência de sobrados inspirados nas tenement-houses lem Votorantim, em Marzagão, na Vila Boa Viagem, na Vila Boyes e na Vila Cerealina); às semelhanças entre os "quintalões" coletivos das vilas operárias da Brasital em Salto e os allotments dos núcleos fabris ingleses do final do século XIX 


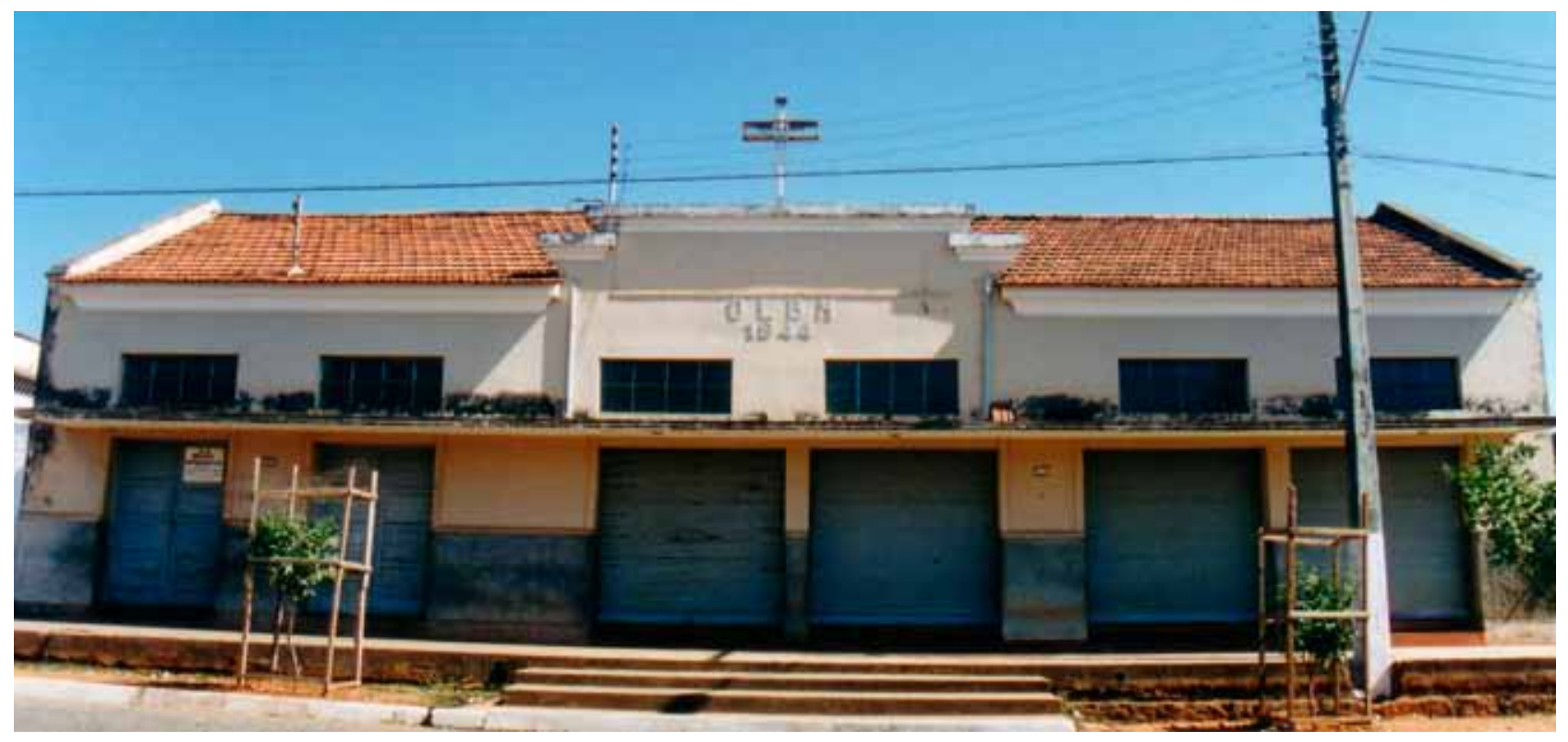

Figura 66 - Igreja da Vila Maria Amália, em Curvelo (MG). Fotografia de Philip Gunn, 1998.

e início do XX; e à adoção, em igrejas, de soluções que remetem a projetos britânicos do século XIX, baseados em motivos do gótico e do românico e na ideia de simplicidade.

Tais influências revelam-se com maior amplitude nos projetos de prédios fabris, muitas vezes elaborados por engenheiros vinculados, em grande parte, a firmas inglesas, como foi o caso das fábricas ligadas às vilas de Bangu, Boa Viagem, Maria Zélia e Brasital. No caso dos prédios voltados à vida não ligada diretamente ao trabalho, as semelhanças com modelos europeus evidenciam-se, sobretudo, nos exemplos (raros na época) de vilas operárias cujo projeto foi elaborado por engenheiros ou arquitetos, fossem brasileiros ou europeus, como a Vila Maria Zélia, a Vila Boa Viagem e a Vila Cerealina. Entretanto, as vias de contato com a Europa - e, em particular, com a Inglaterra - envolviam também viagens de industriais, em visita a fábricas e a exposições industriais, como testemunham os casos de Luis Tarquínio e Delmiro Gouveia, além dos intercâmbios desses industriais - que às vezes eram também engenheiros, como Carlos Alberto de Menezes - com indústrias europeias, e a vinda frequente de técnicos especializados europeus para trabalhar nas indústrias.

Um empecilho para uma avaliação mais precisa desses intercâmbios reside na dificuldade de localizar a autoria dos projetos arquitetônicos, assim como os próprios projetos. Nota-se que, em alguns projetos de fábricas, há indicações precisas da autoria; e suposições, no caso de outros. Já em relação às vilas e núcleos fabris, a localização da autoria dos projetos dos prédios erguidos no período em análise é muito rara. Tal dificuldade associa-se a diversos fatores. Em muitos casos as empresas e as construções não mais existem. Em núcleos fabris e em vilas operárias situadas em cidades pequenas, a maior parte 
das construções parece ter sido erguida sem projetos e sem necessidade de licença de construção. Pode-se ainda supor que a invisibilidade da autoria dos projetos esteja associada a uma desvalorização, do ponto de vista arquitetônico, desse tipo de produção. Sob o último aspecto, é curioso observar como eventualmente a imprensa da época ${ }^{51}$ descrevia detalhadamente plantas fabris - incluindo dados sobre o número de pavimentos, extensão das fachadas, pédireito, materiais e técnicas construtivas, assim como número de teares e de empregados etc. - sem, entretanto, fazer menção ao responsável pelo projeto e pela construção. Em tais casos, o interesse das matérias parece ser divulgar a fábrica e seus anexos enquanto realização técnica e empresarial, e não, como fato arquitetônico. Talvez esteja aí também uma das causas da pouca presença da arquitetura fabril nas revistas brasileiras, da época, especializadas em engenharia.

$\bigcirc$ limitado interesse que despertaram enquanto expressão arquitetônica entre seus contemporâneos provavelmente decorre da renovação da linguagem operada pelas construções vinculadas à indústria. Nelas, as inovações vão do programa e dimensão chegando ao atendimento de demandas funcionais e higienistas; do tratamento da alvenaria até à composição arquitetônica. Nas fábricas, as inovações construtivas e formais ampliam-se, com o eventual emprego de estruturas de ferro, iluminação zenital etc.

Um aspecto relevante de tal renovação diz respeito à difusão do uso do tijolo a vista, que se relaciona tanto à difusão do material na arquitetura dos países industrializados, quanto se apoia na produção em larga escala do material entre nós e, devido a ela, torna-se possível. No estado de São Paulo, essa ampla produção era propiciada por um grande número de olarias artesanais, por muitas fábricas e oficinas pequenas, e por algumas grandes indústrias de produção do materia $^{52}$. Aí, difunde-se e alcança prestígio o uso do tijolo aparente, associandose à arquitetura das grandes indústrias e de seus núcleos residenciais, e conquistando o gosto das elites. A aceitação do tijolo aparente pela elite paulista nas últimas décadas do século XIX é evidenciada não só por vários palacetes paulistanos com fachadas revestidas com o material ${ }^{53}$, mas também pelo seu emprego na residência do industrial Pereira Inácio em Votorantim.

Um dos aspectos centrais dessa renovação da arquitetura, que se evidencia naquela produzida pelas indústrias, diz respeito às diferentes vertentes do tratamento conferido aos ornatos e aos signos arquitetônicos tipológicos consagrados. Em uma delas, sobretudo nos prédios mais representativos existentes nos complexos industriais (fábricas, igrejas etc.), foi frequente a persistência de motivos ornamentais associados a estilos do passado e a mobilização, nas composições, do historicismo tipológico. Entretanto, se comparadas à produção eclética usual da época, é evidente, no âmbito fabril, o despojamento das construções de viés eclético, bem como a tendência, nessas construções, de superar os motivos ornamentais típicos desse movimento, trocando-os por formas mais simples e geométricas, às vezes referindo-se claramente ao mundo industrial.

Uma segunda vertente investe de forma resoluta na simplificação ou ausência de ornatos, assim como opera um maior distanciamento e, em casos
51. Tais descrições podem ser localizadas em vários periódicos como, por exemplo, Auxiliador da Indústria Nacional, Gazeta de Notícias e outros jornais locais.

52. Carlos Lemos mostra como, em São Paulo, o uso do tijolo foi impulsionado no século XIX por construções ligadas ao café, como o calçamento dos terreiros, os aquedutos etc. Sua produção se dava, sobretudo, de forma artesanal, em olarias acionadas manualmente que, a partir de 1867 , vão conviver com indústrias de produção de tijolos. A primeira olaria mecanizada de produção de tijolos em larga escala, segundo o autor, foi a pertencente a Sampaio Peixoto, instalada em 1867 em Campinas, à qual posteriormente se somaram outras, como a dos irmãos Sacoman e a Cerâmica São Caetano; cf. Carlos Lemos (1989, p. 40-43). Havia ainda uma série de pequenas fábricas e oficinas voltadas à produção do material; ver Paulo Cesar Xavier Pereira (2004).

53. Entre essas residências situam-se algumas projetadas por Ramos de Azevedo, como a casas de Cardoso de Almeida, na alameda Santos; Raphaela Paula Souza, na rua Florêncio de Abreu; Manoel Pessoa Siqueira Campos; Barão deArary; Cândido Moraes (construída em 1892); Condessa de Parnaíba (1891); Mello Oliveira (1892); Barbosa de Oliveira; e a residência do próprio Ramos de Azevedo, erguida entre 1889 e 1892 na rua Pirapitingui, no bairro da Liberdade; ver Maria Cristina Wolff de Carvalho (2000). 
extremos, abandona totalmente signos arquitetônicos tipológicos consagrados. De modo claro, a crescente redução de ornatos aponta para uma tendência à sua ausência total, como se observa no modelo de moradias operárias erguidas por fábricas e empresas de mineração que se firmou como um padrão nacional ao longo da primeira metade do século XX. Tal padrão de moradia foi a expressão de maior alcance da difusão de uma estética fabril no âmbito da arquitetura. Se, em termos formais, não foi a expressão mais instigante, foi certamente a de maior penetração, pelo impacto gerado na forma de morar de milhares de pessoas.

Essas tendências arquitetônicas tiveram desdobramentos posteriores. $\bigcirc$ tijolo aparente continuou a ser empregado, embora não mais com a mesma ênfase. $\bigcirc$ uso de ornatos inspirados em materiais e formas vinculadas ao mundo industrial teve continuidade na arquitetura de viés Art déco. Já o Estilo Internacional de arquitetura moderna haveria de consagrar a máquina como modelo de ordem, assim como o valor formal dos materiais produzidos em série. Também haveria de negar o ornato tradicional, deslocando o tratamento estético das construções para a composição volumétrica, o tratamento de superfícies com materiais diferenciados (pedra, azulejo, pastilha, tijolo aparente etc.), e a articulação da arquitetura com as artes plásticas e o paisagismo.

Estando a civilização industrial - com suas mudanças sociais, técnicas e econômicas - no cerne do movimento que gera o modernismo arquitetônico, não é de se estranhar que a arquitetura ligada a fábricas e a empresas de mineração tenha se antecipado na adoção de características importantes desta renovação da linguagem arquitetônica. Assim, se pode parecer inusitado embora não surpreendente - a veemência das citações às máquinas presentes na decoração de algumas das construções tratadas neste artigo ou o tratamento reservado pela Fábrica Maria Amélia à sua igreja, o mesmo não ocorre em face ao padrão de moradia operária funcional, despojado e enxuto que emerge nacionalmente com a indústria moderna.

\section{REFERÊNCIAS}

ANDRADE, Silvia M. B.Vilela de. Classe Operária em Juiz de Fora: uma história de lutas (19121924). Juiz de Fora: Editora UFJF, 1987.

BACKHEUSER, Everardo. Habitações populares. Relatório apresentado ao Exm. Sr. Dr. J. J. Seabra, Ministro da Justiça e Negócios Interiores. Rio de Janeiro: Imprensa Nacional, 1906.

BALZAC, Honoré de. A Comédia Humana, 2. ed. São Paulo: Globo, 1989.

BENCLOWICZ, Carla Milano. Prelúdio modernista. Construindo a habitação operária em São Paulo. 1989. Dissertação (Mestrado em Arquitetura e Urbanismo) - Faculdade de Arquitetura e Urbanismo, Universidade de São Paulo, São Paulo, 1989.

BLAY, Eva A. Eu não tenbo onde morar: vilas operárias na cidade de São Paulo. São Paulo: Nobel, 1985. 
BOMFIM, Suzete. A moradia do operário no Brasil. O caso da Vila Santa Cruz, Estância/SE. 2007. Dissertação (Mestrado em Arquitetura e Urbanismo) - Faculdade de Arquitetura e Urbanismo, Universidade de Brasília, Brasília, 2007.

CARDOSO, Luiz Antônio Fernandes. Entre vilas e avenidas: habitação proletária em Salvador, na Primeira República. 1991. Dissertação (Mestrado em Arquitetura e Urbanismo) - Faculdade de Arquitetura, Universidade Federal da Bahia, Salvador, 1991.

CARVAlHO, Maria Cristina Wolff de. Ramos de Azevedo. São Paulo: Edusp, 2000.

CORREIA,Telma de Barros. Pedra:plano e cotidiano operário no sertão. Campinas: Papirus, 1998.

O modernismo e o núcleo fabril: o anteprojeto de Lúcio Costa para Monlevade. Pós, São Paulo, n. 14, p. 80-93, 2003.

Núcleos fabris e de mineração no Brasil.As experiências pioneiras (1811-1880). Risco, São Carlos, v. 3, p. 15-42, 2006.

.Art déco e indústria, Brasil décadas de 1930 e 1940. Anais do Museu Paulista, São Paulo, v. 16, n. 2, p. 47-104, jul.-dez. 2008.

A indústria moderna no cenário clássico. Risco, São Carlos, v. 8, p. 69-101, 2009.

. A iniciativa privada e a transformação do espaço urbano e do território: Brasil, década de 1950. In: ENCONTRO NACIONAL DA ANPUR, 13. Anais... CD-ROM. Florianópolis: UFSC, 2010. 1 CD-ROM.

O pitoresco no mundo industrial: Ângelo Bruhns e a Vila Operária para a Companhia Commercio e Navegação. In: ENCONTRO NACIONAL DA ANPUR, 14. Anais... Rio de Janeiro: UFRJ; UFF, 2011. 1 CD-ROM.

CUSANO,Alfredo. Companhia Nacional de Tecido de Juta. Uma organização social ideal. In: MORAES FILHO, Evaristo de (Org.). Ideias sociais de Jorge Street. Cronologia, introdução, notas bibliográficas e textos selecionados. Ação e Pensamento da República. Brasília: Senado Federal; Rio de Janeiro: Fundação Casa de Rui Barbosa, 1980. p. 453-468.

DEAN, Warren. A industrialização de São Paulo (1880-1945). São Paulo: Edusp, 1971.

DIAS,Arthur. O Brazil actual. Rio de Janeiro: Imprensa Nacional, 1904.

DICKENS, Charles. Hard Times. London: Penguin, 1994.

DIXON, Roger; MUTHESIUS, Stefan. Victorian Architecture. London:Thames \& Hudson, 1995.

DUMÊT, Eliana Bittencourt. Luiz Tarquínio, o semeador de ideias. São Paulo: Gente, 1999.

FLETCHER, Banister. A History of Architecture 19th. London: Butterworths, 1987.

FUNDREM. Cascatinba: recuperação, revitalização. Rio de Janeiro: Fundação para o Desenvolvimento da Região Urbana, 1986.

Inventário dos bens culturais do município de Magé. Rio de Janeiro: Fundação para o Desenvolvimento da Região Metropolitana, 1984. 
GAZETA de Noticias, 20 nov. 1895.

GOMES, Geraldo.Arquitetura Eclética em Pernambuco. In: FABRIS,Annateresa. Ecletismo na Arquitetura Brasileira. São Paulo: Nobel; EDUSP, 1987

LEMOS, Carlos. Alvenaria burguesa: breve história da arquitetura residencial de tijolos em São Paulo a partir do ciclo econômico liderado pelo café. São Paulo: Nobel, 1989.

Ramos de Azevedo e seu Escritório. São Paulo: Pini, 1993.

MATOS, Maria Izilda Santos de. Trama e poder: a trajetória e polêmica em torno das indústrias de sacaria para o café (São Paulo, 1888-1934). 2. ed. Rio de Janeiro: Sette Letras, 1996.

MIGNOT, Claude. Architecture of the 19th century. Fribourg:Taschen, 1994.

MOREIRA, Danielle Couto. Arquitetura ferroviária e industrial: os casos de São João Del-Rei e Juiz de Fora (1875-1930). 2007. Dissertação (Mestrado em Arquitetura e Urbanismo) - Programa de Pòs-graduação em Arquitetura e Urbanismo, Escola de Engenharia de São Carlos, Universidade de São Paulo, São Carlos, 2007.

PANET,Amélia. Rio Tinto: história, arquitetura e configuração espacial. In: (Org.). Rio Tinto: estrutura urbana, trabalho e cotidiano. João Pessoa: Unipê Editora, 2002.

PEREIRA, Paulo Cesar Xavier. São Paulo, a construção da cidade, 1872-1914. São Carlos: Rima, 2004.

PINHO, Pericles Madureira de. Luiz Tarquínio. Pioneiro da Justiça Social no Brasil. Salvador: Imprensa Vitoria, 1944.

RAGO, Margareth. Do Cabaré ao lar: a utopia da cidade disciplinar. Brasil 1890-1930. 2. ed. Rio de Janeiro: Paz e Terra, 1987.

REYNOLDS, Jack. Saltaire. An introduction to the village of Sir Titus Salt. Bradford: Bradford Art Galleries and Museums, 1985.

ROLNIK, Raquel. Cada um no seu lugar! (São Paulo, início da industrialização: geografia do poder). 1981. Dissertação (Mestrado em Arquitetura e Urbanismo) - Faculdade de Arquitetura e Urbanismo, Universidade de São Paulo, São Paulo, 1981.

SAIA, Helena. Arquitetura e indústria. Fábricas de tecido de algodão em São Paulo, 1869/1930. 1989. Dissertação (Mestrado em Arquitetura e Urbanismo) - Faculdade de Arquitetura e Urbanismo, Universidade de São Paulo, São Paulo, 1989.

SAMPAIO, José Luis Pamponet. A evolução de uma empresa no contexto da industrialização brasileira: a Companhia Empório Industrial do Norte, 1891-1973. Dissertação (Mestrado em Ciências Humanas) - Faculdade de Ciências Humanas, Universidade Federal da Bahia, Salvador, 1975.

SCHORSKE, Carl. Pensando com a bistória: indagações na passagem para o modernismo. São Paulo: Companhia das Letras, 2000.

SERVICE,Alastair. Edwardian Architecture. London:Thames \& Hudson, 1977.

SILVA, Gracilda Alves de Azevedo. Bangu 100 anos: a fábrica e o bairro. Rio de Janeiro: Sabiá Produções Artísticas, 1989. 
STEIN, Stanley J. Origens e evolução da indústria têxtil no Brasil, 1850-1950. Rio de Janeiro: Campus, 1979.

STREET, Jorge. Inquérito sobre as relações industriais no Brasil (1937). In: MORAES FILHO, Evaristo de (Org.). Ideias sociais de Jorge Street. Cronologia, introdução, notas bibliográficas e textos selecionados.Ação e Pensamento da República. Brasília: Senado Federal; Rio de Janeiro: Fundação Casa de Rui Barbosa, 1980. p. 447-450.

SUMMERSON, John. A linguagem clássica da arquitetura. São Paulo: Martins Fontes, 1994.

TEIXEIRA, Palmira P. A fábrica do sonbo: trajetória do industrial Jorge Street. Rio de Janeiro: Paz e Terra, 1990.

VON DER WEID, Elizabeth; BASTOS, Ana Maria. O fio da meada: estratégia de expansão de uma indústria têxtil. Companhia América Fabril: 1878-1930. Rio de Janeiro: Fundação Casa de Rui Barbosa, 1986.

WERNECK, Bráulio (Org.). Almanach illustrado de Sorocaba. Sorocaba:Typographia Werneck, 1914.

ZEQUINI,Anicleide. O quintal da fábrica: a industrialização pioneira do interior paulista. Salto-SP, séculos XIX e XX. São Paulo:Annablume; Fapesp, 2004.

Artigo apresentado em 11/2010. Aprovado em 4/2011. 